\title{
O calcanhar de Aquiles dos estudos sobre crime, violência e dinâmica criminal
}

Ludmila Ribeiro ${ }^{1}$

Alex Niche Teixeira ${ }^{2}$

\section{Introdução}

Em seu texto intitulado "Avaliaçáo das ciências sociais”, publicado em 1993, Fábio Wanderley Reis reconstituiu a trajetória dos programas de pós-graduação na área que começaram a ser criados nos anos 1960 e 1970. Neste exercício, o autor ressalta como entre nós a preocupação em conhecer bem determinadas teorias náo reverberou em um aprimoramento metodológico de nossos pesquisadores, seja do ponto de vista quantitativo ou qualitativo. Partindo de uma perspectiva comparada, ele salienta como a nossa tradição, de formação humanística, levou-nos a um apego excessivo à teoria e à análise de fenômenos regionais, que seriam únicos em sua existência.

Segundo Reis (1993), nos Estados Unidos da América e Europa, a expansão das ciências sociais, desde uma perspectiva teórica, significou a preocupação com o teste de tais construtos, o que levou os programas de mestrado e doutorado de tais localidades a uma ênfase cada vez maior na análise de dados mais gerais, que cobrem boa parte da população (como os de survey). No Brasil essa proposta foi substituída pelo regionalismo, dado o entendimento de que é preciso conhecer profundamente uma realidade sobre a qual se fala. Tal traço náo seria muito discrepante, pelo menos comparado ao desenvolvimento das ciências sociais em países europeus, posta a extensão territorial e os aspectos culturais regionais. Porém, de forma concomitante, no Brasil, a ausência de cursos de metodologia que ensinassem os alunos a pensar em perguntas como "por quê?" em detrimento de "o quê?" contribuiu para que, historicamente, a produção da sociologia e da ciência política fosse alimentada por recortes muito mínimos, sem qualquer preocupação com a generalização, que permitissem o entendimento de padróes de causalidade desde uma perspectiva nacional.

O diagnóstico de Reis (1993) é bastante pontual: para avançar rumo a uma ciência social de cunho nacional, era preciso mudar. Mais do que narrar e interpretar a realidade social (o que é viabilizado por técnicas de pesquisa qualitativas), era preciso explicá-la em termos de relaçóes causais (o que seria possível por meio da incorporação de enquetes nacionais). Para torná-la nacional, era preciso incorporar dados representativos da população brasileira de forma a conhecer padróes mais gerais, sem tanta preocupação com o local.

1 É professora adjunta do Departamento de Sociologia (DSO) e pesquisadora do Centro de Estudos de Criminalidade e Segurança Pública (Crisp), ambos da Universidade Federal de Minas Gerais (UFMG). E-mail: ludmila.ribeiro@gmail.com

2 É diretor da Editora da Universidade Federal do Rio Grande do Sul (UFRGS), vice-presidente da Associação Brasileira das Editoras Universitárias (Abeu), professor adjunto do Departamento de Sociologia e do Programa de Pós-Graduaçáo em Sociologia da UFRGS e pesquisador associado ao Instituto Nacional de Ciência e Tecnologia sobre Violência, Democracia e Segurança Cidadá do CNPq e do grupo de pesquisa Violência e Cidadania da UFRGS/CNPq. E-mail: alex.teixeira@ufrgs.br 
Para a construção de teorias de médio alcance sobre as especificidades nacionais, era preciso ir além da revisão teórica.

É claro que o texto de Fábio Wanderley Reis se ocupava do balanço das ciências sociais, com destaque para a ciência política e sociologia. Além disso, foi escrito no início da década de 1990, antes dos programas de treinamento intensivo em metodologia, oferecidos por algumas universidades brasileiras ${ }^{3}$, quando nem mesmo os softwares de computador para auxílio à análise qualitativa de dados (como o Nvivo, Atlas.ti ou MAXQDA) ou de dados quantitativos (como o SPSS ou Stata) estavam amplamente disponíveis no mercado nacional. No entanto, podemos tomá-lo como ponto de partida para o escrutínio dos artigos enquadrados como "sociologia do crime, violência e dinâmica criminal", nome que em nossa perspectiva parece englobar os estudos que foram publicados nas revistas Qualis A1 e A2 da sociologia nos últimos anos ${ }^{4}$. Para nós, essa seara parece padecer hoje do mesmo problema apontado por Fábio Wanderley Reis, com pouca ênfase em pesquisas que sejam capazes de ir além da descrição do local, bloqueando o aprimoramento teórico e metodológico da área. Todavia, o caminho percorrido é bastante díspar em relação à trajetória das ciências sociais, como argumentaremos a seguir.

\section{Os balanços de literatura sobre crime: um olhar metodológico}

A sociologia do crime, violência e dinâmica criminal conta com cinco balanços de sua produção (ADORNO, 1993; BARREIRA; ADORNO, 2010; CAMPOS; ALVAREZ, 2017; LIMA; MISSE; MIRANDA, 2000; ZALUAR, 1999). Apesar de náo ser nossa proposta realizar um novo balanço temático, posto que o mais recente foi publicado há pouco (CAMPOS; ALVAREZ, 2017) e sim destacar quais são as técnicas de pesquisa de que os autores se utilizam em seus artigos, gostaríamos de salientar alguns pontos que nos parecem importantes para a compreensão de como metodologicamente essa área tem se estruturado.

Adorno (1993) foi o primeiro a inventariar a produçáo da área, que teria se iniciado a partir de finais da década de 1970, quando a criminalidade urbana se torna um problema público, demandando a atenção dos cientistas sociais. Neste primeiro diagnóstico, era crescente a quantidade de artigos publicados em congressos, livros e algumas revistas especializadas sobre a temática da criminalidade

3 Neste sentido, tem destaque o Programa de Treinamento em Metodologia Quantitativa (MQ) da Universidade Federal de Minas Gerais (disponível em: <https://bit.ly/2qwwLIv>), iniciado em 1998, e a IPSA summer school da Universidade de Sáo Paulo (disponível em: <https://bit.ly/1wkfZIP>), que acontece desde os anos 2010. Ambos são de periodicidade anual, sem qualquer interrupção desde os respectivos inícios. Três são as diferenças entre eles: o MQ é ministrado em português e acontece em julho; a summer school ocorre em janeiro e é todo ministrado em inglês; finalmente, o MQ oferece atualmente poucos cursos, em geral em métodos e técnicas de pesquisa quantitativos, enquanto a summer school oferece uma maior variedade de cursos, tanto quantitativos quanto qualitativos.

4 Aqui adotamos a perspectiva do último levantamento bibliográfico da área, realizado por Campos e Alvarez (2017, p. 143), os quais destacam que "embora a presente discussão busque circunscrever os estudos que originalmente foram caracterizados, no Brasil, como constituindo a área "sociologia da violência", muitos dos autores aqui citados possuem formação em antropologia e em ciência política, entre outras áreas afins. Na verdade, os estudos dessa temática no Brasil, a despeito da especialização crescente, continuam distribuídos amplamente no campo das ciências sociais, beneficiando-se, assim, da porosidade entre as fronteiras disciplinares dessa área do conhecimento". Assim, a preferência pelo enquadramento sociológico da análise está eminentemente relacionada à constituição histórica desse campo, à forma como ele próprio se denomina no âmbito da Associação Nacional dos Programas de Pós-Graduação em Ciências Sociais (Anpocs), além de ser essa a área temática dos demais levantamentos já realizados sobre o tema. 
e violência, a qual poderia ser organizada em quatro eixos temáticos. $\mathrm{O}$ primeiro tema foi denominado de "movimento da criminalidade" e consistia em análises quantitativas de dados oficiais, "mesmo considerando o comprometimento das fontes de informação" (ADORNO, 1993, p. 3), dado que a baixa confiança nas organizaçóes policiais poderia resultar em subnotificaçóes 5 e o padrão de operaçáo das polícias fazia com que pretos e pobres fossem mais registrados nas ocorrências criminais como autores do que os demais.

No segundo eixo estavam os trabalhos que diziam respeito ao "perfil social dos autores de delitos", estruturados a partir de análises quantitativas e qualitativas, que destacavam como os delinquentes eram "preferencialmente recrutados entre grupos de trabalhadores urbanos de baixa renda, o que significa que seu perfil social não difere do perfil social da população pobre" (ADORNO, 1993, p. 5). Longe de afirmar que os pobres seriam mais tendentes ao crime, o autor procurava destacar novamente a vulnerabilidade deste segmento às açôes implementadas pelo sistema de justiça criminal, tornando-os mais suscetíveis ao enquadramento jurídico como criminosos.

A terceira linha, denominada de "a organização social do crime sob a perspectiva do delinquente", estruturava-se a partir de etnografias realizadas por Alba Zaluar no Rio de Janeiro sobre "as peculiaridades da organização delinquente - seus modos de ser, seu estilo de vida, o relacionamento com os outros e com a sociedade mais ampla" (ADORNO, 1993, p. 5). Por fim, começava a despontar como temática crescente o escrutínio de "políticas públicas penais", dimensão na qual a observação participante, a análise dos documentos oficiais e a entrevista em profundidade desvendavam os estratagemas de operadores da segurança pública, da justiça criminal e do sistema prisional na atividade de transformaçáo da letra da lei em uma série de procedimentos que deveriam materializar a ideia de Justiça. Todas essas pesquisas salientavam como se dava a "aplicação cotidiana dos preceitos legais, que se tornam objeto de disputa e negociação entre diferentes atores que, enredados nas teias da moralidade, interpretam tais preceitos segundo interesses particulares e conforme as necessidades de funcionamento da organizaçấo" (ADORNO, 1993, p. 7).

Este primeiro balanço é de extrema importância porque, além de apontar os fundadores da área, os quais foram entrevistados por Lima, Azevedo e Ratton (2011) quase 20 anos depois, indica quais eram os caminhos que pareciam despontar como relevantes para o entendimento da dinâmica criminal em nosso país. Mais do que isso: trata-se de um balanço que, apesar de não destacar as técnicas de pesquisa utilizadas, permite que o leitor mais atento possa mapeá-las. Neste ponto chama atençáo a diversidade de estratégias metodológicas que os pesquisadores deste campo lançavam mão em comparação com os demais cientistas sociais brasileiros, já que os dois artigos - o de Fábio Wanderley Reis e o de Sérgio Adorno - são de 1993.

Se o texto de Reis (1993) salienta que a produção nacional era marcada pela reprodução teórica de autores internacionais sem lastro empírico, o estudo de Adorno (1993) mostra como a área de criminalidade se estruturava a partir de pesquisas. Enquanto Reis (1993) falava da pouca sofisticação metodológica, dada a colonização das ciências sociais por técnicas específicas da antropologia, como é o caso da etnografia, Adorno (1993) apontava para a diversidade de mecanismos que os sociólogos do crime, violência e dinâmica criminal

5 A última pesquisa nacional de vitimizaçâo (2012) indica que apenas $20 \%$ do total de crimes são comunicados à polícia. Nesse sentido, ver: <https://bit.ly/2qAqpJ5>. Último acesso em: 21 nov. 2017. 
se utilizavam, os quais incluíam técnicas de pesquisa qualitativas, quantitativas e mistas já nos anos 1980. Talvez, o único ponto em que os dois textos tenham algum tipo de convergência é o regionalismo, dado que mesmo as análises estatísticas eram circunscritas aos estados da regiáo Sudeste, mas novamente a sociologia do crime estava na frente, posta a sua preocupação em entender o local com o propósito de viabilizar a construção de novas teorias para melhor entendimento das especificidades nacionais.

Sendo a área da sociologia do crime, violência e dinâmica criminal tão diversa, em temas e estratégias de pesquisa, faz mesmo sentido aplicar a revisão de Reis (1993) sobre a fragilidade metodológica das ciências sociais brasileiras para o entendimento deste campo? Em que medida os estudos sobre criminalidade e violência se conformariam como uma seara na qual o dilema do calcanhar de aquiles se faz presente na atualidade?

Zaluar (1999) nos responde várias dessas questốes em seu balanço que, diferentemente do anterior, procura demarcar as conexóes teóricas e políticas dos sociólogos do crime. Para ela, os estudos sobre dinâmica criminal e funcionamento das organizações do sistema de justiça criminal cresciam vis-à-vis as transformaçōes políticas do país e, por isso, os autores destes textos estavam eivados da preocupação em descrever certos fenômenos como embasamento empírico para um posicionamento mais político. Era evidente, assim, como a sociologia do crime, violência e dinâmica criminal estava contaminada por uma perspectiva de formulação, implementação e avaliação de políticas públicas de prevenção e repressão ao crime, a qual determinaria sobremaneira os rumos da área nos anos subsequentes (FREITAS; RIBEIRO, 2014). Além disso, a autora destaca que, infelizmente, ao final de década de 1990, esse campo da sociologia já apresentava uma cisão metodológica decorrente de disputas teóricas, que colocavam em oposição os afeiçoados à estatística e os apegados à etnografia, como pode ser vislumbrado na seguinte citação:

\begin{abstract}
Ademais, a competiçấo entre os cientistas sociais e a delimitaçáo das fronteiras entre as disciplinas das ciências sociais, sempre táo problemáticas pelo seu estoque de conhecimento comum de teorias e pais fundadores, também sáo importantes para entender o debate [da sociologia do crime]. Essa disputa esteve particularmente clara entre os que sublinharam a importância dos indicadores sociais ou estatísticas oficiais sobre os crimes na formulação de uma política pública dissuasória e aqueles que, baseados em material qualitativo, chamavam a atenção para as práticas cotidianas dos policiais bem como para as condiçóes de vida existentes seja nas áreas onde viviam os candidatos à delinquência, seja nas prisōes (ZALUAR, 1999, p. 15).
\end{abstract}

Em outras palavras, Alba Zaluar já antevia a mudança que Campos e Alvarez (2017, p. 145) constataram quase vinte anos depois: os estudos de criminalidade passaram a se referir de tal maneira às políticas públicas a partir dos anos 2000, que melhor seria caracterizá-los como "políticas públicas de segurança, violência e punição no Brasil”. Como veremos nas próximas páginas, essa alteração de temáticas reverberou em mudanças do ponto de vista das técnicas de pesquisa mobilizadas. O dilema quantitativo versus qualitativo, estatísticas versus observação, foi substituído pela prevalência das entrevistas em profundidade, como forma de desvelar o que pensam os formuladores e as populaçóes afetadas por políticas públicas sobre o Estado.

A transmutação do paradigma metodológico não se deu apenas nos estudos sobre crime e violência. Como indicam os textos de balanço das perspectivas metodológicas nas ciências sociais, a tendência a relegar a estatística a segundo plano foi mais ampla. Contribuíram para esse padrão o lugar de pouco destaque que a formação metodológica tem nos cursos de ciências sociais (CANO, 2012) e a resistência à linguagem numérica, que náo pôde ser superada na sociologia 
(ao contrário do que parece ter acontecido com a ciência política), mesmo com os cursos de treinamento intensivo (NEIVA, 2015).

Em levantamento realizado por Gláucio Soares em 2005, o frágil treinamento em metodologia quantitativa foi apresentado como o calcanhar de aquiles das ciências sociais no Brasil. Para ele, haveria "uma certa hostilidade em relação aos métodos quantitativos e à estatística; porém, seu lugar não foi ocupado por métodos qualitativos rigorosos, e sim por uma ausência de métodos e de rigor" (SOARES, 2005, p. 27). Mais de uma década após o estudo original de Reis (1993), que identificava a carência de formação metodológica para que as ciências sociais tupiniquins pudessem ir além da revisão teórica ou da descrição de contextos muito específicos, o problema parecia um pouco pior: qualquer informação, coletada sem rigor, poderia ser nomeada de empiria, se tornando válida para teste de determinadas perspectivas teóricas.

Soares (2005) cita uma série de levantamentos realizados na área que demonstram o quão frágil seria o nosso treinamento metodológico, qualitativo e quantitativo, àquela época. Pior: as ciências sociais viam o quantitativo como algo imperialista (ao qual era preciso resistir) e compreendiam o qualitativo como o não quantitativo, esquecendo-se que existem técnicas de análise de dados qualitativas, como a observação participante, a entrevista em profundidade e, até mesmo, a etnografia. A gota d'água final seria, todavia, o colonialismo teórico, já que os construtos mobilizados eram os disponíveis em língua inglesa, tornando o pensamento sobre o Brasil estruturado "a partir de conceitos e categorias criados para descrever fenômenos de países industriais" (SOARES, 2005, p. 38), de pouca valia para a explicação de relaçôes de causa e efeito no contexto nacional. Combinando a deficiente formação metodológica com o colonialismo teórico, "o trabalho típico encontrado nas revistas brasileiras não é quantitativo, não é qualitativo, não é quali-quanti, é ensaístico" (Idem, p. 45).

Doze anos depois do texto de Fábio Wanderley Reis, as ciências sociais brasileiras continuavam essencialmente retóricas, o que impediria o diálogo com a realidade internacional, transformando distintas localidades pesquisadas no Brasil em somente mais um caso no espectro mundial. Ao simplesmente repetir perspectivas que já tinham sido traduzidas para o português, os cientistas sociais brasileiros se assemelhariam a jornalistas, que narram o que outros autores e sujeitos entenderam sobre como funcionam grupos ou indivíduos. Era preciso avançar, com uma preocupação em utilizar esses construtos como ferramentas para a melhor compreensão das semelhanças e especificidades da realidade nacional com outros contextos, o que demandaria maior sofisticação metodológica.

$\mathrm{Na}$ sociologia do crime, violência e dinâmica criminal, os anos 2000 foram marcados pela consolidação de grupos de pesquisa em todo o território nacional, em que pese a concentração desses na regiáo Sudeste (CAMPOS; ALVAREZ, 2017). Já no começo da década era possível identificar mais de 450 pesquisadores do tema, em diversas áreas do conhecimento, mesmo que as ciências sociais fossem a principal (Lima; Misse; Miranda, 2000, p. 46). Desde entáo, assistimos a uma profusão de análises que, para além de aspectos institucionais e culturais da violência, desvelam dimensôes mais vinculadas ao funcionamento do sistema de justiça criminal, com destaque para o peso que o crime organizado e o tráfico de drogas passaram a ter na explicação do aumento da criminalidade, sobretudo a violenta (Barreira; Adorno, 2010, p. 330).

Um tema que aparece na virada dos anos 2000 é a relação do Estado com as suas margens (Das; Poole, 2004), fazendo com que diversos pesquisadores passassem a descrever como são construídas cotidianamente as ilegalidades que marcam o imaginário popular sobre as periferias 
das grandes cidades (Telles; Hirata, 2010), levando ao entendimento de tais práticas como repositórios de mercadorias ilegais, "o que repercute na institucionalização e disseminação dos ilegalismos como práticas sociais não mais moralmente reprováveis (como, no passado recente, era para a "moral" da classe trabalhadora)" (Barreira; Adorno, 2010, p. 336). Neste ínterim, ganham notoriedade as externalidades do encarceramento em massa, a partir de artigos que relatam a disseminaçáo do modus operandi do grupo Primeiro Comando da Capital (PCC) para além dos muros dos estabelecimentos prisionais (Nunes, 2009), descrevendo os repertórios de justiça deste grupo (Feltran, 2010a), os quais passam, inclusive, a ser apontados como explicação para os processos sociais de vitimização prisional (Almeida; Paes-Machado, 2013).

Do ponto de vista metodológico, como apresentaremos a seguir, a área se tornou mais afeita a técnicas de pesquisa próprias da antropologia, como a etnografia e a observação participante, tornando imperativo conhecer bem as especificidades das regióes periféricas das grandes cidades, porque essa seria a maneira de subsidiar intervençôes qualificadas por parte das políticas públicas estatais. Na seara quantitativa, as dinâmicas de criminalidade se tornaram sinônimo dos padróes de registro das mortes violentas letais e intencionais, computadas pelas polícias ou calculadas a partir dos dados da saúde. A segurança pública passou a ser avaliada por deste indicador, tornando as pesquisas de vitimização e surveys de percepção de medo ou confiança nas instituiçóes recursos pouco mobilizados.

A preocupação em mudar o cenário fez com que vários pesquisadores trocassem a sala da universidade pelo gabinete do Executivo, ocupando cargos de destaque (como antecipado por Zaluar em 1999). Neste novo paradigma, era preciso agir, o que significa sacrifícios, como o de relegar a avaliação sobre a efetividade de políticas públicas a segundo plano (CANO;
ROJIDO, 2016). Essa metamorfose da área, colocada pela assunçáo do Brasil ao posto de um dos países mais violentos do mundo (LIMA; SINHORETTO, BUENO, 2015), pode ter contribuído sensivelmente para que os estudos quantitativos não desfrutassem da mesma importância que os qualitativos nessa área. Para quantificar em perspectiva nacional é preciso formaçáo sólida e engajamento de diversos centros, pesquisadores e financiadores, o que não ocorre com o qualitativo construído a partir do escrutínio da sociabilidade em um pequeno espaço das capitais brasileiras.

Todavia, movimento diverso foi observado nas ciências sociais nas últimas décadas. Em texto publicado em 2015, Pedro Neiva procura revisar o calcanhar de aquiles das ciências sociais. Ele argumenta que entre os anos de 1997 e 2012 teria ocorrido "um aumento expressivo na utilização de técnicas estatísticas" (NEIVA, 2015, p. 65), com destaque para as denominadas como "avançadas". No entanto, as conclusões do autor estavam longe de ser alvissareiras, dado que "a proporção de autores 'quantitativistas' continua sendo amplamente minoritária, vis-à-vis os 'não quantitativistas"' (Idem). Os ensaístas continuavam a ocupar posiçấo de destaque na produção global da área. Em outras palavras, o regionalismo (REIS, 1993) e o colonialismo teórico (SOARES, 2005) continuavam a contribuir para que a formação metodológica, especialmente a quantitativa, não estivesse na ordem do dia nos cursos de pós-graduação em ciências sociais (CANO, 2012).

Este cenário poder ser explicado pela formação acadêmica dos pesquisadores da área, centrada em autores em detrimento de perspectivas que pudessem ser transformadas em pesquisas empíricas (Ibid.). Isso faz com que uma parcela substantiva de alunos de pós-graduação, futuramente professores universitários, tenham "uma resistência injustificada por toda e qualquer evidência empírica, como se ela excluísse a discussão teórica” (NEIVA, 2015, p. 70). 
Fica, portanto, a pergunta sobre o que ocorreu na sociologia do crime, violência e dinâmica criminal do ponto de vista metodológico nos últimos anos. A nossa proposta aqui é entender o que mudou nessa área em termos de técnicas de pesquisa mobilizadas, se há ausência de estudos quantitativos e em que medida a pequena participação de trabalhos quantitativos se tornou o calcanhar de aquiles da área, como ocorre nas demais searas das ciências sociais (Ibid.).

\section{Metodologia $^{6}$}

Para a análise das estratégias metodológicas empregadas no estudo do crime e da violência foram consultadas todas as revistas classificadas no Qualis A1 e A2 da área de sociologia em 2016.

O Qualis foi um sistema criado pela Fundação Capes, do Ministério da Educação, com o objetivo de aferir a qualidade dos periódicos de cada área, a partir de comitês de notáveis em cada temática. Após análise de como se dá a escolha dos artigos a serem publicados pela revista e de qual é a visibilidade dessa produção, os journals são hierarquizados a partir de letras (A, B e C) e números ( 1 e 2 , no caso das revistas $A$; 1 a 5 , no caso das revistas $B$; e as revistas $\mathrm{C}$ não tem números) que equivalem, de certa maneira, ao prestígio que o periódico tem no campo ${ }^{7}$. Logo, centramos nosso foco nos periódicos qualificados como A1 e A2, porque esses seriam os mais prestigiosos da área e, por isso, com mais chances de serem lidos e usados como base de outros estudos, o que tende a reverberar em maior quantidade de citaçóes.

Pode acontecer de uma mesma revista ter qualificaçóes diferentes em duas ou mais áreas temáticas, o que é um problema para as ciências sociais, que incluem a sociologia, a ciência política e a antropologia. Em razáo dessa qualificaçáo diferenciada por área, optamos aqui por utilizar a avaliação dos periódicos feita pela sociologia para o quadriênio 2013-2016 ${ }^{8}$. Também especificamos a produçáo em língua portuguesa, para entender como os nossos pesquisadores expressam os resultados de seus estudos no contexto nacional. Com esse recorte, encontramos 49 revistas, 19 no estrato $\mathrm{A} 1$ e 30 no estrato $\mathrm{A} 2$.

Como quase todas as revistas A1 e A2 estão indexadas no portal SciELO ${ }^{9}$, que procura armazenar a produção de diversas áreas da ciência brasileira e padronizar as formas de apresentação dos artigos $^{10}$, a busca por aqueles relacionados ao estudo do crime, da violência e da dinâmica criminal se concentrou neste portal. A única exceção foi Dilemas, que não está indexada na SciELO. Nesse caso, recorremos ao site do periódico para identificação dos artigos.

Estabelecido o recorte e a fonte, nos meses de julho e agosto de 2017, por meio das ferramentas de busca do portal SciELO, entramos nas páginas de cada uma das revistas identificadas como A1 e A2 e, em seguida, procuramos pelas palavras "crime", "violência", "criminalidade" e "criminal". O próximo passo foi a leitura do resumo, pois não incluímos os artigos que tratam da violência desde uma perspectiva das relaçóes internacionais,

6 Os autores agradecem aos bolsistas de iniciação científica Gabriela Lacerda, Taís Santos e Tássio Almeida pela coleta de informaçóes no portal SciELO e pela organização dos dados primários deste artigo em uma planilha de Excel. Sem esses dados, as análises que seguem não seriam possíveis.

7 Nesse sentido, ver: <https://bit.ly/1Gygpnv>. Acesso em: 9 nov. 2017.

8 Disponível em: <https://bit.ly/1iK28d6>. Acesso em: 30 jun. 2017.

9 Segundo Neiva (2015, p. 79), “O simples fato de pertencer a essa coleção [SciELO] já indica uma qualidade superior do periódico".

10 Disponível em: <https://bit.ly/2ehncL0>. Acesso em: 9 nov. 2017. 
abordando, por exemplo, as guerras entre naçôes. Optamos por focalizar os trabalhos que versam sobre a violência no contexto brasileiro, incluindo todos os que, na nossa visão, se encaixavam com a temática do crime, da violência e da dinâmica criminal.

Antes de passarmos à análise dos dados propriamente dita, gostaríamos de apresentar três apartes. A primeiro diz respeito aos critérios de busca. As palavras-chave foram escolhidas considerando a forma como a área se estruturou historicamente (BARREIRA; ADORNO, 2010). Inicialmente, crime e violência eram as nossas únicas palavras-chave, sendo as mais representativas em nosso levantamento, responsáveis por 34,2\% e 31,6\% dos artigos analisados, respectivamente (Tabela 1 ). Com o decorrer da pesquisa no portal SciELO, constatamos que outras duas categorias também indexavam a produção: criminalidade e dinâmica criminal. A busca por "dinâmica criminal" foi problemática porque, apesar das aspas, eram incluídos artigos que tratavam de dinâmicas outras que não a criminal $\mathrm{e}$, por isso, optamos por incluir apenas "criminal".

\section{Tabela 1}

\section{Distribuição dos artigos identificados de acordo com as palavras de busca}

\begin{tabular}{lcc}
\hline $\begin{array}{c}\text { Palavra utilizada na } \\
\text { busca do artigo }\end{array}$ & Frequência & Porcentagem \\
\hline Criminalidade & 25 & 4,6 \\
\hline Criminal & 107 & 19,6 \\
\hline Crime & 187 & 34,2 \\
\hline Violência & 227 & 41,6 \\
\hline Total & 546 & 100 \\
\hline
\end{tabular}

Fonte: Elaborado pelos autores

Ao final foram reunidos 546 artigos, indexados pelas palavras "crime", "violência", "criminalidade" e "criminal". Destas, a que retornou um maior número de publicaçóes foi "violência", provavelmente por que ela indexa tanto as dinâmicas de criminalidade como as açóes desenvolvidas pelas agências estatais com vistas à prevenção e repressão do delito.

O segundo aparte diz respeito aos periódicos que não puderam ser incluídos por meio dessas palavras-chave. Pode acontecer de um artigo ser muito importante para a área e não estar indexado pelas palavras "crime", "violência", "criminalidade" e "criminal". Com isso, ele não foi identificado em nossa busca e, por conseguinte, não entrou nesta análise.

O terceiro aparte diz respeito ao período da coleta de dados e à data de publicação. A mineração dos artigos ocorreu entre os meses de julho e agosto de 2017 e, por isso, pode acontecer de um estudo ser referente, por exemplo, ao primeiro semestre de 2017, mas só estar disponível na SciELO ou no portal da revista Dilemas no segundo semestre. Nesse caso, ele não foi incluído em nossa base. Além disso, o portal SciELO foi criado em 1997 e, por isso, a produção por ele organizada tende a se referir a anos posteriores a esse marco $^{11}$. Por isso, pode acontecer de o periódico ter ingressado no portal SciELO, por exemplo, e náo ter transferido todas as publicaçóes anteriores a esse momento para $\mathrm{o}$ site e, dessa forma, em nossa busca, não foi possível identificá-las.

Considerando essas limitações, verificamos que a produçáo da sociologia do crime, violência e dinâmica criminal no portal SciELO tem como marco o ano de 1984 e cresce exponencialmente desde a década de 2000 (como indica a linha de tendência). Provavelmente, se o nosso levantamento tivesse sido realizado em março de 2018, a produção de 2017 teria superado a de 2016 (Gráfico 1).

11 Disponível em: $<$ https://bit.ly/2qtdatg>. Acesso em: 1 abr. 2018. 


\section{Gráfico 1}

\section{Distribuição da quantidade de artigos publicados por ano}

(1984 - $1^{\circ}$. Semestre de 2017)

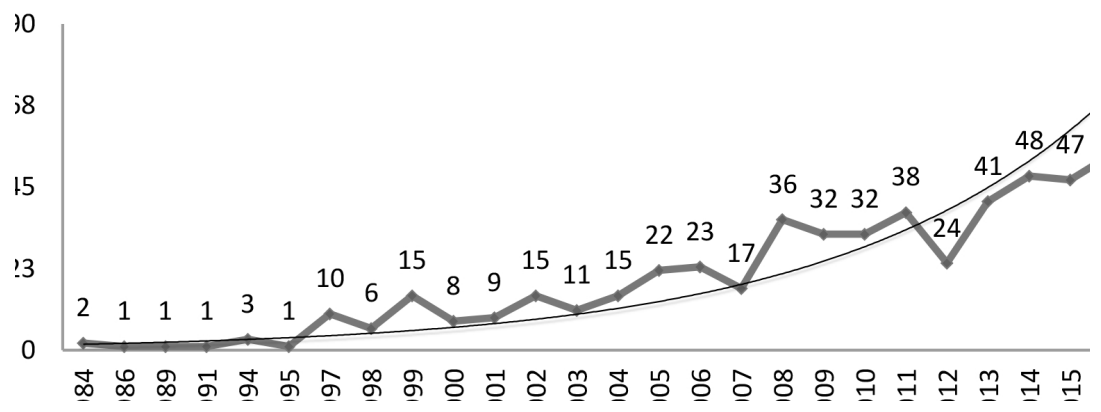

Fonte: Elaboração dos autores

Os poucos trabalhos levantados até o ano de 2000 contrastam com os balanços anteriores da área. Adorno (1993) computou 264 estudos para os anos entre $1972 \mathrm{e}$ 1993; Zaluar (1999) revisou 397 publicações entre 1974 e 1998; Kant de Lima, Misse e Miranda (2000) escrutinaram 1.166 estudos; e Barreira e Adorno (2010, p. 309) catalogaram "1.374 referências bibliográficas em 62 currículos constantes da Plataforma Lattes". Nesse contexto, 546 artigos parece um número excessivamente pequeno para um período de mais de 30 anos (1984-2017). Contudo, a contabilidade realizada por Adorno (1993), Zaluar (1999), Lima, Misse e Miranda (2000) e Adorno e Barreira (2010) considerava artigos publicados em anais de congresso, capítulos de livros, dissertaçóes e teses, sendo que esses trabalhos foram excluídos deste inventário, que considerou somente os artigos disponíveis em meio digital, na SciELO e nas revistas indexadas como A1 e A2 pelo Qualis da Capes ${ }^{12}$.

Outra explicaçáo para a diferença pode ser que as revistas indexadas pelo SciELO a partir dos anos 2000 não transferiram a sua produçáo anterior. Campos e Alvarez (2017, p. 148-149) levantaram 192 artigos publicados entre 2000 e 2016 nas revistas Lua Nova, Tempo Social, Novos Estudos Cebrap, Revista Brasileira de Ciências Sociais, Dados, Cadernos CRH, Sociedade e Estado, Sociologias, Civitas e Cadernos Pagu. Como nosso levantamento é quase três vezes maior - posto que inclui as 49 revistas em língua portuguesa situadas nos estratos A1 e A2 - possivelmente, apenas a produção digitalizada após a criação do SciELO em 1997 pôde ser adequadamente computada.

Das 49 revistas classificadas como A1 e A2 na área de sociologia, tão somente cinco náo apresentaram artigos indexados

12 Essa ressalva é importante porque, no portal da Capes, em março de 2017, Campos e Alvarez (2017, p. 145) identificaram no banco de teses e dissertaçōes da Capes "12.887 trabalhos contendo 'violência' como palavrachave; 3.898 trabalhos com a palavra-chave 'crime'; 2.200 com a palavra-chave 'criminalidade". Considerando esse balanço dos autores, seriam 18.985 trabalhos a serem catalogados, o que provavelmente inviabilizaria o exercício proposto neste trabalho. Além disso, acreditamos que os artigos na internet têm mais chances de serem lidos, o que tornaria a discussão metodológica mais relevante, posto que tal produção estaria mais acessível aos interessados no tema e, por conseguinte, teria mais chances de influenciar os demais interessados em termos de estratégias de pesquisa e análise de dados. 
pelas palavras "crime”, "violência”, “criminalidade" e "criminal". São elas: Revista de Administração Contemporânea (RAC), Revista Brasileira de Politica Internacional, Revista de Economia e Sociologia Rural, Revista Psicologia: Organizaçôes e Trabalho e Trans/Form/Ação, todas publicaçóes qualificadas como A2. Nas outras 44 revistas foi possível identificar 546 artigos (incluindo nessa categoria as resenhas e as apresentações de dossiês, mas descartando as entrevistas, homenagens, transcriçóes de aulas), sendo 306 publicados em revistas qualificadas como A1 e 240 nas revistas A2. Logo, a publicação dos trabalhos da sociologia do crime, violência e dinâmica criminal parece estar mais veiculada nos periódicos A1 do que nos A2 (56\% versus 44\%, respectivamente).

Em alguns periódicos foram encontrados poucos artigos (Tabela 2). Em outros, há enorme concentração da produção. A revista Dilemas, fundada ao final dos anos $2000 \mathrm{com}$ a proposta de publicar especificamente textos sobre conflito e controle social, concentrou 8,4\% da produção da área. A Tempo Social tem papel de destaque, reunindo $7,5 \%$ dos artigos mapeados, sendo um periódico que historicamente organizou dossiês sobre temas cadentes nas políticas públicas de segurança, como é o caso dos padróes de policiamento poucos condizentes com os princípios democráticos (CARDIA, 1997; MUNIZ et al., 1997; PAIXÃO; BEATO, 1997; PINHEIRO, 1997), da violência urbana como um problema público (ADORNO, 1998; GULLO, 1998) e, mais recentemente, sobre a sociologia das punições (ALVAREZ et al., 2013) e sobre o tráfico de drogas (ALVAREZ; FRAGA; CAMPOS, 2017). Além dessas duas revistas (Dilemas e Tempo Social), outras três são veículos prestigiados na divulgação dos estudos sociológicos sobre crime, violência e dinâmica criminal: Civitas (6,4\% dos artigos), Sociologias (6\%) e Sociedade e Estado (6\%).
Tabela 2

Quantidade de artigos identificados nas revistas Qualis A1 e A2 na área de sociologia (2013-2016) indexados pelas palavras "crime", "criminal", "violência" e "criminalidade"

\begin{tabular}{lcc}
\hline \multicolumn{1}{c}{ Nome do periódico } & Frequência & Porcentagem \\
\hline $\begin{array}{l}\text { Revista Brasileira } \\
\text { de Educação }\end{array}$ & 1 & 0,2 \\
\hline Revista História USP & 2 & 0,4 \\
\hline $\begin{array}{l}\text { Trabalho, Educaçáo } \\
\text { e Saúde }\end{array}$ & 2 & 0,4 \\
\hline Análise Social & 3 & 0,5 \\
\hline Cadernos CEDES & 3 & 0,5 \\
\hline Mana & 3 & 0,5 \\
\hline Novos Estudos Cebrap & 3 & 0,5 \\
\hline $\begin{array}{l}\text { Sociologia, Problemas } \\
\text { e Práticas }\end{array}$ & 3 & 0,5 \\
\hline Cadernos Metrópole & 4 & 0,7 \\
\hline Educação \& Sociedade & 4 & 0,7 \\
\hline Educaçáo e Realidade & 4 & 0,7 \\
\hline $\begin{array}{l}\text { Organizaçóes } \\
\text { \& Sociedade }\end{array}$ & 4 & 0,7 \\
\hline $\begin{array}{l}\text { Sociologia \& } \\
\text { Antropologia }\end{array}$ & 4 & 0,7 \\
\hline $\begin{array}{l}\text { Cadernos de Pesquisa } \\
\text { Fundação Carlos } \\
\text { Chagas) }\end{array}$ & 5 & 0,9 \\
\hline Relgo \& Socied & 5 & 0,9 \\
\hline
\end{tabular}

\begin{tabular}{lll}
\hline Religião \& Sociedade & 5 & 0,9 \\
\hline $\begin{array}{l}\text { Revista Brasileira de } \\
\text { Estudos de População }\end{array}$ & 5 & 0,9 \\
\hline $\begin{array}{l}\text { Revista Brasileira } \\
\text { de Sociologia }\end{array}$ & 5 & 0,9 \\
\hline $\begin{array}{l}\text { Revista Ciências } \\
\text { Sociais Unisinos }\end{array}$ & 5 & 0,9 \\
\hline Contemporânea & 6 & 1,1 \\
\hline Etnográfica [online] & 6 & 1,1 \\
\hline $\begin{array}{l}\text { História, Ciências, } \\
\text { Saúde }\end{array}$ & 6 & 1,1 \\
\hline $\begin{array}{l}\text { Horizontes } \\
\text { Antropológicos }\end{array}$ & 7 & 1,3 \\
\hline Estudos Feministas & 8 & 1,5 \\
\hline Opiniáo Pública & 8 & 1,5 \\
\hline Revista de Antropologia & 8 & 1,5 \\
\hline
\end{tabular}

(Continua) 
Tabela 2 - continuação

\begin{tabular}{|c|c|c|}
\hline Nome do periódico & Frequência & Porcentagem \\
\hline $\begin{array}{l}\text { Physis: Revista } \\
\text { de Saúde Coletiva }\end{array}$ & 8 & 1,5 \\
\hline Revista Direito GV & 9 & 1,6 \\
\hline $\begin{array}{l}\text { Dados: Revista de } \\
\text { Ciências Sociais }\end{array}$ & 10 & 1,8 \\
\hline $\begin{array}{l}\text { Lua Nova: Revista } \\
\text { de Cultura e Política }\end{array}$ & 11 & 2,0 \\
\hline $\begin{array}{l}\text { Psicologia: Teoria } \\
\text { e Pesquisa }\end{array}$ & 12 & 2,2 \\
\hline $\begin{array}{l}\text { Cadernos de Saúde } \\
\text { Pública }\end{array}$ & 14 & 2,6 \\
\hline $\begin{array}{l}\text { Revista de Saúde } \\
\text { Pública }\end{array}$ & 16 & 2,9 \\
\hline $\begin{array}{l}\text { Psicologia: Ciência } \\
\text { e Profissão }\end{array}$ & 18 & 3,3 \\
\hline Cadernos Pagu & 19 & 3,5 \\
\hline Caderno CRH & 20 & 3,7 \\
\hline $\begin{array}{l}\text { Revista Brasileira } \\
\text { de Ciências Sociais }\end{array}$ & 24 & 4,4 \\
\hline $\begin{array}{l}\text { Ciência \& } \\
\text { Saúde Coletiva } \\
\end{array}$ & 27 & 4,9 \\
\hline Psicologia \& Sociedade & 28 & 5,1 \\
\hline Saúde e Sociedade & 28 & 5,1 \\
\hline Sociedade e Estado & 33 & 6,0 \\
\hline Sociologias & 33 & 6,0 \\
\hline $\begin{array}{l}\text { Civitas - Revista } \\
\text { de Ciências Sociais }\end{array}$ & 35 & 6,4 \\
\hline Tempo Social & 41 & 7,5 \\
\hline Dilemas & 46 & 8,4 \\
\hline Total & 546 & 100 \\
\hline
\end{tabular}

Fonte: Elaborado pelos autores

Após selecionarmos todos os artigos de uma mesma revista, criamos uma pasta para cada periódico, baixamos os documentos em PDF e importamos para o Nvivo. Em seguida, começamos a fazer a análise de conteúdo.
Como destacado anteriormente, na revista "Dilemas", recorremos à página do periódico, mas encontramos problemas na ferramenta de busca: aparecem vários resultados - divididos em várias páginas - para cada palavra de busca, mas a seta que nos permite ter uma visão de todos os artigos encontrados náo funciona. Dessa forma, tivemos que abrir cada um dos artigos e ver quais eram as palavras a partir das quais eles estavam indexados, para então fazermos uma leitura minuciosa apenas dos referenciados por meio de nossos critérios.

Com a reuniáo de todos os artigos nas pastas, passamos à leitura dos mesmos, com vistas a entender quais eram os contextos pesquisados e as metodologias das quais os autores lançavam máo para o entendimento de cada problema de pesquisa. Inicialmente, foi possível reclassificá-los em 25 temas (Tabela 3), que apontam, em certa medida, na mesma direção do levantamento realizado por Campos e Alvarez (2017), dada a profusão de análises sobre o funcionamento da justiça criminal ( $10,9 \%$ dos artigos), das polícias $(8,4 \%)$ e do sistema prisional $(7,9 \%)$. Todavia, em nosso inventário, dois outros temas (re)aparecem como muito relevantes ${ }^{13}$ : i) padrōes de criminalidade (10,10\% das publicações), que são artigos muitas vezes construídos a partir do escrutínio dos dados oficiais, referentes aos Boletins de Ocorrência produzidos pelas organizaçôes policiais (BEATO; SILVA; TAVARES, 2008); e ii) violência contra a mulher ( $9,2 \%$ dos artigos), campo que vem tendo proeminência com a constituição de espaços específicos para atendimento deste tipo de violência, os quais ganharam maior visibilidade após a publicação da Lei Maria da Penha (AZEVEDO, 2008).

13 Tal diferença explica-se por Campos e Alvarez (2017) não terem consultado todos os periódicos A1 e A2 da área de sociologia, restringindo sua análise a dez revistas. Além disso, os termos de busca utilizados pelos autores foram muito mais diversos do que os nossos, englobando "violência”, "crime”, "criminalidade”, "puniçãa”, "prisão”, "polícia”, "justiça”, "justiça criminal”, "gênero", "mulheres”, "administraçẫo da justiça criminal”, "segurança pública” e "política de segurança pública”, retornando "196 artigos direcionados aos temas em questão" (p. 149). 


\section{Tabela 3}

Distribuição dos artigos catalogados de acordo com o tema principal de análise

\begin{tabular}{lcc}
\hline \multicolumn{1}{c}{ Temas principais } & Frequência & Porcentagem \\
\hline Criminologia \& música & 3 & 0,50 \\
\hline Tráfico de pessoas & 4 & 0,70 \\
\hline $\begin{array}{l}\text { Criminologia \& } \\
\text { cinema }\end{array}$ & 5 & 0,90 \\
\hline Familiares de vítimas & 5 & 0,90 \\
\hline Mulheres criminosas & 7 & 1,30 \\
\hline Representaçôes sociais & 7 & 1,30 \\
sobre crime & 8 & 1,50 \\
\hline Consumo de drogas & 9 & 1,60 \\
\hline Medo do crime & 9 & 1,60 \\
\hline Violência policial & 10 & 1,80 \\
\hline Criminosos & 11 & 2,00 \\
\hline Religiáo e crime & 11 & 2,00 \\
\hline Violência e escola & 13 & 2,40 \\
\hline Tráfico de drogas & 13 & 2,40 \\
\hline Violência contra & & \\
crianças e adolescentes & 21 & 3,80 \\
\hline Mídia e violência & 24 & 4,40 \\
\hline Direito penal & 30 & 5,50 \\
\hline Dinâmicas urbanas & 32 & 5,90 \\
\hline Violência e cultura & 33 & 6,00 \\
\hline Políticas públicas & 38 & 7,00 \\
\hline Juventude \& violência & 43 & 7,90 \\
\hline Sistema prisional & 46 & 8,40 \\
\hline Polícias & 50 & 9,20 \\
\hline $\begin{array}{l}\text { Violência contra a } \\
\text { mulher }\end{array}$ & 55 & 10,10 \\
\hline Padrôes de crime & 59 & 10,80 \\
\hline Justiça Criminal & 546 & 100,00 \\
\hline Total & & \\
\hline
\end{tabular}

Fonte: Elaborado pelos autores

Em nosso catálogo, outros cinco temas merecem destaque. Juventude e violência (7\% das publicaçóes), item que agrupa os estudos que descortinam as ociosidades (FRANCH, 2002), as sociabilidades (PIMENTA, 2014) e as masculinidades (MATTOS, 2014) que enredam os jovens na prática de delitos violentos (SENTO-SÉ; COELHO, 2014). As análises de políticas públicas (6\% dos artigos), que trabalham a efetividade de programas de prevenção (SILVEIRA, 2008), o arcabouço institucional herdado da ditadura (LIMA; SINHORETTO; BUENO, 2015) e como as novas mudanças significaram somente $o$ aumento do punitivismo e da quantidade de presos (AZEVEDO; CIFALLI, 2015), sem qualquer melhora mais substantiva nas taxas de criminalidade.

A categoria violência e cultura, que responde por 5,9\% dos artigos revisados, indexa vários dos estudos nacionais que têm uma perspectiva mais teórica. São trabalhos que procuram explicar como a nossa cultura contribui para a produção e reprodução de dinâmicas violentas (MISSE, 2008; SANTOS, 2002; SILVA, 2004; ZALUAR, 2009). As dinâmicas urbanas (5,5\%), por sua vez, conectam tanto os estudos sobre a gestáo de ilegalismos nas margens do estado (FELTRAN, 2010b) como aqueles referentes às diferentes sociabilidades que ocorrem nas áreas de favela da cidade maravilhosa (SILVA, 2010; ZALUAR, 2012a), como em outras grandes cidades brasileiras (BEATO; ZILLI, 2012). Por fim, o direito penal reúne $4,4 \%$ dos artigos, os quais destacam como se dá o processo de constituição do pensamento criminológico no Brasil (ALVAREZ, 2002; KOERNER, 2006) e como esse reverbera na edição de uma série de legislaçōes (POSSAS, 2015), inclusive as que procuram atualmente reduzir a maioridade penal (SANTOS, 2015), medida que não tem qualquer efeito sobre as taxas de criminalidade (LINS; FIGUEIREDO FILHO; SILVA, 2016).

Com essa revisão, até o momento, podemos confirmar o que os levantamentos anteriores já assinalavam: a produção da área de sociologia do crime, violência e dinâmica criminal cresceu nos últimos anos e se tornou mais diversificada, posto que, além de incluir a temática da criminalidade propriamente dita, passou a abarcar cada vez mais a análise de políticas públicas, padróes de policiamento, seletividade da justiça criminal e sistema prisional. 


\section{As perspectivas metodológicas}

Os 546 textos tiveram 407 primeiros autores diferentes, o que pode indicar elevada abertura da área a pesquisadores com múltiplos olhares sobre os objetos do crime, da violência e da dinâmica criminal ${ }^{14}$. Do ponto de vista metodológico, a sociologia do crime, violência e dinâmica criminal é, hoje, uma área essencialmente qualitativa, posto que $41,6 \%$ dos trabalhos se utilizam de alguma estratégia de análise qualitativa de dados náo estruturados, que incluem a etnografia, a entrevista em profundidade, o grupo focal e a observação participante. Neste item tem destaque - em termos de quantidade de artigos os estudos elaborados por Jacqueline Sinhoretto (2005, 2007, 2014, 2015), Sinhoretto, Silvestre e Melo (2013), Sérgio Adorno (1991, 1998, 1999, 2003), Patrícia Birman (2009, 2012) Birman e Machado (2012), Birman, Fernandes e Pierobon (2014) e Gabriel Feltran (2010a, 2010b, 2012, 2014).

Em segundo lugar estáo as revisóes teóricas, com $29,7 \%$ das publicaçóes catalogadas, tendo como objetivo o escrutínio da literatura nacional ou internacional para a melhor compreensão de um determinado contexto. Com esse desenho, sobrelevam Maria Stela Grossi Porto $(2000,2006,2009 a$, 2009b, 2015), com a teoria das representaçôes sociais aplicada ao campo da violência; Alba Zaluar, Noronha e Albuquerque (1994); Zaluar (1997, 2002, 2012b); e Zaluar e Barcellos (2013), com a categoria do ethos guerreiro para entendimento da prevalência masculina na prática e vitimizaçáo por homicídios nas periferias do Rio de Janeiro;
Michel Misse (2008, 2010a, 2010b, 2013, 2015), com a acumulação social da violência, que deu ensejo ao conceito de sujeição criminal; Machado da Silva (2004, 2010, 2011, 2015) e Silva e Leite (2007), com a problematização dos fatores históricos que levariam à sociabilidade violenta; José Vicente Tavares dos Santos $(1997,2002)$ e Santos e Teixeira (2013), com sua indagação sobre os processos civilizatórios e os usos da violência na contemporaneidade. É mister destacar que muitas vezes essa produção teórica faz referência a outros trabalhos, dos próprios autores, produzidos a partir de diversos dados qualitativos e quantitativos. Ocorre que nessas publicaçôes não há análise de dados propriamente dita, razão pela qual eles foram enquadrados como teóricos. Esses estudos são, ainda, fundamentais para entendimento da morfologia da área, posto que lançaram conceitos que são utilizados em diversos outros artigos deste mapeamento.

\section{Tabela 4}

\section{Distribuição dos artigos catalogados} de acordo com a metodologia utilizada

\begin{tabular}{lcc}
\hline \multicolumn{1}{c}{ Tipo de artigo } & Frequência & Porcentagem \\
\hline $\begin{array}{l}\text { Análise de dados } \\
\text { qualitativos } \& \\
\text { quantitativos }\end{array}$ & 64 & 11,7 \\
\hline $\begin{array}{l}\text { Análise de dados } \\
\text { quantitativos }\end{array}$ & 93 & 17,0 \\
\hline Teórico & 162 & 29,7 \\
\hline $\begin{array}{l}\text { Análise de dados } \\
\text { qualitativos }\end{array}$ & 227 & 41,6 \\
\hline Total & 546 & 100,0 \\
\hline
\end{tabular}

Fonte: Elaborado pelos autores

14 Seguimos aqui a mesma estratégia adotada por Neiva (2015, p. 71), que também considerou apenas os primeiros autores, por dois motivos. O primeiro é o fato de que a maioria dos artigos tem apenas um autor (no caso do nosso levantamento, $60,1 \%$ dos artigos têm autoria individual). "O segundo é que o eventual ganho analítico da inclusão dos coautores não compensaria os problemas decorrentes, sendo a duplicidade de informação (para um mesmo artigo) apenas um deles”. Neste cenário, o autor sugere considerarmos "o efeito da variável 'gênero', pois, nesse caso, interessa saber se algum deles é do sexo masculino". 
Em terceiro lugar aparecem os estudos quantitativos, com 17\% da produção catalogada. Trata-se de uma área encabeçada por Cláudio Beato Filho (1998), Beato Filho, Peixoto e Tavares (2004), Beato Filho, Silva e Tavares (2008), Gláucio Soares (2002), Soares e Miranda (2005a, 2005b), Renato Sérgio de Lima (2008), Lima, Sinhoretto e Bueno (2015), Lima, Bueno e Mingardi (2016), Joana Domingues Vargas (1999a, 1999b, 2007), Vargas e Rodrigues (2011), Ludmila Ribeiro (2010a, 2010b), Ribeiro, Machado e Silva (2012a, 2012b), Ribeiro et al. (2017) e Ribeiro e Duarte (2009). São autores que se dedicaram ao entendimento dos padróes de distribuição de crime e determinantes da vitimização, bem como à reconstituição do fluxo de procedimentos do sistema de justiça criminal pela via da contabilização de documentos e indivíduos.

Por fim, em quarto lugar está a produção ancorada nos mixed methods, com 11,7\% das mençóes, a qual procura entender determinados padróes de criminalidade (construídos a partir da análise quantitativa) com dados essencialmente qualitativos, resultantes da observação de dinâmicas de violência. Neste item, tem destaque a produção de Eduardo Paes Machado (2002a, 2002b, 2006, 2009, 2015), que procura compreender como sujeitos com características específicas terminam vítimas preferenciais de crimes violentos.

Quando comparamos a quantidade de artigos eminentemente teóricos com aqueles que contam com, pelo menos, algum tipo de análise de dados, verificamos uma dinâmica bem distinta em relação às ciências sociais em geral. Apesar dos estudos sobre crime, violência e dinâmica criminal contarem com uma grande quantidade de artigos eminentemente teóricos, a produção com algum tipo de análise empírica é maioria absoluta entre as publicaçóes. Ao longo dos anos 2000, essa área da sociologia tem mostrado que a melhor compreensão de porquê somos um dos países mais violentos do mundo ${ }^{15}$ demanda a observação de cenários, o melhor detalhamento das atividades desenvolvidas pelos profissionais de segurança pública e a apresentação dos padróes de crime e violência a partir dos registros policiais (Gráfico 2).

Embora a noção de colonialismo teórico não seja necessariamente superada pela prevalência de artigos com foco mais empírico, uma vez que a colonialidade do pensamento poderia se revelar nas matrizes analíticas destes dados, verificamos que a sociologia do crime, da violência e da dinâmica criminal tem se constituído a partir de estudos orientados para a análise de dados, em detrimento da revisão teórica, ao contrário do verificado em outras searas da sociologia (FREITAS; RIBEIRO, 2014). A grande questão que se coloca, portanto, é o tipo de empiria que marca essa produção. Afinal, como argumentado por Cano (2012, p. 100), o que confere legitimidade científica a determinada perspectiva explicativa da realidade "não é a sua origem, quem ou como a formulou, mas a forma como ela é validada empiricamente".

Quando analisamos somente a produção baseada na análise de dados, diferenciando-a em abordagens quantitativas, qualitativas e mistas (Gráfico 3), verificamos que no começo da série as três técnicas de análise de dados eram igualmente mobilizadas nos trabalhos de sociologia do crime, violência e dinâmica criminal. Nos últimos anos, todavia, temos uma prevalência dos estudos qualitativos, cuja quantidade, em termos de número de trabalhos, está bastante distante dos que se utilizam

15 De acordo com o último relatório das Naçôes Unidas sobre o tema. Nesse sentido, ver: United Nations Office on Drugs and Crime (2013). 
de estatísticas ou de desenhos mistos. Ao longo do tempo, a tendência ao uso de técnicas de pesquisa quantitativas e quali-quantitativas se mantém razoavelmente estável, com menos de dez artigos publicados por ano, enquanto as técnicas qualitativas experimentam um substancial acréscimo, ainda que decaindo no biênio 2016-2017.

\section{Gráfico 2}

\section{Distribuição dos artigos segundo enquadramento teórico versus análise de dados}

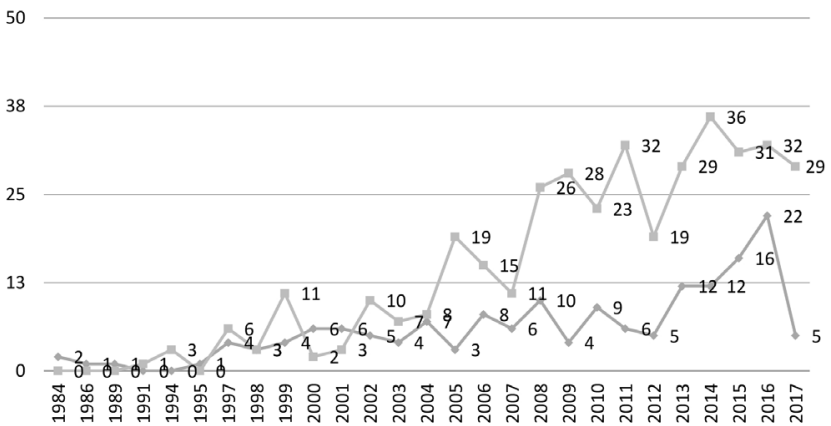

$\longrightarrow$ Teórica $\longrightarrow$ Análise de dados

Fonte: Elaborado pelos autores

\section{Gráfico 3}

\section{Distribuição dos artigos com alguma análise de dados, de acordo} com a metodologia empregada (quantitativa, qualitativa, mista)

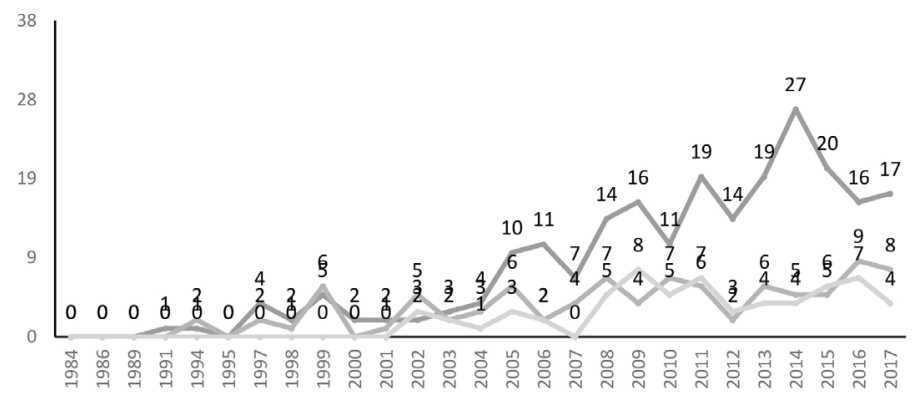

Fonte: Elaborado pelos autores

Diante desses dados, algumas indagaçóes sáo inevitáveis. Quais são as técnicas de pesquisa mobilizadas nos estudos da sociologia do crime, violência e dinâmica criminal? Quais são os temas mais associados aos estudos qualitativos e quantitativos? Em que medida a coautoria ou a instituição de origem poderia estar associada ao menor ou maior uso de determinadas abordagens metodológicas? O que pode explicar a predominância das análises de dados 
qualitativos em relação aos quantitativos? Essas são as perguntas que queremos responder.

Em seu artigo sobre as trincheiras do método, Ignacio Cano (2012) descreve as ciências sociais no Brasil como excessivamente fundamentadas na perspectiva retórica, privilegiando mais a formação intelectual do que a pesquisa empírica. Exatamente por isso, nossos estudantes saberiam pouco sobre os métodos de pesquisa em sociologia e, por conseguinte, teriam uma preferência pelas técnicas qualitativas, vistas como não uso do quantitativo, tal como argumentado por Soares $(2005)^{16}$. O problema é que "a escolha das técnicas a serem empregadas deve depender, em princípio, do tema da pesquisa e do contexto em que ela acontecerá, e náo da biografia ou das inclinaçôes do pesquisador. Nem todas as técnicas são adequadas para todos os projetos de pesquisa" (CANO, 2012, p. 106).

Organizando uma tabela que contrasta os 25 temas pesquisados com a técnica de pesquisa mobilizada, percebemos como alguns temas contam com mais análises quantitativas, como é o caso dos estudos sobre padrôes de crime, enquanto outros são mais teóricos, como ocorre nos classificados como violência e cultura ou aqueles que discutem como a teoria das representaçôes sociais pode ser aplicada para entendimento das justificativas mobilizadas pelos operadores do direito como causas da violência. Interessante notar que a maioria dos temas conta com algum tipo de análise qualitativa.

A técnica de pesquisa a ser mobilizada depende, em primeiro lugar, do objeto de estudo. Afinal, cientistas sociais, em tese, se interessam por aspectos da realidade social para depois escolherem a técnica de pesquisa que irão empregar para a compreensão do problema de pesquisa. Além disso, contribui para essa escolha a formação do pesquisador, o que amplia o seu leque de possibilidades: se o indivíduo não sabe analisar sequer uma tabela de frequência, dificilmente, ele irá escolher a abordagem quantitativa, preferindo a qualitativa. $\mathrm{O}$ fato de boa parte dos temas ser tratado a partir de análises qualitativas seria um indicativo de que estamos colonizados pelas técnicas de pesquisa próprias da antropologia, como a observação e a etnografia (REIS, 1993), ou o qualitativo tem ocupado o lugar do náo método (SOARES, 2005), dada a rejeição de nossos cientistas sociais a qualquer perspectiva mais quantitativa (CANO, 2012)?

Em princípio, a avantajada proeminência, em termos numéricos, de artigos que utilizam técnicas de pesquisa qualitativa - na maioria dos temas pesquisados - poderia nos informar sobre o ataque à generalizaçáo que o quantitativo pode gerar, tornando os autores de estudos que transformam sujeitos em números "responsáveis por criar uma realidade artificial que deixaria de lado a subjetividade e o sentido da ação" (Ibid., p. 114). Não se trata com isso de afirmar que a ausência de estudos mais quantitativos é, por si só, uma amostra do calcanhar de aquiles da sociologia do crime, violência e dinâmica criminal. O próprio texto de Ignacio Cano (Ibid.) nos propóe uma reflexão sobre os caminhos da ciência que construímos e não uma ode ao quantitativo, tendo em vista a inviabilidade de se conhecer determinadas realidades a fundo (como a moralidade que subjaz o comportamento dos membros de uma gangue) a partir de questionários estruturados, como acontece no caso das pesquisas de tipo survey. Trata-se, entâo, de entender o que interfere na escolha da técnica de pesquisa mobilizada pelos autores da área.

16 É bom lembrar que apesar de os termos "métodos" e "técnicas" de pesquisa serem usadas como sinônimos, existem diferenças marcantes entre eles. "Métodos seriam estratégias de produção de conhecimento científico, incluindo a geração e a validação de teorias. Técnicas seriam formas padronizadas de coleta e análise de dados, com a mesma finalidade, a de produzir conhecimento válido" (Ibid., p. 107). 
Tabela 5

Distribuição dos artigos mapeados por tema e técnica de análise de dados

\begin{tabular}{|c|c|c|c|c|c|c|}
\hline \multirow{2}{*}{ Tema } & & \multicolumn{4}{|c|}{ Abordagem metodológica } & \multirow{2}{*}{ Total } \\
\hline & & Teórica & Qualitativa & Quantitativa & Mista & \\
\hline \multirow{2}{*}{ Consumo de drogas } & $\mathrm{N}$ & 3 & 2 & 1 & 2 & 8 \\
\hline & $\%$ & $37,5 \%$ & $25,0 \%$ & $12,5 \%$ & $25,0 \%$ & $100,0 \%$ \\
\hline \multirow{2}{*}{ Criminologia \& cinema } & $\mathrm{N}$ & 0 & 5 & 0 & 0 & 5 \\
\hline & $\%$ & $0,0 \%$ & $100,0 \%$ & $0,0 \%$ & $0,0 \%$ & $100,0 \%$ \\
\hline \multirow{2}{*}{ Criminologia \& música } & $\mathrm{N}$ & 0 & 3 & 0 & 0 & 3 \\
\hline & $\%$ & $0,0 \%$ & $100,0 \%$ & $0,0 \%$ & $0,0 \%$ & $100,0 \%$ \\
\hline \multirow{2}{*}{ Criminosos } & $\mathrm{N}$ & 3 & 4 & 0 & 3 & 10 \\
\hline & $\%$ & $30,0 \%$ & $40,0 \%$ & $0,0 \%$ & $30,0 \%$ & $100,0 \%$ \\
\hline \multirow{2}{*}{ Dinâmicas urbanas } & $\mathrm{N}$ & 9 & 20 & 1 & 0 & 30 \\
\hline & $\%$ & $30,0 \%$ & $66,7 \%$ & $3,3 \%$ & $0,0 \%$ & $100,0 \%$ \\
\hline \multirow{2}{*}{ Direito Penal } & $\mathrm{N}$ & 21 & 2 & 1 & 0 & 24 \\
\hline & $\%$ & $87,5 \%$ & $8,3 \%$ & $4,2 \%$ & $0,0 \%$ & $100,0 \%$ \\
\hline \multirow{2}{*}{ Familiares de vítimas } & $\mathrm{N}$ & 0 & 5 & 0 & 0 & 5 \\
\hline & $\%$ & $0,0 \%$ & $100,0 \%$ & $0,0 \%$ & $0,0 \%$ & $100,0 \%$ \\
\hline \multirow{2}{*}{ Justiça criminal } & $\mathrm{N}$ & 9 & 29 & 10 & 11 & 59 \\
\hline & $\%$ & $15,3 \%$ & $49,2 \%$ & $16,9 \%$ & $18,6 \%$ & $100,0 \%$ \\
\hline \multirow{2}{*}{ Juventude \& violência } & $\mathrm{N}$ & 5 & 24 & 5 & 4 & 38 \\
\hline & $\%$ & $13,2 \%$ & $63,2 \%$ & $13,2 \%$ & $10,5 \%$ & $100,0 \%$ \\
\hline \multirow{2}{*}{ Medo do crime } & $\mathrm{N}$ & 6 & 3 & 0 & 0 & 9 \\
\hline & $\%$ & $66,7 \%$ & $33,3 \%$ & $0,0 \%$ & $0,0 \%$ & $100,0 \%$ \\
\hline \multirow{2}{*}{ Mídia e violência } & $\mathrm{N}$ & 4 & 13 & 1 & 3 & 21 \\
\hline & $\%$ & $19,0 \%$ & $61,9 \%$ & $4,8 \%$ & $14,3 \%$ & $100,0 \%$ \\
\hline \multirow{2}{*}{ Mulheres criminosas } & $\mathrm{N}$ & 0 & 5 & 0 & 2 & 7 \\
\hline & $\%$ & $0,0 \%$ & $71,4 \%$ & $0,0 \%$ & $28,6 \%$ & $100,0 \%$ \\
\hline \multirow{2}{*}{ Padróes de crime } & $\mathrm{N}$ & 2 & 4 & 39 & 10 & 55 \\
\hline & $\%$ & $3,6 \%$ & $7,3 \%$ & $70,9 \%$ & $18,2 \%$ & $100,0 \%$ \\
\hline \multirow{2}{*}{ Polícias } & $\mathrm{N}$ & 12 & 22 & 7 & 5 & 46 \\
\hline & $\%$ & $26,1 \%$ & $47,8 \%$ & $15,2 \%$ & $10,9 \%$ & $100,0 \%$ \\
\hline \multirow{2}{*}{ Políticas públicas } & $\mathrm{N}$ & 14 & 9 & 4 & 6 & 33 \\
\hline & $\%$ & $42,4 \%$ & $27,3 \%$ & $12,1 \%$ & $18,2 \%$ & $100,0 \%$ \\
\hline \multirow{2}{*}{ Religião e crime } & $\mathrm{N}$ & 2 & 8 & 1 & 0 & 11 \\
\hline & $\%$ & $18,2 \%$ & $72,7 \%$ & $9,1 \%$ & $0,0 \%$ & $100,0 \%$ \\
\hline \multirow{2}{*}{$\begin{array}{l}\text { Representaçóes sociais } \\
\text { sobre crime }\end{array}$} & $\mathrm{N}$ & 4 & 3 & 0 & 0 & 7 \\
\hline & $\%$ & $57,1 \%$ & $42,9 \%$ & $0,0 \%$ & $0,0 \%$ & $100,0 \%$ \\
\hline \multirow{2}{*}{ Sistema prisional } & $\mathrm{N}$ & 8 & 23 & 8 & 4 & 43 \\
\hline & $\%$ & $18,6 \%$ & $53,5 \%$ & $18,6 \%$ & $9,3 \%$ & $100,0 \%$ \\
\hline \multirow{2}{*}{ Tráfico de drogas } & $\mathrm{N}$ & 3 & 6 & 1 & 3 & 13 \\
\hline & $\%$ & $23,1 \%$ & $46,2 \%$ & $7,7 \%$ & $23,1 \%$ & $100,0 \%$ \\
\hline \multirow{2}{*}{ Tráfico de pessoas } & $\mathrm{N}$ & 2 & 2 & 0 & 0 & 4 \\
\hline & $\%$ & $50,0 \%$ & $50,0 \%$ & $0,0 \%$ & $0,0 \%$ & $100,0 \%$ \\
\hline
\end{tabular}


Tabela 5 - continuação

\begin{tabular}{|c|c|c|c|c|c|c|}
\hline \multirow{2}{*}{ Tema } & & \multicolumn{4}{|c|}{ Abordagem metodológica } & \multirow{2}{*}{ Total } \\
\hline & & Teórica & Qualitativa & Quantitativa & Mista & \\
\hline \multirow{2}{*}{ Violência contra a mulher } & $\mathrm{N}$ & 21 & 15 & 8 & 6 & 50 \\
\hline & $\%$ & $42,0 \%$ & $30,0 \%$ & $16,0 \%$ & $12,0 \%$ & $100,0 \%$ \\
\hline \multirow{2}{*}{$\begin{array}{l}\text { Violência contra crianças } \\
\text { e adolescentes }\end{array}$} & $\mathrm{N}$ & 3 & 6 & 3 & 1 & 13 \\
\hline & $\%$ & $23,1 \%$ & $46,2 \%$ & $23,1 \%$ & $7,7 \%$ & $100,0 \%$ \\
\hline \multirow{2}{*}{ Violência e cultura } & $\mathrm{N}$ & 27 & 5 & 0 & 0 & 32 \\
\hline & $\%$ & $84,4 \%$ & $15,6 \%$ & $0,0 \%$ & $0,0 \%$ & $100,0 \%$ \\
\hline \multirow{2}{*}{ Violência e escola } & $\mathrm{N}$ & 3 & 3 & 3 & 2 & 11 \\
\hline & $\%$ & $27,3 \%$ & $27,3 \%$ & $27,3 \%$ & $18,2 \%$ & $100,0 \%$ \\
\hline \multirow{2}{*}{ Violência Policial } & $\mathrm{N}$ & 1 & 6 & 0 & 2 & 9 \\
\hline & $\%$ & $11,1 \%$ & $66,7 \%$ & $0,0 \%$ & $22,2 \%$ & $100,0 \%$ \\
\hline \multirow{2}{*}{ Total } & $\mathrm{N}$ & 162 & 227 & 93 & 64 & 546 \\
\hline & $\%$ & $29,7 \%$ & $41,6 \%$ & $17,0 \%$ & $11,7 \%$ & $100,0 \%$ \\
\hline
\end{tabular}

Qui-quadrado: 312,306(0,000) $)^{17}$

Fonte: Elaborado pelos autores

Para Fábio Wanderley Reis (1993, p. 24), a forma de fazer pesquisa nas ciências sociais no Brasil estaria associada à "difusão do modelo 'antropológico' de trabalho", que privilegiaria o uso da etnografia e da observaçáo - direta ou participante - como principais técnicas de pesquisa, fazendo de todo o resto estratégias de compreensão da realidade que deveriam ser relegadas a segundo plano. $\mathrm{O}$ problema seria, portanto, o excesso de ênfase na descrição densa, como se apenas ela bastasse para a melhor compreensão dos problemas sociais. Afinal, se o texto se restringir a apresentar "uma curiosidade a mais no mundo de hoje, não trará nenhum aporte teórico" (PEIRANO, 2014, p. 383). Na tentativa de testarmos este argumento para a sociologia do crime, violência e dinâmica criminal contabilizamos se uma dada técnica de pesquisa foi ou não utilizada para a produçáo e análise de dados, razão pela qual um mesmo artigo pode estar em várias das categorias da Tabela 6 .
Tabela 6

\section{Distribuição dos artigos catalogados por tipo de técnicas de pesquisa mobilizadas para a análise (não excludente, um artigo pode usar mais de uma técnica)}

\begin{tabular}{lcc}
\hline \multicolumn{1}{c}{ Técnica de pesquisa } & N & \% \\
\hline Entrevista & 171 & $31,3 \%$ \\
\hline $\begin{array}{l}\text { Análise de dados oficiais } \\
\text { (dados do SIM/DATASUS } \\
\text { e Sistema de Segurança } \\
\text { e Justiça Criminal) }\end{array}$ & 111 & $20,3 \%$ \\
\hline Etnografia & 60 & $11,0 \%$ \\
\hline Observaçáo & 47 & $8,6 \%$ \\
\hline Survey & 42 & $7,7 \%$ \\
\hline Análise de conteúdo & 30 & $5,9 \%$ \\
\hline Estudos de caso & 23 & $4,2 \%$ \\
\hline Grupo focal & 20 & $3,7 \%$ \\
\hline
\end{tabular}

Fonte: Elaborado pelos autores

17 O teste qui-quadrado mede a independência de variáveis para verificar se há associação entre essas duas informaçōes. No entanto, não se pode estabelecer uma relação de causalidade, já que esse não é um teste apropriado para este tipo de finalidade. Ou seja, pode-se afirmar que os fenômenos estão relacionados, mas náo que um causa o outro necessariamente. 
De todos os estudos com análise de dados inventariados para este artigo, 11\% usam a etnografia e 8,6\% a observação como técnicas de pesquisa, o que indicaria um caminho distinto ao apontado por Reis (1993). Aparentemente, a antropologia náo nos colonizou. $\mathrm{Ou}$, pelo menos, não ainda.

A etnografia é a técnica sobre a qual paira a maior parte das críticas de Reis (1993), Soares (2005) e Cano (2012), posto que ela levaria a uma descrição densa sem maiores ambiçóes com a generalização. No entender de Peirano (2014), essa é uma compreensão um pouco equivocada dos métodos da antropologia, posto que uma boa etnografia significa uso de perspectivas teóricas e derivaçôes igualmente teóricas. Porém, a boa etnografia que Peirano (Ibid.) apresenta nem sempre é encontrada nos trabalhos que se valem dessa técnica para entendimento do crime, violência e dinâmica criminal com excessiva ênfase na descrição sem preocupação com a abstração que deveria ser gerada ao final (FREITAS; RIBEIRO, 2014). Estaríamos, talvez, naquilo que Soares (2005) denomina como não método: uma descrição pelo detalhamento, sem a preocupação com a validação de paradigmas teóricos.

A abordagem preferencial para a geração de informaçôes sobre crime, violência e dinâmica criminal é a entrevista (31,3\%), cujas respostas podem ser transcritas nos estudos qualitativos, transformadas em tabelas de frequência nos estudos de cunho quantitativo ou empregadas para entendimento de padróes mais gerais, encontrados nos estudos de natureza mista. Entre as técnicas de pesquisa qualitativa, a observação direta ou participante respondeu por $8,6 \%$ dos trabalhos analisados; a análise de conteúdo, empregada para o escrutínio de notícias de jornais e documentos judiciais, gerando informaçóes que podem ser exploradas tanto qualitativamente como quantitativamente, foi utilizada em 5,9\% dos artigos mapeados.
Entre as técnicas próprias da análise de dados quantitativa, o escrutínio dos bancos de dados cedidos pelas organizaçóes que compóem o sistema de segurança pública e justiça criminal, bem como as informações organizadas pelo sistema de mortalidade (SIM/ DATASUS), despontam com proeminência, estando presentes em boa parte dos estudos mistos. Em seguida, há o survey, que consiste na "aplicação de questionários a uma amostra da população" (CANO, 2012, p. 14), mobilizada em 7,7\% das publicaçóes catalogadas.

A Tabela 6 revela a preferência por técnicas de pesquisa que permitem capturar o discurso de certas comunidades, sujeitos que ocupam funçôes públicas ou ainda indivíduos que praticam ilegalismos, mas também um uso bastante intenso dos bancos de dados das instituiçóes públicas. O diagnóstico de Cano (Ibid.) é que isso acontece porque os profissionais, quando estudantes, não são adequadamente formados em técnicas de pesquisa variadas, se tornando presas fáceis de algumas abordagens metodológicas em detrimento de outras, o que dificultaria a construção de desenhos que incluem, por exemplo, a aplicação de questionários do tipo survey.

Se não estamos dominados completamente pelos métodos da antropologia, apesar de ela ter cadeira cativa na sociologia do crime, violência e dinâmica criminal, o rechaço ao uso de técnicas quantitativas (mobilizadas total ou parcialmente em 29\% dos artigos mapeados) faz com que a preferência pela particularidade se sobressaia a abordagens nacionais. Afinal, ninguém pensa em revelar os padróes de criminalidade no Brasil a partir de etnografias em todos os mais de 5.500 municípios que possuímos. O problema seria o rechaço ao quantitativo e, assim, "enquanto os cientistas sociais se autolimitam deliberadamente, o espaço é ocupado por economistas, por engenheiros ou arquitetos em temas urbanos, por epidemiologistas em temas de saúde e 
por outros profissionais com menos preconceitos metodológicos” (Ibid., p. 26). Tal argumento ajuda a compreender a prevalência da abordagem quantitativa nos periódicos Cadernos de Saúde Pública e Revista de Saúde Pública, os quais contam com mais de 90\% dos artigos catalogados para este estudo estruturados a partir de análises estatísticas, mesmo que complementadas com algum tipo de análise qualitativa (Tabela 7).

Tabela 7

Percentual de artigos com análise estatística (isolada ou combinada com dados qualitativos) por revista

\begin{tabular}{|c|c|c|c|c|c|}
\hline \multirow{3}{*}{ Nome do periódico } & \multicolumn{4}{|c|}{ Uso de dados estatísticos } & \multirow{3}{*}{ Total } \\
\hline & \multicolumn{2}{|c|}{ Sim } & \multicolumn{2}{|c|}{ Não } & \\
\hline & $\mathbf{N}$ & $\%$ & $\mathbf{N}$ & $\%$ & \\
\hline Análise Social & 0 & $0 \%$ & 3 & $100 \%$ & 3 \\
\hline Cadernos CEDES & 0 & $0 \%$ & 3 & $100 \%$ & 3 \\
\hline Cadernos Pagu & 0 & $0 \%$ & 19 & $100 \%$ & 19 \\
\hline Direito $G V$ & 0 & $0 \%$ & 9 & $100 \%$ & 9 \\
\hline Educação \& Sociedade & 0 & $0 \%$ & 4 & $100 \%$ & 4 \\
\hline Etnográfica [online] & 0 & $0 \%$ & 6 & $100 \%$ & 6 \\
\hline História, Ciências, Saúde & 0 & $0 \%$ & 6 & $100 \%$ & 6 \\
\hline Lua Nova: Revista de Cultura e Politica & 0 & $0 \%$ & 11 & $100 \%$ & 11 \\
\hline Mana & 0 & $0 \%$ & 3 & $100 \%$ & 3 \\
\hline Religiāo \& Sociedade & 0 & $0 \%$ & 5 & $100 \%$ & 5 \\
\hline Revista Brasileira de Educação & 0 & $0 \%$ & 1 & $100 \%$ & 1 \\
\hline Revista Brasileira de Sociologia & 0 & $0 \%$ & 5 & $100 \%$ & 5 \\
\hline Revista História USP & 0 & $0 \%$ & 2 & $100 \%$ & 2 \\
\hline Sociologia \& Antropologia & 0 & $0 \%$ & 4 & $100 \%$ & 4 \\
\hline Sociologia, Problemas e Práticas & 0 & $0 \%$ & 3 & $100 \%$ & 3 \\
\hline Revista de Antropologia & 1 & $13 \%$ & 7 & $88 \%$ & 8 \\
\hline Physis: Revista de Saúde Coletiva & 1 & $13 \%$ & 7 & $88 \%$ & 8 \\
\hline Horizontes Antropológicos & 1 & $14 \%$ & 6 & $86 \%$ & 7 \\
\hline Caderno CRH & 3 & $15 \%$ & 17 & $85 \%$ & 20 \\
\hline Psicologia: Teoria e Pesquisa & 2 & $17 \%$ & 10 & $83 \%$ & 12 \\
\hline Cadernos de Pesquisa (Fundação Carlos Chagas) & 1 & $20 \%$ & 4 & $80 \%$ & 5 \\
\hline Revista Ciências Sociais Unisinos & 1 & $20 \%$ & 4 & $80 \%$ & 5 \\
\hline Sociologias & 7 & $21 \%$ & 26 & $79 \%$ & 33 \\
\hline Psicologia: Ciência e Profissão & 4 & $22 \%$ & 14 & $78 \%$ & 18 \\
\hline Civitas & 8 & $23 \%$ & 27 & $77 \%$ & 35 \\
\hline
\end{tabular}


Tabela 7 - continuação

\begin{tabular}{|c|c|c|c|c|c|}
\hline \multirow{3}{*}{ Nome do periódico } & \multicolumn{4}{|c|}{ Uso de dados estatísticos } & \multirow{3}{*}{ Total } \\
\hline & \multicolumn{2}{|c|}{ Sim } & \multicolumn{2}{|c|}{ Náo } & \\
\hline & $\mathbf{N}$ & $\%$ & $\mathbf{N}$ & $\%$ & \\
\hline Tempo Social & 10 & $24 \%$ & 31 & $76 \%$ & 41 \\
\hline Cadernos Metrópole & 1 & $25 \%$ & 3 & $75 \%$ & 4 \\
\hline Organizaçōes \& Sociedade & 1 & $25 \%$ & 3 & $75 \%$ & 4 \\
\hline Psicologia \& Sociedade & 7 & $25 \%$ & 21 & $75 \%$ & 28 \\
\hline Saúde e Sociedade & 9 & $32 \%$ & 19 & $68 \%$ & 28 \\
\hline Dilemas & 15 & $33 \%$ & 31 & $67 \%$ & 46 \\
\hline Novos Estudos Cebrap & 1 & $33 \%$ & 2 & $67 \%$ & 3 \\
\hline Contemporânea & 2 & $33 \%$ & 4 & $67 \%$ & 6 \\
\hline Sociedade e Estado & 11 & $33 \%$ & 22 & $67 \%$ & 33 \\
\hline Revista Brasileira de Ciências Sociais & 9 & $38 \%$ & 15 & $63 \%$ & 24 \\
\hline Dados: Revista de Ciências Sociais & 4 & $40 \%$ & 6 & $60 \%$ & 10 \\
\hline Ciência \& Saúde Coletiva & 11 & $41 \%$ & 16 & $59 \%$ & 27 \\
\hline Trabalho, Educação e Saúde & 1 & $50 \%$ & 1 & $50 \%$ & 2 \\
\hline Estudos Feministas & 4 & $50 \%$ & 4 & $50 \%$ & 8 \\
\hline Educação e Realidade & 3 & $75 \%$ & 1 & $25 \%$ & 4 \\
\hline Opiniâo Pública & 6 & $75 \%$ & 2 & $25 \%$ & 8 \\
\hline Revista Brasileira de Estudos de População & 4 & $80 \%$ & 1 & $20 \%$ & 5 \\
\hline Cadernos de Saúde Pública & 13 & $93 \%$ & 1 & $7 \%$ & 14 \\
\hline Revista de Saúde Pública & 16 & $100 \%$ & 0 & $0 \%$ & 16 \\
\hline Total & 157 & $29 \%$ & 389 & $71 \%$ & 546 \\
\hline
\end{tabular}

Qui-quadrado: 135,464 (0,000)

Fonte: Elaborado pelos autores

A adversidade que deriva do excesso de "ênfase no esforço descritivo e a busca sempre renovada das peculiaridades" (REIS, 1993, p. 15), combinada com o rechaço ao quantitativo, seria a ausência de preocupação com o entendimento do contexto em escala mais ampla, como se a adequada apreensão de quem sấ, como vivem e com quem se relacionam os sujeitos que moram em um edifício, por exemplo, fosse suficiente para a consolidação de uma ciência que se pretende nacional.
A sociologia do crime, violência e dinâmica criminal, como subárea das ciências sociais no Brasil, parece padecer desse mal, pois, considerando os estudos que contam com algum tipo de análise de dados (384 artigos), constatamos a prevalência de análises sobre vizinhanças (as favelas e as periferias das capitais brasileiras) e instituiçôes (prisões, centros de internação, polícias, entre outras), localizadas em bairros de destaque das cidades brasileiras (Tabela 8). 
Tabela 8

Distribuição dos artigos com análise de dados de acordo com o contexto de estudo

\begin{tabular}{lccc}
\hline \multicolumn{1}{c}{ Contexto de pesquisa } & Frequência & Porcentagem & Porcentagem válida \\
\hline Local - bairro, instituição & 174 & 31,9 & 45,3 \\
\hline Cidade & 68 & 12,5 & 17,7 \\
\hline Regional - algumas cidades & 18 & 3,3 & 4,7 \\
\hline Estadual & 60 & 11,0 & 15,6 \\
\hline Nacional & 58 & 10,6 & 15,1 \\
\hline Internacional - mais de um país & 6 & 1,1 & 1,6 \\
\hline Total & 384 & 70,3 & \\
\hline Sem análise de dados & 162 & 29,7 & \\
\hline Total & 546 & 100,0 & \\
\hline
\end{tabular}

Fonte: Elaborado pelos autores

Quase a metade $(45,3 \%)$ de toda a produção estruturada a partir de análise de dados diz respeito a contextos mais imediatos, sem maior preocupação com a situação da cidade, do estado, do país. Com igual participação percentual, estão os estudos com recorte estadual $(15,6 \%)$ e regional $(15,1 \%)$. Digno de nota é o fato de que 1,6\% dos trabalhos dizem respeito às comparaçôes internacionais e 4,7\% serem comparaçóes entre municípios brasileiros. Logo, estamos diante de uma produção muito centrada na compreensão das dinâmicas de sociabilidade ou padróes de funcionamento locais, mesmo que as conclusóes de alguns estudos se pretendam aplicáveis a todo o país.

Quando comparamos o recorte com a técnica de pesquisa mobilizada (Gráfico 4), verificamos que a análise de dados qualitativa está relacionada à pesquisa de realidades mais imediatas $(54,2 \%$ dos estudos qualitativos são locais), reforçando o entendimento de que a boa compreensão de um dado contexto só pode ser alcançada por meio do trabalho de campo, com descriçóes densas, permeadas pela reprodução de trechos de entrevistas, depoimentos e frases proferidas nos diálogos entre pesquisador e sujeitos pesquisados. Existe também uma predominância do recorte centrado no bairro ou numa instituição entre os estudos com abordagens mistas (48,4\%). Por outro lado, entre os estudos quantitativos, há uma maior preocupação com a generalidade, já que quase um terço $(32,3 \%)$ diz respeito ao estado. No entanto, é importante sublinhar que mesmo entre os estudos quantitativos, 21,5\% são feitos no âmbito de uma instituição (como ocorre no survey com os juízes, promotores e policiais) ou com os moradores de um bairro. Em síntese, independentemente da metodologia abordada, o local tem preferência em relação ao nacional.

$\mathrm{Na}$ tentativa de avançar um pouco na compreensão do tipo de exame realizado nos artigos que contam com dados empíricos (384 casos), identificamos 31 estudos que se valiam de algum software para análise de dados. Entre os estudos quantitativos (23 casos), o mais citado foi o Statistical Package for the Social Sciences ${ }^{18}$, popularmente conhecido como SPSS (usado em 11 artigos), que permite a 


\section{Gráfico 4}

\section{Distribuição percentual dos recortes metodológicos por contexto de pesquisa}

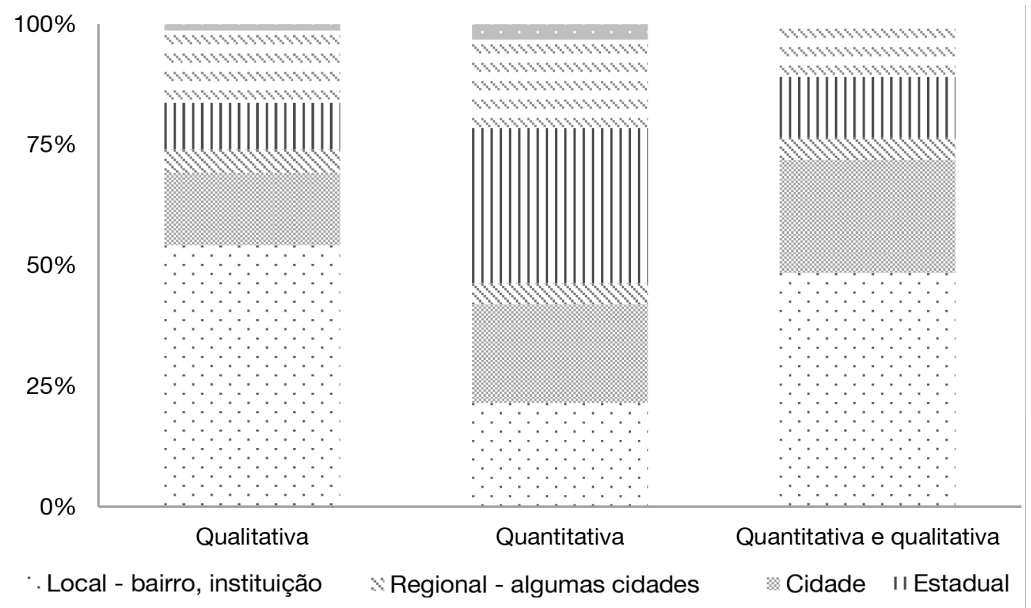

Fonte: Elaborado pelos autores

construção de tabelas de frequência e cruzamentos descritivos (como os utilizados neste estudo) e, também, modelos de regressão. Entre os estudos mistos (cinco casos), o software mais utilizado foi o Epi Info ${ }^{19}$, um programa desenvolvido para a área de saúde pública e que viabiliza desde a elaboraçáo do questionário, perpassando a alimentação das respostas, até a geração de estatísticas e mapas. No caso dos estudos qualitativos, apenas dois citaram o $\mathrm{NVivo}^{20}$, que permite a codificação de entrevistas e registros de grupos focais em texto, áudio ou vídeo e até algumas análises de relacionamento entre partes do discurso e suas condiçốes de emissão.

A baixa menção a programas (31 casos dos 546 artigos mapeados) não significa a rejeição ao uso de softwares para escrutínio de informaçóes qualitativas e quantitativas.
Talvez indique mais que a sociologia do crime, da violência e da dinâmica criminal, não menciona as ferramentas utilizadas para a geração de suas análises. Por outro lado, a baixa menção a programas de análise de dados qualitativos pode estar indicando, em certa medida, parte do argumento de Soares (2005) do não método: se é possível analisar as entrevistas como bem se entende, apenas para validar uma parte da perspectiva teórica, então, não é necessário valer-se de softwares que ajudem a fazer isso, mostrando o que pode e o que não pode ser relacionado. Se Cano (2012) estiver correto, a preferência pelo entendimento do "peculiar" (REIS, 1991) por meio de entrevistas em profundidade, analisadas manualmente sem a ajuda de softwares, resulta da forma como as ciências sociais são ensinadas e, posteriormente, construídas por

19 Disponível em: <https://bit.ly/2sfx5Mh>. Acesso em: 4 dez. 2017.

20 Disponível em: <https://bit.ly/2IQjL80>. Acesso em: 4 dez. 2017. 
profissionais de determinadas universidades. Isso significaria que os estudos quantitativos, especialmente os que fazem menção a um programa de análise de dados, estariam concentrados em determinadas universidades, liderados por certos pesquisadores.

Neuma Aguiar (2001, p. 3) concorda com esse argumento ao afirmar que as "pesquisas com base quantitativa vêm sendo empregadas por um restrito grupo de pesquisadores em ciências sociais, que encontram dificuldades em formar as novas geraçôes de profissionais nessa área”. Para ela, tão somente a regiáo Sudeste, por contar com cursos contínuos na pós-graduação voltados para a formação de pesquisadores mais quantitativos, apresentaria uma produçáo estabelecida a partir da análise de dados estruturados.

No propósito de testar esse argumento, consideramos a regiáo onde o primeiro autor das 546 publicaçôes exerce suas atividades.
Como a maior parte da produção contabilizada neste artigo foi produzida por doutores, a instituição indica o local onde o sujeito exerce suas atividades profissionais. É oportuno sublinhar que a instituição de origem do pesquisador não é, necessariamente, aquela na qual ele realizou sua formação enquanto aluno de graduação e pós-graduação, mas é um indício das possibilidades de formaçáo e atualização metodológicas às quais o profissional está exposto.

A Tabela 9 indica que o argumento de Aguiar (2001) parece não encontrar ressonância na área da sociologia do crime, violência e dinâmica criminal. Apesar de a regiáo Sudeste concentrar $57,9 \%$ dos artigos catalogados neste inventário, somente $18 \%$ das publicaçôes dessa localidade são de cunho quantitativo. Além disso, $61 \%$ dos estudos qualitativos são feitos no Sudeste. Proporcionalmente, a região Nordeste possui mais textos quantitativos, com $18 \%$ de sua produção classificada nesta dimensão.

\section{Tabela 9}

\section{Distribuição dos artigos por tipo de autoria e região onde o autor principal exerce suas atividades}

\begin{tabular}{|c|c|c|c|c|c|c|}
\hline \multirow{2}{*}{\multicolumn{2}{|c|}{ Regiáo do autor principal }} & \multicolumn{4}{|c|}{ Abordagem metodológica } & \multirow{2}{*}{ Total } \\
\hline & & Teórica & Qualitativa & Quantitativa & Mista & \\
\hline \multirow{2}{*}{ Norte } & $\mathrm{N}$ & 1 & 1 & 0 & 0 & 2 \\
\hline & $\%$ & $50,0 \%$ & $50,0 \%$ & $0,0 \%$ & $0,0 \%$ & $100,0 \%$ \\
\hline \multirow{2}{*}{ Nordeste } & $\mathrm{N}$ & 15 & 29 & 15 & 10 & 69 \\
\hline & $\%$ & $21,7 \%$ & $42,0 \%$ & $21,7 \%$ & $14,5 \%$ & $100,0 \%$ \\
\hline \multirow{2}{*}{ Centro-Oeste } & $\mathrm{N}$ & 16 & 23 & 8 & 4 & 51 \\
\hline & $\%$ & $31,4 \%$ & $45,1 \%$ & $15,7 \%$ & $7,8 \%$ & $100,0 \%$ \\
\hline \multirow{2}{*}{ Sudeste } & $\mathrm{N}$ & 84 & 138 & 57 & 37 & 316 \\
\hline & $\%$ & $26,6 \%$ & $43,7 \%$ & $18,0 \%$ & $11,7 \%$ & $100,0 \%$ \\
\hline \multirow{2}{*}{ Sul } & $\mathrm{N}$ & 32 & 30 & 13 & 12 & 87 \\
\hline & $\%$ & $36,8 \%$ & $34,5 \%$ & $14,9 \%$ & $13,8 \%$ & $100,0 \%$ \\
\hline \multirow{2}{*}{ Internacional } & $\mathrm{N}$ & 14 & 6 & 0 & 1 & 21 \\
\hline & $\%$ & $66,7 \%$ & $28,6 \%$ & $0,0 \%$ & $4,8 \%$ & $100,0 \%$ \\
\hline \multirow{2}{*}{$\begin{array}{l}\text { Total } \\
\%\end{array}$} & $\mathrm{~N}$ & 162 & 227 & 93 & 64 & 546 \\
\hline & $29,7 \%$ & $41,6 \%$ & $17,0 \%$ & $11,7 \%$ & $100,0 \%$ & \\
\hline
\end{tabular}

Qui-quadrado: 24,215 (0,062)

Fonte: Elaborado pelos autores 
Para Soares (2005) e Cano (2012) uma forma de contornar as deficiências na formaçáo quantitativa, decorrentes do pouco conhecimento de estatística por parte dos alunos da pós-graduação e, posteriormente, pesquisadores na área de ciências sociais, seria a coautoria, em que sujeitos com backgrounds diferenciados complementariam suas habilidades. Apesar de o padrão da área ser a publicação individual (que responde por $60 \%$ dos artigos inventariados), quando desagregamos a coautoria por abordagem metodológica, constatamos a prevalência de análises quantitativas naqueles estudos que contam com mais de um autor (Tabela 10). Essa hipótese parece se sustentar, já que a maior diferença dos estudos em coautoria, em relaçáo ao de autores com um único artigo, é entre os artigos que lançam mão de técnicas de pesquisa quantitativas $(27,1 \%$ versus $10,4 \%)$ e entre os que contam com uma abordagem mista (17,9\% versus 7,6\%) Entre os artigos de abordagens qualitativas e teóricas, os maiores percentuais estão na linha que identifica estudos individuais.

Tabela 10

Distribuição dos artigos com análise de dados por tipo de autoria e técnica de pesquisa mobilizada

\begin{tabular}{lcccccc}
\hline \multirow{2}{*}{ Tipo de autoria } & \multicolumn{5}{c}{ Abordagem metodológica } & \multirow{2}{*}{ Total } \\
\cline { 2 - 6 } & & Teórica & Qualitativa & Quantitativa & Mista & \\
\hline \multirow{2}{*}{ Coautoria } & $\mathrm{N}$ & 42 & 78 & 59 & 39 & 218 \\
\cline { 2 - 6 } & $\%$ & $19,3 \%$ & $35,8 \%$ & $27,1 \%$ & $17,9 \%$ & $100,0 \%$ \\
\hline \multirow{2}{*}{ Individual } & $\mathrm{N}$ & 120 & 149 & 34 & 25 & 328 \\
\hline \multirow{2}{*}{$\begin{array}{l}\text { Total } \\
\%\end{array}$} & $\mathrm{~N}$ & $36,6 \%$ & $45,4 \%$ & $10,4 \%$ & $7,6 \%$ & $100,0 \%$ \\
\hline & $29,7 \%$ & $41,6 \%$ & $17,0 \%$ & $11,7 \%$ & $100,0 \%$ & \\
\hline
\end{tabular}

Qui-quadrado: 49,389 (0,000)

Fonte: Elaborado pelos autores

Porém, ainda precisamos voltar no argumento de Aguiar (2001), de que a abordagem quantitativa estaria concentrada em alguns poucos pesquisadores, com formação densa o suficiente para mobilizaçáo desta técnica. Dos 407 primeiros autores responsáveis pela escrita dos 546 textos mapeados, 74,5\% apareceram apenas uma vez na listagem e a maior quantidade de mençóes que um mesmo autor teve foi nove (caso de Alba Zaluar). Contrastando a quantidade de vezes que o autor aparece em nossa base com o tipo de abordagem metodológica empregada
(Tabela 11), podemos detectar que pesquisadores com muitas publicaçóes tendem mais a artigos teóricos $(36,7 \%)$ do que os que contam com apenas uma publicaçáo, que tendem mais às análises qualitativas (45,7\%). Logo, entre os estudos qualitativos há certa predominância de autores com um único artigo (16,2\% de diferença quando comparado ao outro grupo). Entre os artigos com múltiplas publicaçóes, é maior a diferença com relação aos artigos teóricos $(9,4 \%)$ do que com relação aos estudos quantitativos (apenas 5,2\%). 
Tabela 11

Distribuição dos artigos com análise de dados por quantidade de vezes que o autor aparece no banco de dados e técnica de pesquisa mobilizada

\begin{tabular}{lcccccc}
\hline \multirow{2}{*}{ No de artigos por autor } & \multicolumn{5}{c}{ Abordagem metodológica } & \multirow{2}{*}{ Total } \\
\cline { 2 - 6 } & & Teórica & Qualitativa & Quantitativa & Mista & \\
\hline \multirow{2}{*}{ Apenas um } & $\mathrm{N}$ & 111 & 186 & 64 & 46 & 407 \\
\cline { 2 - 6 } & $\%$ & $27,3 \%$ & $45,7 \%$ & $15,7 \%$ & $11,3 \%$ & $100,0 \%$ \\
\hline \multirow{2}{*}{ Múltiplos } & $\mathrm{N}$ & 51 & 41 & 29 & 18 & 139 \\
\cline { 2 - 6 } & $\%$ & $36,7 \%$ & $29,5 \%$ & $20,9 \%$ & $12,9 \%$ & $100,0 \%$ \\
\hline \multirow{2}{*}{ Total \% } & $\mathrm{N}$ & 162 & 227 & 93 & 64 & 546 \\
\hline & $\%$ & $29,7 \%$ & $41,6 \%$ & $17,0 \%$ & $11,7 \%$ & $100,0 \%$ \\
\hline
\end{tabular}

Qui-quadrado: 11,489 (0,009)

Fonte: Elaborado pelos autores

Por fim, falta ainda testar o argumento de que o uso do quantitativo está restrito a algumas instituiçóes, especialmente aquelas que contam com programas de treinamento metodológico intensivo (UFMG e USP), ou aquelas que possuem cursos regulares de metodologia quantitativa na pós-graduação (UERJ). É de se esperar que universidades com tradiçóes mais quantitativas tenham uma produção mais ancorada na análise de dados estatísticos. Novamente, vamos recorrer à instituição a que pertence o primeiro autor do texto. Os trabalhos mapeados são oriundos de 120 instituiçóes, sendo que 24 delas concentram 73,4\% do total. O maior destaque é a USP com 10,1\% das publicaçóes catalogadas, guardando uma distância de quase quatro pontos das segundas colocadas, a UFMG e a UERJ, cada qual com $6,6 \%$ dos artigos relacionados à sociologia do crime, violência e dinâmica criminal (Tabela 12).

Digno de nota é o papel ocupado pela USP que, apesar dos 12 artigos quantitativos dela originários, relativamente não foi bem classificada, já que esses representam somente $22 \%$ dos estudos publicados por pesquisadores filiados a essa universidade. Neiva (2015) explica esse resultado destacando que o curso de treinamento intensivo na USP é muito recente e ainda náo foi capaz de reverter a "notória debilidade" dos pesquisadores da casa na seara quantitativa. Aparentemente, mudar a tradição da forma como os estudos são construídos em uma dada organização é mais difícil do que parece, pois não se trata de treinar os pesquisadores em métodos, mas de convencê-los de que certas técnicas podem resultar em um conhecimento mais profundo sobre dados problemas.

\section{Tabela 12}

Distribuição dos artigos quanto à instituição de origem do primeiro autor (independentemente da técnica de pesquisa utilizada)

\begin{tabular}{lcc}
\hline $\begin{array}{c}\text { Instituiçáo a } \\
\text { que pertence o } \\
\text { primeiro autor }\end{array}$ & Frequência & Porcentagem \\
\hline FGV & 5 & 0,9 \\
\hline PUC-MG & 5 & 0,9 \\
\hline UFPB & 5 & 0,9 \\
\hline Unifesp & 5 & 0,9 \\
\hline PUC-SP & 6 & 1,1 \\
\hline & & (Continua)
\end{tabular}


Tabela 12 - continuação

\begin{tabular}{lcc}
\hline $\begin{array}{c}\text { Instituiçáo a } \\
\text { que pertence o } \\
\text { primeiro autor }\end{array}$ & Frequência & Porcentagem \\
\hline UFC & 6 & 1,1 \\
\hline Unesp & 8 & 1,5 \\
\hline Ufes & 10 & 1,8 \\
\hline $\begin{array}{l}\text { Fundação Oswaldo } \\
\text { Cruz }\end{array}$ & 14 & 2,6 \\
\hline Unicamp & 14 & 2,6 \\
\hline UFPE & 15 & 2,7 \\
\hline UFSC & 15 & 2,7 \\
\hline UFSCar & 18 & 3,3 \\
\hline UFBA & 19 & 3,5 \\
\hline PUC-RS & 20 & 3,7 \\
\hline UFF & 20 & 3,7 \\
\hline UFRGS & 29 & 5,3 \\
\hline UNB & 31 & 5,7 \\
\hline UFRJ & 33 & 6,0 \\
\hline UERJ & 36 & 6,6 \\
\hline UFMG & 36 & 6,6 \\
\hline USP & 55 & 10,1 \\
\hline Total & 401 & 73,4 \\
\hline $\begin{array}{l}\text { Outras instituiçóes } \\
\text { (com quatro ou } \\
\text { menos artigos) }\end{array}$ & 145 & 26,6 \\
\hline Total & 546 & 100 \\
\hline
\end{tabular}

Fonte: Elaborado pelos autores

Desagregando as instituiçóes de origem dos autores segundo a presença ou ausência de análise estatística na produção mapeada, é possível constatar que 68 delas não contam com qualquer produção deste tipo (Tabela 13). Outras 32 instituiçóes possuem tão somente um artigo quantitativo publicado; e outras sete possuem entre 2 e 3 artigos dessa natureza entre suas respectivas produçôes. São 12 as instituições que concentram as análises quantitativas sobre crime, violência e dinâmica criminal. A UFMG ocupa o primeiro lugar, em termos absolutos, com a maior quantidade de artigos (23 casos) que usam, pelo menos, uma tabela de frequência. Em parte, esse resultado pode ser devido ao protagonismo assumido pelo Centro de Estudos em Criminalidade e Segurança Pública (Crisp) ${ }^{21}$, que sob a liderança de Cláudio Beato Filho, desde 1996, desenvolve uma série de análises quantitativas sobre a dinâmica da criminalidade, tendo importante papel na formação de recursos humanos com este perfil.

Porém, em termos percentuais, o primeiro lugar pertence à PUC-MG, outra instituição situada em Belo Horizonte e que poderia se aproveitar do treinamento intensivo em metodologia quantitativa oferecido pela UFMG. Em seguida, temos a UFPE, com grande quantidade absoluta e relativa de artigos quantitativos (10 casos, representando 63\% da produção desta universidade), instituição que tem se destacado pela consolidação do Núcleo de Estudos e Pesquisas em Criminalidade, Violência e Políticas de Segurança Pública (Neps) ${ }^{22}$, que, sob a liderança de José Luiz Ratton, também desenvolve uma série de estudos sobre a dinâmica de criminalidade a partir do escrutínio dos dados oficiais.

Logo, a instituição a que o autor se vincula parece ter efeito sobre a produção de cunho mais quantitativo, o que parece indicar que certas universidades ainda têm sua produção sobre crime, violência e dinâmica criminal muito centrada na análise qualitativa. Contribuem para essa situação, como anteriormente destacado, a ausência de cursos regulares de metodologia quantitativa (CANO, 2012), a resistência ao uso de tabelas, como se elas solapassem dinâmicas sociais (SOARES, 2005) e a dificuldade - financeira e logística - que coleta de informaçóes mais estruturada demanda (NEIVA, 2015).

21 Cadastro no CNPq disponívele em: <https://bit.ly/2EjoNkc>. Acesso em: 8 dez. 2017.

22 Cadastro no CNPq disponível em: <https://bit.ly/2JFWNl8>. Acesso em: 8 dez. 2017. 
Tabela 13

Distribuição dos artigos quanto à instituição de origem do primeiro autor e ao uso de análise estatística (isolada ou combinada com dados qualitativos)

\begin{tabular}{|c|c|c|c|c|c|}
\hline \multirow{3}{*}{ Nome da universidade } & \multicolumn{4}{|c|}{ Uso de dados estatísticos nos artigos } & \multirow{3}{*}{ Total } \\
\hline & \multicolumn{2}{|c|}{ Sim } & \multicolumn{2}{|c|}{ Não } & \\
\hline & $\mathbf{N}$ & $\%$ & $\mathbf{N}$ & $\%$ & \\
\hline Sem trabalhos quantitativos (68 instituições) & 0 & $0 \%$ & 96 & $100 \%$ & 96 \\
\hline Com apenas um trabalho quantitativo (32 instituiçóes) & 33 & $47 \%$ & 40 & $57 \%$ & 70 \\
\hline Com dois ou três trabalhos quantitativos (7 instituiçôes) & 19 & $27 \%$ & 46 & $71 \%$ & 65 \\
\hline UNB & 7 & $21 \%$ & 26 & $79 \%$ & 33 \\
\hline UERJ & 8 & $21 \%$ & 31 & $79 \%$ & 39 \\
\hline UFSCar & 4 & $22 \%$ & 14 & $78 \%$ & 18 \\
\hline USP & 12 & $22 \%$ & 43 & $78 \%$ & 55 \\
\hline UFRJ & 9 & $27 \%$ & 24 & $73 \%$ & 33 \\
\hline UFRGS & 8 & $28 \%$ & 21 & $72 \%$ & 29 \\
\hline UFSC & 5 & $33 \%$ & 10 & $67 \%$ & 15 \\
\hline UFBA & 7 & $37 \%$ & 12 & $63 \%$ & 19 \\
\hline Fundação Oswaldo Cruz & 8 & $57 \%$ & 6 & $43 \%$ & 14 \\
\hline UFPE & 10 & $63 \%$ & 6 & $38 \%$ & 16 \\
\hline UFMG & 23 & $64 \%$ & 13 & $36 \%$ & 36 \\
\hline PUC-MG & 4 & $80 \%$ & 1 & $20 \%$ & 5 \\
\hline Total de artigos & 157 & $29 \%$ & 389 & $71 \%$ & 546 \\
\hline
\end{tabular}

Qui-quadrado: 164,863 (0,003)

Fonte: Elaborado pelos autores

Interessante destacar que, nesse momento, ao contrário do observado nos anos em que a sociologia do crime, violência e dinâmica criminal se constituía enquanto campo de estudos, a ausência de estudos mais quantitativos indica como essa área parece padecer do mesmo calcanhar de aquiles das ciências sociais. Se no início dos anos 1990 éramos uma área mais diversa, em termos de abordagens metodológicas, nos tornamos mais apegados aos estudos qualitativos realizados em pequenas localidades e, muitas vezes, sem diálogo com outros pesquisadores, que poderiam contribuir para a sofisticação metodológica.
Precisamos, assim, reverter o curso da história novamente ao nosso favor, retomando pesquisas que conjuguem diversas abordagens metodológicas e procurem explicar fenômenos mais abrangentes, ao invés de nos ocuparmos tanto com a descrição de um contexto local.

\section{Considerações finais}

A proposta deste artigo foi mapear as estratégias metodológicas que têm sido utilizadas na sociologia para o estudo do crime e da violência no Brasil. Para tanto, revisitamos os balanços da literatura da área, procurando 
captar quais eram as técnicas de pesquisa mobilizadas pelos estudos catalogados por Adorno (1993), Zaluar (1999), Kant de Lima, Misse e Miranda (2000), Barreira e Adorno (2010) e Campos e Alvarez (2017). Analisamos esses textos concomitantemente às idas e vindas do argumento do calcanhar de aquiles metodológico das ciências sociais, desenvolvido por Reis (1993), Soares (2005), Cano (2012) e Neiva (2015). Em seguida, catalogamos a produção indexada pela SciELO, tendo como base as revistas A1 e A2 na área de sociologia.

Esse inventário nos permitiu examinar 546 artigos (a maioria publicada após os anos 2000, dado que a criação do SciELO ocorreu em 1997), que versam sobre 25 temas, o que demonstra a diversidade de objetos empíricos que entrecorta a produção desse campo. Do ponto de vista metodológico, podemos constatar que a entrevista é a técnica de pesquisa mais mobilizada, sendo aplicada em estudos qualitativos ou quantitativos (quando as respostas estruturadas são transformadas em frequências), mas a etnografia tem ocupado um espaço cada vez maior.

Por outro lado, existe um uso premente de informaçóes quantitativas, a partir do escrutínio dos bancos de dados cedidos pela administração pública, como é o caso das Informações sobre Mortalidade (SIM/DATASUS), dos registros policiais, além de informações judiciais cada vez mais acessíveis. Aparentemente, o problema do quantitativo se inicia quando o pesquisador é desafiado a construir a sua própria pesquisa, aplicando questionários do tipo survey, ou ainda quando ele precisa ir além das tabelas de frequência, já que a formação metodológica nessa área parece ser, todavia, um tanto quanto deficiente. Exatamente por isso, para superar esse obstáculo, UFMG e USP têm se empenhado cada vez mais na realização de cursos que, durante as férias escolares, procuram reverter as deficiências de formação de nossos pesquisadores.
Seguindo o argumento apresentado por Neiva (2015), abordamos o tamanho proporcional da classe dos trabalhos que contam com algum tipo de análise quantitativa - isolada ou concomitante, como ocorre no caso dos desenhos mistos. No artigo por ele publicado em 2015, os estudos com algum tipo de inspeção estatística somavam $26,7 \%$, considerando todas as revistas A1, A2 e B1 das ciências sociais. A sociologia do crime, violência $\mathrm{e}$ dinâmica criminal conta com $29 \%$ produçóes com essa característica entre as revistas A1 e A2, publicaçóes essas que estão concentradas em algumas universidades e, muitas vezes, são viabilizadas por intermédio da coautoria. Logo, temos a mesma fraqueza da grande área na realização de estudos que sejam mais generalistas e trabalhem com dados estruturados.

No que se refere aos determinantes da análise quantitativa, os dados avaliados indicam que a instituição à qual pertence o primeiro autor importa mais para entendimento do uso de análises quantitativas no âmbito da sociologia do crime, violência e dinâmica criminal do que a região na qual ela se realiza. Além disso, os estudos de caráter mais numéricos tendem a contar com mais colaboraçóes do que aqueles que utilizam uma abordagem mais qualitativa, que são mais comuns na autoria individual.

Logo, o calcanhar de aquiles da sociologia do crime, violência e dinâmica criminal parece ser a realização de estudos quantitativos, com recortes mais comparativos em âmbito nacional (várias cidades e regióes), o que demanda uma formação intensiva em metodologias de coleta de informaçóes (como a relativa ao survey) e análise de dados (para além das tabelas descritivas de frequências) e, por conseguinte, levaria à mobilização de softwares pouco mencionados nos trabalhos analisados neste artigo.

Nesse contexto, parece ser uma tarefa urgente, a ser encarada pelos programas de 
pós-graduação em ciências sociais, a oferta regular de cursos que náo apenas ensinem análise de dados quantitativos, mas que motivem os nossos cientistas sociais a incluir essa dimensão como abordagem de seus problemas de pesquisa. A rejeição ao uso de técnicas quantitativas por parte dos pesquisadores da área faz com que a saúde pública se aproprie cada vez mais desta forma de análise de dados, tornando suas revistas as mais apropriadas para publicaçóes estruturadas a partir dessa abordagem. Essa constatação pode estar apontando para uma perspectiva ainda não explorada pelos sociólogos do crime, da violência e da dinâmica criminal: a parceria com outros profissionais de outros campos do conhecimento, uma estratégia pouco mobilizada em razão da valorização do trabalho autoral.

Precisamos avançar rumo ao entendimento de que a compreensão da vida social se faz por intermédio do diálogo e esse pode ser explorado a partir da construção de pesquisas conjuntas com a área de saúde (que utiliza surveys há muito mais tempo do que nós) ou, pelo menos, a partir da apropriação dos cursos de metodologia ensinados nas escolas de saúde pública para a formação de seus profissionais. Sair da clausura da entrevista em profundidade, cuja escrita dos resultados se dá de maneira solitária nos gabinetes universitários, parece ser o desafio da sociologia do crime, violência e dinâmica criminal nos próximos anos.

Compete-nos, talvez, tomar o primeiro passo em direção à superação da "hostilidade extrema entre as diversas escolas" (CANO, 2012, p. 106) metodológicas existentes. Se os cursos de formação metodológica intensivos ou o diagnóstico feito neste artigo será capaz de mudar essa realidade de excessivo apego ao qualitativo, só o futuro dirá. Fica aqui o desafio de acompanharmos essas mudanças e, quem sabe, nos colocarmos como protagonistas delas.

\section{Referências}

\section{Citadas para além do mapeamento}

ADORNO, S. A criminalidade urbana violenta no Brasil: um recorte temático. Revista Brasileira de Informação Bibliográfica em Ciências Sociais, Rio de Janeiro, n. 35, p. 3-24, 1993.

AGUIAR, N. Qual a contribuiçấo dos métodos quantitativos em ciências sociais para o conhecimento da sociedade brasileira? In: ENCONTRO ANUAL DA ANPOCS, 25., 2001, Caxambu. Anais... Caxambu: Hotel Glória, 2001. p. 1-15.

BARREIRA, C.; ADORNO, S. A violência na sociedade brasileira. In: MARTINS, C. B.; MARTINS, H. H. T. S. (Orgs.). Horizontes das ciências sociais no Brasil: sociologia. São Paulo: Anpocs, 2010. p. 303-374.

CAMPOS, M. S.; ALVAREZ, M. C. Políticas públicas de segurança, violência e punição no Brasil (2000-2016). In: MICELI, S.; MARTINS, C. B. (Orgs.). Sociologia brasileira hoje. Cotia: Ateliê, 2017. p. 143-217.

CANO, I. Nas trincheiras do método: o ensino da metodologia das ciências sociais no Brasil. Sociologias, Porto Alegre, v. 14, n. 31, p. 94-119, 2012.

CANO, I.; ROJIDO, E. Mapeo de programas de prevención de homicidios en América Latina y el Caribe: informe final. Rio de Janeiro: Laboratório de Análise da Violência da Universidade do Estado do Rio de Janeiro, 2016. 
DAS, V.; POOLE, D. Anthropology in the margins of the State. Political and Legal Anthropology Review, Hoboken, v. 30, n. 1, p. 140-144, 2004.

FREITAS, R.; RIBEIRO, L. Some current developments in Brazilian sociology of crime: towards a criminology? International Journal of Criminology and Sociology, Ontario, v. 3, p. 175-185, 2014.

LIMA, R.; AZEVEDO, R.; RATTON, J. L. As ciências sociais e os pioneiros nos estudos sobre crime, violência e direitos humanos no Brasil. São Paulo: Anpocs, 2011.

KANT DE LIMA, R.; MISSE, M.; MIRANDA, A. P. M. Violência, criminalidade, segurança pública e justiça criminal no Brasil: uma bibliografia. Revista Brasileira de Informação Bibliográfica em Ciências Sociais, São Paulo, n. 50, p. 45-123, 2000.

NEIVA, P. Revisitando o calcanhar de aquiles metodológico das ciências sociais no Brasil. Sociologia, Problemas e Práticas, Lisboa, n. 79, p. 65-83, 2015.

PEIRANO, M. Etnografia não é método. Horizontes Antropológicos, Porto Alegre, v. 20, n. 42, p. 377-391, 2014.

REIS, F. W. O tabeláo e a lupa: teoria, método generalizante e ideografia no contexto brasileiro. Revista Brasileira de Ciências Sociais, São Paulo, v. 16, n. 6, p. 27-42, 1991.

. Ciência e tecnologia no Brasil: uma nova política para um mundo global. Belo Horizonte: Universidade Federal de Minas Gerais, 1993. Disponível em: <https://bit.ly/2qnWeDV>. Acesso em: 10 abr. 2018.

SOARES, G. O calcanhar metodológico da ciência política no Brasil. Sociologia, Problemas e Práticas, Lisboa, n. 48, p. 27-52, 2005.

ZALUAR, A. Violência e crime. In: ASSOCIAÇÃO NACIONAL DE PÓS-GRADUAÇÃO E PESQUISA EM CIÊNCIAS SOCIAIS. O que ler na ciência social brasileira (1970-1995). São Paulo: Anpocs, 1999. v. 1, p. 13-107.

\section{Coletadas no mapeamento (e não necessariamente citadas)}

ABDALA, C. Aplicação da Lei Maria da Penha nas delegacias de mulheres: o caso do Rio de Janeiro. Dilemas, Rio de Janeiro, v. 4, n. 4, p. 571-600, 2011.

ADORNO, S. A prisāo sob a ótica de seus protagonistas: itinerário de uma pesquisa. Tempo Social, São Paulo, v. 3, n. 1-2, p. 7-40, 1991.

. Conflitualidade e violência: reflexôes sobre a anomia na contemporaneidade. Tempo Social, São Paulo, v. 10, n. 1, p. 19-47, 1998.

. Insegurança versus direitos humanos: entre a lei e a ordem. Tempo Social, São Paulo, v. 11, n. 2, p. 129-153, 1999. 
. Exclusão socioeconômica e violência urbana. Sociologias, Porto Alegre, n. 8, p. 84-135, 2002.

. Lei e ordem no segundo governo FHC. Tempo Social, São Paulo, v. 15, n. 2, p. 103-140, 2003.

Violência e impunidade penal: da criminalidade detectada à criminalidade investigada. Dilemas, Rio de Janeiro, v. 3, n. 7, p. 51-84, 2010.

ADORNO, S.; PASINATO, W. A justiça no tempo, o tempo da justiça. Tempo Social, São Paulo, v. 19, n. 2, p. 131-155, 2007.

AIDAR, T. O impacto das causas violentas no perfil de mortalidade da população residente no município de Campinas: 1980 a 2000. Revista Brasileira de Estudos de População, Belo Horizonte, v. 20, n. 2, p. 281-302, 2003.

ALBERNAZ, E. R. Na fronteira entre o bem e o mal: ética profissional e moral religiosa entre policiais militares evangélicos cariocas. Caderno CRH, Salvador, v. 23, n. 60, p. 525-539, 2010.

ALENCAR, R. A. C. Justiça criminal e punição para traficantes e usuários de drogas no Distrito Federal: análise dos processos criminais no período de 2002 a 2010. Sociedade e Estado, Brasília, DF, v. 32, n. 1, p. 273, 2017.

ALMEIDA, D. M. et al. Satisfação no trabalho dos policiais militares do Rio Grande do Sul: um estudo quantitativo. Psicologia: Ciência e Profissão, Brasília, DF, v. 36, n. 4, p. 801-815, 2016.

ALMEIDA, F. M. “Os anormais”: Foucault, Michel. Sociologias, Porto Alegre, n. 16, p. 360-367, 2006.

Descontinuidades e ressurgências: entre o normal e o patológico na teoria do controle social. História, Ciência e Saúde, Rio de Janeiro, v. 20, n. 3, p. 1057-1078, 2013.

ALMEIDA, K. Orfandade por violência doméstica contra a mulher: uma pesquisa biográfica. Civitas, Porto Alegre, v. 16, n. 1, p. e20-e35, 2016.

ALMEIDA, O. L.; PAES-MACHADO, E. Processos sociais de vitimização prisional. Tempo Social, São Paulo, v. 25, n. 1, p. 257-286, 2013.

ALMEIDA, T. M. C. As raízes da violência na sociedade patriarcal. Sociedade e Estado, Brasília, DF, v. 19, n. 1, p. 235-243, 2004.

Corpo feminino e violência de gênero: fenômeno persistente e atualizado em escala mundial. Sociedade e Estado, Brasília, DF, v. 29, n. 2, p. 329-340, 2014.

ALMEIDA, V. P. Repercussôes da violência na construção da identidade feminina da mulher presa: um estudo de caso. Psicologia: Ciência e Profissão, Brasília, DF, v. 26, n. 4, p. 604-619, 2006.

ALMEIDA, V. R. Consenso à brasileira: exame da justiça consensual criminal sob perspectiva antropológica. Dilemas, Rio de Janeiro, v. 7, n. 3, p. 731-765, 2014. 
ALVAREZ, A. M. S.; ALVARENGA, A. T.; FIEDLER-FERRARA, N. O encontro transformador em moradores de rua na cidade de São Paulo. Psicologia \& Sociedade, Belo Horizonte, v. 16, n. 3, p. 47-56, 2004.

ALVAREZ, M. C. A criminologia no Brasil ou como tratar desigualmente os desiguais. Dados, Rio de Janeiro, v. 45, n. 4, p. 677-704, 2002.

ALVAREZ, M. C.; FRAGA, P. C. P.; CAMPOS, M. S. Apresentação: perspectivas atuais sobre políticas, produção, comércio e uso de drogas. Tempo Social, São Paulo, v. 29, n. 2, p. 1-14, 2017.

ALVAREZ, M. C.; SALLA, F.; DIAS, C. N. Das comissôes de solidariedade ao Primeiro Comando da Capital em São Paulo. Tempo Social, São Paulo, v. 25, n. 1, p. 61-82, 2013.

AMARAL, L. B. M. et al. Violência doméstica e a Lei Maria da Penha: perfil das agressóes sofridas por mulheres abrigadas em unidade social de proteção. Estudos Feministas, Florianópolis, v. 24, n. 2, p. 521-540, 2016.

AMARO, M. C. P.; ANDRADE, S. M.; GARANHANI, M. L. A atuação do serviço de saúde na violência sob o olhar de lideranças comunitárias de Londrina (PR). Saúde e Sociedade, São Paulo, v. 17, n. 3, p. 171-180, 2008.

ANCHIETA, V. C. C.; GALINKIN, A. L. Policiais civis: representando a violência. Psicologia \& Sociedade, Belo Horizonte, v. 17, n. 1, p. 29-37, 2005.

ANDRADE, E. M. et al. A visão dos profissionais de saúde em relação à violência doméstica contra crianças e adolescentes: um estudo qualitativo. Saúde e Sociedade, São Paulo, v. 20, n. 1, p. 147-155, 2011.

ANDRADE, K. R. Violência conjugal: uma análise exploratória das potencialidades dos surveys de vitimização. Dilemas, Rio de Janeiro, v. 1, n. 2, p. 81-94, 2008.

ANDRADE, L. T.; DINIZ, A. M. A. A reorganização espacial dos homicídios no Brasil e a tese da interiorizaçáo. Revista Brasileira de Estudos de População, Rio de Janeiro, v. 30, p. S171-S191, 2013. Suplemento.

ANDRADE, S. M. O. et al. Vítimas da violência em Campo Grande: um retrato de seis anos revelado pelos dados oficiais. Saúde e Sociedade, São Paulo, v. 17, n. 3, p. 201-210, 2008.

AQUINO, J. P. D. Subvertendo o Código Penal e a monogamia: arranjos afetivos e familiares envolvendo praticantes de assaltos contra instituições financeiras. Dilemas, Rio de Janeiro, v. 10, n. 1, p. 84-111, 2017.

ARAÚJO, F. A. "Não tem corpo, não tem crime": notas socioantropológicas sobre o ato de fazer desaparecer corpos. Horizontes Antropológicos, Porto Alegre, v. 22, n. 46, p. 37-64, 2016.

ARAÚJO, M. P. et al. Violência urbana em Novo Hamburgo: notas introdutórias. Ciências Sociais Unisinos, São Leopoldo, v. 44, n. 3, p. 199-207, 2008.

ARGUELHES, D. W.; PARGENDLER, M. Custos colaterais da violência no Brasil: rumo a um direito moldado pela insegurança? Revista Direito GV, São Paulo, v. 9, n. 1, p. 269-297, 2013. 
ARREGUY, M. E. A leitura das emoções e o comportamento violento mapeado no cérebro. Physis, Rio de Janeiro, v. 20, n. 4, p. 1267-1292, 2010.

ARRUDA, A. et al. De pivete a funqueiro: genealogia de uma alteridade. Cadernos de Pesquisa, Sáo Paulo, v. 40, n. 140, p. $407-425,2010$.

AUGUSTO, C. B.; ORTEGA, F. Nina Rodrigues e a patologização do crime no Brasil. Revista Direito GV, São Paulo, v. 7, n. 1, p. 221-236, 2011.

AZAMBUJA, M. P. R.; NOGUEIRA, C. Introduçáo à violência contra as mulheres como um problema de direitos humanos e de saúde pública. Saúde e Sociedade, São Paulo, v. 17, n. 3, p. 101-112, 2008.

AZEVEDO, E. F. A polícia e suas polícias: clientela, hierarquia, soldado e bandido. Psicologia: Ciência e Profissão, Brasília, DF, v. 37, n. 3, p. 553-564, 2017.

AZEVEDO, M. A. Concepções sobre criminalidade e modelos de policiamento. Psicologia: Ciência e Profissão, Brasília, DF, v. 23, n. 3, p. 18-25, 2003.

AZEVEDO, R. G. Juizados especiais criminais: uma abordagem sociológica sobre a informalização da justiça penal no Brasil. Revista Brasileira de Ciência Sociais, São Paulo, v. 16, n. 47, p. 97-110, 2001.

Criminalidade e justiça penal na América Latina. Sociologias, Porto Alegre, n. 13, p. 212-241, 2005.

Sistema penal e violência de gênero: análise sociojurídica da Lei 11.340/06. Sociedade e Estado, Brasília, DF, v. 23, n. 1, p. 113-135, 2008.

AZEVEDO, R. G.; CIFALLI, A. C. Política criminal e encarceramento no Brasil nos governos Lula e Dilma. Civitas, Porto Alegre, v. 15, n. 1, p. 105-127, 2015.

AZEVEDO, R. G.; VASCONCELLOS, F. B. O inquérito policial em questão: situação atual e a percepção dos delegados de polícia sobre as fragilidades do modelo brasileiro de investigaçáo criminal. Sociedade e Estado, Brasília, DF, v. 26, n. 1, p. 59-75, 2011.

BALleSTRIN, L. M. A. Sociedade civil, democracia e violência. Revista Brasileira de Ciências Sociais, São Paulo, v. 30, n. 87, p. 143-162, 2015.

BANDEIRA, L. M. Três décadas de resistência feminista contra o sexismo e a violência feminina no Brasil: 1976 a 2006. Sociedade e Estado, Brasília, DF, v. 24, n. 2, p. 401-438, 2009.

. Violência de gênero: a construção de um campo teórico e de investigação. Sociedade e Estado, Brasília, DF, v. 29, n. 2, p. 449-469, 2014.

BARBOSA. W. F. Redefiniçôes da condição de morador: classificaçôes das clientelas no mandato policial cotidiano e suas consequências nas relaçôes entre polícia e população. Caderno CRH, Brasília, DF, v. 28, n. 75, p. 639-656, 2015. 
BARCELlOS, C.; ZALUAR, A. Homicídios e disputas territoriais nas favelas do Rio de Janeiro. Revista de Saúde Pública, São Paulo, v. 48, n. 1, p. 94-102, 2014.

BARCINSKI, M. Centralidade de gênero no processo de construçáo da identidade de mulheres envolvidas na rede do tráfico de drogas. Ciência \& Saúde Coletiva, Rio de Janeiro, v. 14, n. 5, p. 1843-1853, 2009a.

. Protagonismo e vitimização na trajetória de mulheres envolvidas na rede do tráfico de drogas no Rio de Janeiro. Ciência \& Saúde Coletiva, Rio de Janeiro, v. 14, n. 2, p. 577-586, 2009 b.

Mulheres no tráfico de drogas: retratos da vitimização e do protagonismo feminino. Civitas, Porto Alegre, v. 16, n. 1, p. 59-70, 2016.

BARREIRA, C. Pistoleiro ou vingador: construção de trajetórias. Sociologias, Porto Alegre, n. 8, p. 52-83, 2002.

Violência difusa, medo e insegurança: as marcas recentes da crueldade. Revista Brasileira de Sociologia, São Cristóvão, v. 1, n. 1, p. 217-242, 2013.

Crueldade: a face inesperada da violência difusa. Sociedade e Estado, Brasília, DF, v. 30, n. 1, p. 55-74, 2015.

BARRETO, A. F.; MEDRADO, B.; QUADROS, M. T. Dor, revolta e outros matizes: análises político-afetivas da violência urbana. Psicologia \& Sociedade, Belo Horizonte, v. 25, n. 2, p. 342-352, 2013.

BATISTA, A. S. Estado e controle nas prisōes. Caderno CRH, Salvador, v. 22, n. 56, p. 399-410, 2009.

BATITUCCI, E. C. et al. A justiça informal em linha de montagem: estudo de caso da dinâmica de atuação do JECrim de Belo Horizonte. Civitas, Porto Alegre, v. 10, n. 2, p. 245-269, 2010.

BAZON, M. R. Violências contra crianças e adolescentes: análise de quatro anos de notificaçóes feitas ao Conselho Tutelar na cidade de Ribeirão Preto, São Paulo, Brasil. Cadernos de Saúde Pública, Rio de Janeiro, v. 24, n. 2, p. 323-332, 2008.

BEATO FILHO, C. C. Determinantes da criminalidade em Minas Gerais. Revista Brasileira de Ciências Sociais, São Paulo, v. 13, n. 37, p. 74-87, 1998.

BEATO FILHO, C. C.; PEIXOTO, B. T.; ANDRADE, M. V. Crime, oportunidade e vitimização. Revista Brasileira de Ciências Sociais, São Paulo, v. 19, n. 55, p. 73-89, 2004.

BEATO FILHO, C. C.; RIBEIRO, L. Discutindo a reforma das polícias no Brasil. Civitas, Porto Alegre, v. 16, n. 4, p. e174-e204, 2016.

BEATO FILHO, C. C.; SILVA, B. F. A.; TAVARES, R. Crime e estratégias de policiamento em espaços urbanos. Dados, Rio de Janeiro, v. 51, n. 3, p. 687-717, 2008.

BEATO FILHO, C. C.; ZILLI, L. F. A estruturaçāo de atividades criminosas: um estudo de caso. Revista Brasileira de Ciências Sociais, Săo Paulo, v. 27, n. 80, p. 71-88, 2012. 
BECKER, S.; SOUZA, O. C. N.; OLIVEIRA, J. E. A prevalência da lógica integracionista: negaçóes à perícia antropológica em processos criminais do Tribunal de Justiça do Mato Grosso do Sul. Etnográfica, Lisboa, v. 17, n. 1, p. 97-120, 2013.

BELELI, I. Novos cenários: entre o "estupro coletivo" e a "farsa do estupro" na sociedade em rede. Cadernos Pagu, Campinas, n. 47, p. e164710, 2016.

BELLONI, M. L. Infância, máquinas e violência. Educação \& Sociedade, Campinas, v. 25, n. 87, p. 575-598, 2004.

BERDET, M. B. O papel das evidências na investigaçăo do crime de homicídio. Dilemas, Rio de Janeiro, v. 7, n. 4, p. 769-793, 2014.

BERTELLI, G. B. Errâncias racionais: a periferia, o rap e a política. Sociologias, Porto Alegre, v. 14, n. 31, p. 214-237, 2012.

BESSA, K. A. M. O crime de sedução e as relações de gênero. Cadernos Pagu, Campinas, n. 2, p. 175-196, 1994.

BICALHO, P. P. G.; KASTRUP, V.; REISHOFFER, J. C. Psicologia e segurança pública: invenção de outras máquinas de guerra. Psicologia \& Sociedade, Belo Horizonte, v. 24, n. 1, p. 56-65, 2012.

BICUDO, H. A justiça anda devagar. Lua Nova, São Paulo, n. 2, p. 85-89, 1984.

BILLAND, J. Desconstruindo expectativas de gênero a partir de uma posição minoritária: como dialogar com homens autores de violência contra mulheres? Ciência \& Saúde Coletiva, Rio de Janeiro, v. 22, n. 9, p. 2979-2988, 2017.

BIONDI, K.; MARQUES, A. Memória e historicidade em dois "comandos" prisionais. Lua Nova, São Paulo, n. 79, p. 39-70, 2010.

BIRMAN, P. Feitiçarias, territórios e resistências marginais. Mana, Rio de Janeiro, v. 15, n. 2, p. 321-348, 2009.

. Cruzadas pela paz: práticas religiosas e projetos seculares relacionados à questáo da violência no Rio de Janeiro. Religiäo \& Sociedade, Rio de Janeiro, v. 32, n. 1, p. 209-226, 2012.

BIRMAN, P.; FERNANDES, A.; PIEROBON, C. Um emaranhado de casos: tráfico de drogas, estado e precariedade em moradias populares. Mana, Rio de Janeiro, v. 20, n. 3, p. 431-460, 2014.

BIRMAN, P.; MACHADO, C. A violência dos justos: evangélicos, mídia e periferias da metrópole. Revista Brasileira de Ciências Sociais, Săo Paulo, v. 27, n. 80, p. 55-69, 2012.

BITTENCOURT, M. B. Poder punitivo e teoria social. Dilemas, Rio de Janeiro, v. 9, n. 2, p. 271-292, 2015.

Seletividade penal e criminalidade violenta: os esquadrōes da morte e as masmorras no estado do Espírito Santo. Dilemas, Rio de Janeiro, v. 10, n. 2, p. 189-213, 2017.

BONAMIGO, I. S. et al. Violências, direitos humanos e segurança pública em debate. Psicologia: Ciência e Profissão, Brasília, DF, v. 31, n. 4, p. 800-813, 2011. 
BRAGA, A. G. M. Entre a soberania da lei e o chão da prisão: a maternidade encarcerada. Revista Direito GV, São Paulo, v. 11, n. 2, p. 523-546, 2015.

BRAGAGNOLO, R. I.; LAGO, M. C. S.; RIFIOTIS, T. Estudo dos modos de produçấo de justiça da Lei Maria da Penha em Santa Catarina. Estudos Feministas, Florianópolis, v. 23, n. 2, p. 601-617, 2015.

BRANDÃO, S. V. Perfil do idoso acusado de cometer crime. Dilemas, Rio de Janeiro, v. 10, n. 2, p. 259-277, 2017.

BREITMA, M. R. Criminalidade feminina: outra versão dos papéis da mulher. Sociologias, Porto Alegre, n. 1, p. 200-223, 1999.

BRILHANTE, A. V. M. et al. Um estudo bibliométrico sobre a violência de gênero. Saúde e Sociedade, São Paulo, v. 25, n. 3, p. 703-715, 2016.

BRINO, R. F.; SOUZA, M. A. O. Concepções sobre violência intrafamiliar na área educacional. Educação \& Realidade, Porto Alegre, v. 41, n. 4, p. 1251-1273, 2016.

BRITES, J.; FONSECA, C. As metamorfoses de um movimento social: mães de vítimas de violência no Brasil. Análise Social, Lisboa, n. 209, p. 858-877, 2013.

BRITO, A. S.; SOUZA, L. Representações sociais de policiais civis sobre profissionalização. Sociologias, Porto Alegre, n. 12, p. 304-327, 2004.

BRUNI, J. C. Foucault: o silêncio dos sujeitos. Tempo Social, São Paulo, v. 1, n. 1, p. 199-207, 1989.

BRUNO, R. A. L. Nova República: a violência patronal rural como prática de classe. Sociologias, Porto Alegre, n. 10, p. 284-310, 2003.

BUENO, S.; LIMA, R. S.; TEIXEIRA, M. A. C. Sujeito ou demandante? reflexôes sobre o caráter da participação nos conselhos comunitários de segurança de São Paulo. Sociologias, Porto Alegre, v. 18, n. 42, p. 328-355, 2016.

CALDEIRA, C. Segurança pública e sequestros no Rio de Janeiro (1995-1996). Tempo Social, Săo Paulo, v. 9, n. 1, p. 115-153, 1997.

CAMPOS, C. H. Juizados especiais criminais e seu déficit teórico. Estudos Feministas, Florianópolis, v. 11, n. 1, p. $155-170,2003$.

CAMPOS, C. H.; CARVALHO, S. Violência doméstica e juizados especiais criminais: análise a partir do feminismo e do garantismo. Estudos Feministas, Florianópolis, v. 14, n. 2, p. 409-422, 2006.

CAMPOS, M. S. Mídia e política: a construção da agenda nas propostas de redução da maioridade penal na Câmara dos Deputados. Opiniāo Pública, Campinas, v. 15, n. 2, p. 478-509, 2009.

. Drogas e justiça criminal em São Paulo: uma análise da origem social dos criminalizados por drogas desde 2004 a 2009. Contemporânea, São Carlos, v. 5, n. 1, p. 167-189, 2015. 
CAMPOS, M. S.; ALVAREZ, M. C. Pela metade: implicações do dispositivo médico-criminal da "nova" Lei de Drogas na cidade de São Paulo. Tempo Social, São Paulo, v. 29, n. 2, p. 45-74, 2017.

CAMPOS, M. A. M. R. et al. Violência sexual: integração saúde e segurança pública no atendimento imediato à vítima. Saúde e Sociedade, São Paulo, v. 14, n. 1, p. 101-109, 2005.

CAMPOS, M. A. M. R.; SCHOR, N. Violência sexual como questão de saúde pública: importância da busca ao agressor. Saúde e Sociedade, São Paulo, v. 17, n. 3, p. 190-200, 2008.

CARDIA, N. O medo da polícia e as graves violaçôes dos direitos humanos. Tempo Social, São Paulo, v. 9, n. 1, p. 249-265, 1997.

CARDOSO, F. L. M. G. Homicídios no Rio de Janeiro, Brasil: uma análise da violência letal. Ciência \& Saúde Coletiva, Rio de Janeiro, v. 21, n. 4, p. 1277-1288, 2016.

CARDOSO, M. A linguagem dos direitos: o simbólico nas reclamações dos moradores de favelas. Ciências Sociais Unisinos, Săo Leopoldo, v. 48, n. 3, p. 205-214, 2012.

CARUSO, H. A ordem e a desordem de ontem e de hoje: notas etnográficas sobre a polícia na Lapa carioca. Civitas, Porto Alegre, v. 15, n. 1, p. 66-83, 2015.

CARVALHO, D. T.; MAYORGA, C. Contribuiçôes feministas para os estudos acerca do aprisionamento de mulheres. Estudos Feministas, Florianópolis, v. 25, n. 1, p. 99-116, 2017.

CARVALHO, L. A.; ESPÍNDULA, D. H. P. Discussōes em torno do referendo sobre o comércio de armas de fogo e munição na Folha de S. Paulo. Opinião Pública, Campinas, v. 22, n. 2, p. 446-465, 2016.

CARVALHO, M. L. et al. Perfil dos internos no sistema prisional do Rio de Janeiro: especificidades de gênero no processo de exclusão social. Ciência \& Saúde Coletiva, Rio de Janeiro, v. 11, n. 2, p. 461-471, 2006.

CARVALHO JÚNIOR, O. L. Mídia e criminalidade: acertos e impasses no agenda-setting e no accoutability. Ciências Sociais Unisinos, São Leopoldo, v. 46, n. 2, p. 187-196, 2010.

CASTRO, M. L.; CUNHA, S. S.; SOUZA, D. P. O. Comportamento de violência e fatores associados entre estudantes de Barra do Garças, MT. Revista de Saúde Pública, São Paulo, v. 45, n. 6, p. 1054-1061, 2011.

CASTRO, M. S. M. Regionalização como estratégia para a definição de políticas públicas de controle de homicídios. Cadernos de Saúde Pública, Rio de Janeiro, v. 20, n. 5, p. 1269-1280, 2004.

CASTRO, M. S. M.; ASSUNÇÃO, R. M.; DURANTE, M. O. Comparação de dados sobre homicídios entre dois sistemas de informação, Minas Gerais. Revista de Saúde Pública, São Paulo, v. 37, n. 2, p. 168-176, 2003.

CAVALCANTI, M. O ambiente construído e a politização do cotidiano nas favelas cariocas. Cadernos Metrópole, São Paulo, n. 12, p. 65-93, 2004. 
CAVEDON, N. R. A qualidade de vida no trabalho na área da segurança pública: uma perspectiva diacrônica das percepçôes olfativas e suas implicaçōes na saúde dos servidores. Organizaçōes \& Sociedade, Salvador, v. 21, n. 68, p. 875-982, 2014.

CERQUEIRA, D.; LOBÃO, W. Determinantes da criminalidade: arcabouços teóricos e resultados empíricos. Dados, Rio de Janeiro, v. 47, n. 2, p. 233-269, 2004.

CERQUEIRA. R. T. Escrito em vermelho: a construção do discurso sobre criminalidade e linchamento no jornal. Caderno CRH, Salvador, v. 19, n. 47, p. 247-258, 2006.

CEZAR, P. K.; ARPINI, D. M.; GOETZ, E. R. Registros de notificação compulsória de violência envolvendo crianças e adolescentes. Psicologia: Ciência e Profissão, Brasília, DF, v. 37, n. 2, p. 432-445, 2017.

CHACHAM, A. S. Violência de gênero, desigualdade social e sexualidade. Civitas, Porto Alegre, v. 16, n. 1, p. e1-e19, 2016.

CHESNAIS, J. C. A violência no Brasil: causas e recomendaçôes políticas para a sua prevenção. Ciência \& Saúde Coletiva, Rio de Janeiro, v. 4, n. 1, p. 53-69, 1999.

CHIES, L. A. B.; PASSOS, R. A. Auxílio-reclusão: o instituto mal(mau)dito das políticas sociais com as políticas penais. Sociedade e Estado, Brasília, DF, v. 30, n. 3, p. 705-725, 2015.

CIFALI, A. C. Política criminal e governos de esquerda na América Latina: entre semelhanças e ambiguidades. Civitas, Porto Alegre, v. 16, n. 4, p. 673-681, 2016.

COELHO, M. T. A. D. Concepçôes de normalidade e saúde mental entre infratores presos de uma unidade prisional da cidade do Salvador. Ciência \& Saúde Coletiva, Rio de Janeiro, v. 14, n. 2, p. 567-575, 2009.

COLLARES-DA-ROCHA, J. C. C.; SOUZA FILHO, E. A. Representaçáo social do pecado segundo grupos religiosos. Psicologia \& Sociedade, Belo Horizonte, v. 26, n. 1, p. 235-244, 2014.

CONSTANTINO, P.; RIBEIRO, A. P.; CORREIA, B. S. C. Percepção do risco entre policiais civis de diferentes territórios do estado do Rio de Janeiro. Ciência \& Saúde Coletiva, Rio de Janeiro, v. 18, n. 3, p. 645-655, 2013.

CONTE, M. et al. Consumismo, uso de drogas e criminalidade: riscos e responsabilidades. Psicologia: Ciência e Profissão, Brasília, DF, v. 27, n. 1, p. 94-105, 2007.

CORREA, M. Bolero de machão só se canta na prisão. Lua Nova, n. 4, p. 28-32, 1986.

CORREIA, L. C.; LIMA, I. M. S. O.; ALVES, V. S. Direitos das pessoas com transtorno mental autoras de delitos. Cadernos de Saúde Pública, Rio de Janeiro, v. 23, n. 9, p. 1995-2012, 2007.

CORTINA, M. O. C. Mulheres e tráfico de drogas: aprisionamento e criminologia feminista. Estudos Feministas, Florianópolis, v. 23, n. 3, p. 761-778, 2015. 
COSTA, A. P. M. Redução da idade de imputabilidade penal: mitos e justificativas. Educação e Realidade, Porto Alegre, v. 33, n. 2, p. 47-62, 2008.

COSTA, A. T. M. As reformas nas polícias e seus obstáculos: uma análise comparada das interaçóes entre a sociedade civil, a sociedade política e as polícias. Civitas, Porto Alegre, v. 8, n. 3, p. 409-427, 2008.

É possível uma política criminal? A discricionariedade no Sistema de Justiça Criminal do DF. Sociedade e Estado, Brasília, DF, v. 26, n. 1, p. 97-114, 2011a.

. Violências e conflitos intersubjetivos no Brasil contemporâneo. Caderno CRH, Salvador, v. 24, n. 62, p. 353-365, $2011 b$.

COSTA, A. T. M.; OLIVEIRA JÚNIOR, A. Novos padrōes de investigação policial no Brasil. Sociedade e Estado, Brasília, DF, v. 31, n. 1, p. 147-164, 2016.

COSTA, D. K. G. et al. Concepçôes e práticas dos profissionais de saúde acerca da violência intrafamiliar contra crianças e adolescentes. Trabalho, Educação e Saúde, Rio de Janeiro, v. 13, p. 79-95, 2015. Suplemento 2.

CUNHA, C. C.; BOARINI, M. L. A medicina com o voto de minerva: o louco infrator. Psicologia \& Sociedade, Belo Horizonte, v. 28, n. 3, p. 442-452, 2016.

CUNHA, C. V. A cidade para os civilizados: significados da ordem pública em contextos de violência urbana. Dilemas, Rio de Janeiro, v. 5, n. 2, p. 211-232, 2012.

Religião e criminalidade: traficantes e evangélicos entre os anos 1980 e 2000 nas favelas cariocas. Religião \& Sociedade, Rio de Janeiro, v. 34, n. 1, p. 61-93, 2014.

DADALTO, M. C. Migração e violência: o "baiano" na construção da sujeição criminal na RMGV do Espírito Santo. Dilemas, Rio de Janeiro, v. 7, n. 1, p. 143-166, 2014.

DANTAS, M. A. F. "Sob a proteçấo da polícia”: o enfrentamento da violência doméstica contra a criança. Dilemas, Rio de Janeiro, v. 6, n. 1, p. 67-101, 2013.

DAUDELin, J.; RATTON, J. L. Mercados de drogas, guerra e paz no Recife. Tempo Social, São Paulo, v. 29, n. 2, p. 115-134, 2017.

DEBERT, G. G.; GREGORI, M. F. Violência e gênero: novas propostas, velhos dilemas. Revista Brasileira de Ciências Sociais, São Paulo, v. 23, n. 66, p. 165-185, 2008.

DEBERT, G. G.; OLIVEIRA, M. B. Os modelos conciliatórios de solução de conflitos e a "violência doméstica". Cadernos Pagu, Campinas, n. 29, p. 305-337, 2007.

DEEKE, L. P. et al. A dinâmica da violência doméstica: uma análise a partir dos discursos da mulher agredida e de seu parceiro. Saúde e Sociedade, São Paulo, v. 18, n. 2, p. 248-258, 2009. 
DELLASOPPA, E.; BERCOVICH, A. M.; ARRIAGA, E. Violência, direitos civis e demografia no Brasil na década de 80: o caso da área metropolitana do Rio de Janeiro. Revista Brasileira de Ciências Sociais, São Paulo, v. 14, n. 39, p. 155-176, 1999.

DELZIOVO, C. R. et al. Características dos casos de violência sexual contra mulheres adolescentes e adultas notificados pelos serviços públicos de saúde em Santa Catarina, Brasil. Cadernos de Saúde Pública, Rio de Janeiro, v. 33, n. 6, p. e00002716, 2017.

DIAS, A. A. T. Psiquiatria e criminologia na Justiça Penal: os Tribunais do Júri e de Apelação do Distrito Federal, década de 1930. História, Ciências, Saúde, Rio de Janeiro, v. 22, n. 3, p. 1033-1041, 2015.

DIAS, C. C. N. Estado e PCC em meio às tramas do poder arbitrário nas prisóes. Tempo Social, São Paulo, v. 23, n. 2, p. 213-233, 2011.

DIAS, I. Violência contra as mulheres no trabalho: o caso do assédio sexual. Sociologia, Problemas e Práticas, Oeiras, n. 57 , p. $11-23,2008$.

DIUANA, V.; CORREA, M. C. D. V.; VENTURA, M. Mulheres nas prisóes brasileiras: tensôes entre a ordem disciplinar punitiva e as prescriçóes da maternidade. Physis, Rio de Janeiro, v. 27, n. 3, p. 727-747, 2017.

DOMINGUES, F.; DESSEN, M. A. Reorganização familiar e rede social de apoio pós-homicídio juvenil. Psicologia: Teoria e Pesquisa, Brasília, DF, v. 29, n. 2, p. 141-148, 2013.

DRUMOND JÚNIOR, M. Homicídios e desigualdades sociais na cidade de São Paulo: uma visão epidemiológica. Saúde e Sociedade, São Paulo, v. 8, n. 1, p. 63-81, 1999.

DUARTE, T. L. Amor, fidelidade e compaixão: "sucata” para os presos. Sociologia \& Antropologia, Rio de Janeiro, v. 3 , n. 6, p. 621-641, 2013.

DUPREZ, D.; STETTINGER, V. Os olhos e os ouvidos do juiz? o Samre, um serviço da Justiça das crianças e dos adolescentes no Brasil (BH). Dilemas, Rio de Janeiro, n. 1, p. 235-265, 2015. Edição especial.

DURÃO, S.; COELHO, M. C. Morais do drama urbano: violência policial, discurso midiático e produção de contos morais. Sociedade e Estado, Brasília, DF, v. 29, n. 3, p. 921-940, 2014.

EFREM FILHO, R. Corpos brutalizados: conflitos e materializaçōes nas mortes de LGBT. Cadernos Pagu, Campinas, n. 46 , p. 311-340, 2016.

EIBAUM, L.; MEDEIROS, F. Quando existe "violência policial”? direitos, moralidades e ordem pública no Rio de Janeiro. Dilemas, Rio de Janeiro, v. 8, n. 3, p. 407-428, 2015.

ELEUTÉRIO, J. M. Ônibus 174: um olhar sobre a violência urbana e a exclusão social. Ciências Sociais Unisinos, São Leopoldo, v. 47, n. 2, p. 153-164, 2011. 
ESPINHEIRA. G. Violência e pobreza: janelas quebradas e o mal-estar da civilização. Caderno CRH, Salvador, v. 18, n. 45 , p. 461-470, 2005.

FANDIÑO MARIÑO, J. M. Análise comparativa dos efeitos da base socioeconômica, dos tipos de crime e das condiçôes de prisão na reincidência criminal. Sociologias, Porto Alegre, n. 8, p. 220-244, 2002.

FARIA, T. D. Mulheres no tráfico de pessoas: vítimas e agressoras. Cadernos Pagu, Campinas, n. 31, p. 151-172, 2008.

FELTRAN, G. S. Crime e castigo na cidade: os repertórios da justiça e a questão do homicídio nas periferias de São Paulo. Caderno CRH, Salvador, v. 23, n. 58, p. 59-73, 2010a.

. Margens da política, fronteiras da violência: uma ação coletiva das periferias de São Paulo. Lua Nova, São Paulo, n. 79, p. 201-233, 2010 b.

Periferias, direito e diferença: notas de uma etnografia urbana. Revista de Antropologia, São Paulo, v. 53, n. 2, p. 565-610, 2012.

O valor dos pobres: a aposta no dinheiro como mediação para o conflito social contemporâneo. Caderno $C R H$, Salvador, v. 27, n. 72, p. 495-512, 2014.

FERRARI, M. G. Polícia, antropometria e datiloscopia: história transnacional dos sistemas de identificação, do rio da Prata ao Brasil. História, Ciências, Saúde, Rio de Janeiro, v. 23, p. 171-194, 2016. Suplemento 1.

FERRAZ, S. M. T. Eu não tenho onde morar, é por isso que eu moro na rua: os "sem-teto": moradores ou transgressores? Cadernos Metrópole, São Paulo, v. 16, n. 32, p. 609-623, 2014.

FERREIRA, E. O. CAPITÃO, C. G. Agressividade e raiva: perfil de presidiários. Psicologia: Ciência e Profissão, Brasília, DF, v. 26, n. 3, p. 462-477, 2006.

FERREIRA, V. P. et al. Prevalência e fatores associados à violência sofrida em mulheres encarceradas por tráfico de drogas no estado de Pernambuco, Brasil: um estudo transversal. Ciência \& Saúde Coletiva, Rio de Janeiro, v. 19, n. 7, p. 2255-2264, 2014.

FERREIRA, V. V. F.; LITTIG, P. M. C. B.; VESCOVI, R. G. L. Crianças e adolescentes abrigados: perspectiva de futuro após situação de rua. Psicologia \& Sociedade, Belo Horizonte, v. 26, n. 1, p. 165-174, 2014.

FLECK, E. C. D.; KORNDORFER, A. P.; CADAVIZ, A. K. Da agressão à assistência, da infração à correção: menoridade e violência urbana (Porto Alegre, 1890-1920). Sociedade e Estado, Brasília, DF, v. 20, n. 1, p. 163-194, 2005.

FONSECA, D. H.; RIBEIRO, C. G.; LEAL, N. S. B. Violência doméstica contra a mulher: realidades e representaçōes sociais. Psicologia \& Sociedade, Belo Horizonte, v. 24, n. 2, p. 307-314, 2012.

FRAGA, P. C. P.; SILVA, J. K. N. A participação feminina em mercados ilícitos de drogas no Vale do São Francisco, no Nordeste brasileiro. Tempo Social, São Paulo, v. 29, n. 2, p. 135-158, 2017. 
FRANCH, M. Nada para fazer? um estudo sobre atividades no tempo livre entre jovens de periferia no Recife. Revista Brasileira de Estudos de População, Belo Horizonte, v. 19, n. 2, p. 117-133, 2002.

FREITAS, R. S.; RIBEIRO, L. Avanços e perspectivas da sociologia no Brasil: uma abordagem comparativa. Revista Brasileira de Sociologia, Belo Horizonte, n. 1, p. 69-114, 2014.

FURUKAWA, N. O PCC e a gestão dos presídios em São Paulo. Novos Estudos Cebrap, São Paulo, n. 80, p. 21-41, 2008.

GALDEANO, A. P. O desgosto da "mistura” com prostitutas e favelados: mudanças e paradoxos no campo dos direitos humanos. Dilemas, Rio de Janeiro, v. 2, n. 4, p. 127-156, 2009.

Voz e silêncio: os sentidos da violência no Conselho Comunitário de Segurança. Contemporânea, São Carlos, v. 3, n. 2, p. 335-357, 2013.

. Salmo 127, versículo 1: ativismo religioso e ordenamentos da segurança em uma periferia de São Paulo. Religião \& Sociedade, Rio de Janeiro, v. 34, n. 1, p. 38-60, 2014.

GALLO, A. E.; WILLIAMS, L. C. A. A escola como fator de proteçăo à conduta infracional de adolescentes. Cadernos de Pesquisa, São Paulo, v. 38, n. 133, p. 41-59, 2008.

GALLO, E. A. G. et al. Vitimização por crime na infância e adolescência segundo registros oficiais: coorte de nascimentos de Pelotas, Rio Grande do Sul, Brasil. Cadernos de Saúde Pública, Rio de Janeiro, v. 32, n. 8, p. e00072915, 2016.

GALVÃO, L. K. S.; CAMINO, C. P. S. Julgamento moral sobre pena de morte e redução da maioridade penal. Psicologia \& Sociedade, Belo Horizonte, v. 23, n. 2, p. 228-236, 2011.

GARCIA FILHO, C.; SAMPAIO, J. J. C. Interfaces entre a história da violência e a constituição do território no Ceará: um esforço de síntese e periodização. Saúde e Sociedade, São Paulo, v. 23, n. 4, p. 1209-1221, 2014.

GAUER, R. M. C. Violência e medo na fundação do Estado-nação. Civitas, Porto Alegre, v. 1, n. 2, p. 79-98, 2001.

GAVIRIA MEJÍA, M. R. Cultura e segurança cidadã: em busca do controle da violência na Colômbia. Sociologias, Porto Alegre, n. 18, p. 316-335, 2007.

. Controle social expresso em representaçôes sociais de violência, insegurança e medo. Sociologias, Porto Alegre, n. 20, p. 72-107, 2008.

GAWRYSZEWSKI, V. P.; KAHN, T.; MELLO JORGE, M. H. P. Informaçōes sobre homicídios e sua integração com o setor saúde e segurança pública. Revista de Saúde Pública, São Paulo, v. 39, n. 4, p. 627-633, 2005.

GERALDO, P. H. B.; BARÇANTE, L. F. S. A (des)confiança na polícia: uma comparação entre a relação do Ministério Público e a polícia no Brasil e na França. Civitas, Porto Alegre, v. 17, n. 1, p. 159-176, 2017. 
GIACOMAZZI, M. C. G. Medo e violência no contexto urbano: o caso de José. Horizontes Antropológicos, Porto Alegre, v. 6, n. 13, p. 177-194, 2000.

GIANINI, R. J.; LITVOC, J.; ELUF NETO, J. Agressão física e classe social. Revista de Saúde Pública, São Paulo, v. 33, n. 2, p. 180-186, 1999.

GODOI, R. Experiência da pena e gestão de populaçôes nas penitenciárias de São Paulo, Brasil. Etnográfica, Lisboa, v. 21, n. 1 , p. $27-48,2017$.

GOMES, R. Violência e crime: o vértice da psicanálise. Civitas, v. 1, n. 2, p. 67-78, 2001.

GONZALEZ-ARROYO, M. Quando a violência infanto-juvenil indaga a pedagogia. Educação \& Sociedade, Campinas, v. 28 , n. 100 , p. $787-807,2007$.

GRANJEIRO, I. A. C. L.; COSTA, L. F. O estudo psicossocial forense como subsídio para a decisão judicial na situação de abuso sexual. Psicologia: Teoria e Pesquisa, Brasília, DF, v. 24, n. 2, p. 161-169, 2008.

GREGORI, M. F. Relaçôes de violência e erotismo. Cadernos Pagu, Campinas, n. 20, p. 87-120. 2003.

. Práticas eróticas e limites da sexualidade: contribuiçōes de estudos recentes. Cadernos Pagu, Campinas, n. 42, p. 47-74, 2014.

GUEDES, M. A. Intervençōes psicossociais no sistema carcerário feminino. Psicologia: Ciência e Profissão, Brasília, DF, v. 26, n. 4, p. 558-569, 2006.

GUIMARÃES, C. F. et al. Homens apenados e mulheres presas: estudo sobre mulheres de presos. Psicologia \& Sociedade, Belo Horizonte, v. 18, n. 3, p. 48-54, 2006.

GUIMARÁES, R. Poder judiciário e violência contra a mulher: aplicação da Lei Maria da Penha aos conflitos domésticos e familiares. Sociedade e Estado, Brasília, DF, v. 26, n. 2, p. 431-452, 2011.

GUINDANI, M. K. A. A violência simbólica e a prisão contemporânea. Civitas, Porto Alegre, v. 1, n. 2, p. 99-112, 2001.

GULLO, A. A. S. Violência urbana: um problema social. Tempo Social, São Paulo, v. 10, n. 1, p. 105-119, 1998.

HADDAD, C. H. B.; QUARESMA, L. B. O. Dois lados da mesma moeda: o tempo no STF. Revista Direito GV, São Paulo, v. 10, n. 2, p. 639-654, 2014.

HAMBURGER, E. Expressōes fílmicas da violência urbana contemporânea: Cidade de Deus, Notícias de uma guerra particular e Falcão, meninos do tráfico. Revista de Antropologia, São Paulo, v. 51, n. 2, p. 547-574, 2008.

HIRATA, D. V.; GRILLO, C. C. Sintonia e amizade entre patrôes e donos de morro: perspectivas comparativas entre o comércio varejista de drogas em São Paulo e no Rio de Janeiro. Tempo Social, São Paulo, v. 29, n. 2, p. 75-98, 2017. 
HUGGINS, M. K. Violência urbana e privatizaçâo do policiamento no Brasil: uma mistura invisível. Caderno CRH, Salvador, v. 23, n. 60, p. 541-558, 2010.

IBRAHIM, E.; VILHENA, J. Manicômio judiciário: é possível ao louco-criminoso resistir? Psicologia: Ciência e Profissão, Brasília, DF, v. 34, n. 4, p. 879-893, 2014.

ITANI, A. A violência no imaginário dos agentes educativos. Cadernos Cedes, Campinas, v. 19, n. 47, p. 36-50, 1998.

JESUS, M. G. M. Os julgamentos do crime de tortura: um estudo processual na cidade de São Paulo. Dilemas, Rio de Janeiro, v. 3, n. 9, p. 143-172, 2010.

JESUS, N. A. O círculo vicioso da violência sexual: do ofendido ao ofensor. Psicologia: Ciência e Profissão, Brasília, DF, v. 26, n. 4, p. 672-683, 2006.

JIMENEZ, L.; FRASSETO, F. A. Face da morte: a lei em conflito com o adolescente. Psicologia \& Sociedade, Belo Horizonte, v. 27, n. 2, p. 404-414, 2015.

JULIÂO, E. F. Reincidência criminal e penitenciária: aspectos conceituais, metodológicos, políticos e ideológicos. Revista Brasileira de Sociologia, São Cristóvão, v. 4, n. 7, p. 265-291, 2016.

KHALED JÚNIOR, S. H. O Sistema Processual Penal brasileiro acusatório, misto ou inquisitório? Civitas, Porto Alegre, v. 10, n. 2, p. 293-308, 2010.

KILSZTAJN, S.; ROSSBACH, A. Vítimas fatais da violência e mercado de drogas na Região Metropolitana de São Paulo. Revista Brasileira de Estudos de População, Belo Horizonte, v. 20, n. 2, p. 259-279, 2003.

KOERNER, A. Punição, disciplina e pensamento penal no Brasil do século XIX. Lua Nova, São Paulo, n. 68, p. 205-242, 2006.

KOURY, M. G. P. O que é medo: um adentrar no imaginário dos habitantes da cidade de João Pessoa, Paraíba. Psicologia \& Sociedade, Belo Horizonte, v. 21, n. 3, p. 402-410, 2009.

Medos urbanos e mídia: o imaginário sobre juventude e violência no Brasil atual. Sociedade e Estado, Brasília, DF, v. 26, n. 3, p. 471-486, 2011.

LACERDA, P. O sofrer, o narrar, o agir: dimensôes da mobilização social de familiares de vítimas. Horizontes Antropológicos, Porto Alegre, v. 20, n. 42. p. 49-75, 2014.

LANDINI, T. S. Violência sexual contra crianças na mídia impressa: gênero e geração. Cadernos Pagu, Campinas, n. 26, p. 225-252, 2006.

LANIADO, R. N. Políticas públicas e desempenho institucional em relação à criminalidade. Organizaçôes \& Sociedade, Salvador, v. 7, n. 17, p. 99-111, 2000. 
LAVORATTI, C. O reflexo das relaçóes de gênero no cotidiano da violência sexual intrafamiliar contra crianças e adolescentes. Dilemas, Rio de Janeiro, v. 6, n. 4, p. 645-674, 2013.

LEITE, M. P. Entre o individualismo e a solidariedade: dilemas da política e da cidadania no Rio de Janeiro. Revista Brasileira de Ciências Sociais, São Paulo, v. 15, n. 44, p. 43-90, 2017.

LEMÓES, T. Pedra, cimento, corpos e moralidades: sobre crack e enfrentamentos urbanos. Revista de Antropologia, São Paulo, v. 59, n. 2, p. 197-203, 2016.

LEMOS-NELSON, A. T. Grupos de extermínio e accountability em âmbito municipal. Caderno CRH, Salvador, v. 19, n. 47, p. 233-245, 2006.

LESSA, A. Violência e impunidade em pauta: problemas e perspectivas sob a ótica da antropologia forense no Brasil. Ciência \& Saúde Coletiva, Rio de Janeiro, v. 14, n. 5, p. 1855-1863, 2009.

LICO, F. M. C.; WESTPHAL, M. F. Juventude, violência e ação coletiva. Saúde e Sociedade, São Paulo, v. 23, n. 3, p. $764-777,2014$.

LIMA, C. A.; DESLANDES, S. F. Violência sexual contra mulheres no Brasil: conquistas e desafios do setor saúde na década de 2000. Saúde e Sociedade, São Paulo, v. 23, n. 3, p. 787-800, 2014.

LIMA, F. S. S. Fatores associados à violência contra mulheres profissionais do sexo de dez cidades brasileiras. Cadernos de Saúde Pública, Rio de Janeiro, v. 33, n. 2, p. e00157815, 2017.

LIMA, G.; FURTADO, V. Política pública dos telecentros e prevenção da violência. Sociologias, Porto Alegre, n. 20, p. 192-223, 2008.

LIMA, J. S.; DESLANDES, S. F. Olhar da gestão sobre a implantação da ficha de notificação da violência doméstica, sexual e/outras violências em uma metrópole do Brasil. Saúde e Sociedade, São Paulo, v. 24, n. 2, p. 661-673, 2015.

LIMA, M. L. C. et al. Evolução de homicídios por área geográfica em Pernambuco entre 1980 e 1998. Revista de Saúde Pública, São Paulo, v. 36, n. 4, p. 462-469, 2002.

Análise espacial dos determinantes socioeconômicos dos homicídios no estado de Pernambuco. Revista de Saúde Pública, São Paulo, v. 39, n. 2, p. 176-182, 2005.

LIMA, R. S. A produção da opacidade: estatísticas criminais e segurança pública no Brasil. Novos Estudos Cebrap, São Paulo, n. 80, p. 65-69, 2008.

LIMA, R. S.; BUENO, S.; MINGARDI, G. Estado, polícias e segurança pública no Brasil. Revista Direito GV, São Paulo, v. 12, n. 1, p. 49-85, 2016.

LIMA, R. S.; SINHORETTO, J.; BUENO, S. A gestão da vida e da segurança pública no Brasil. Sociedade e Estado, Brasília, DF, v. 30, n. 1, p. 123-144, 2015. 
LIMA, R. C. P. Diagnósticos psicossociais de crianças e adolescentes na Febem de São Paulo. Cadernos de Pesquisa, São Paulo, n. 108, p. 161-181, 1999.

. Mudança das práticas sócio-educativas na Febem-SP: as representaçôes sociais de funcionários. Psicologia \& Sociedade, Belo Horizonte, v. 18, n. 1, p. 56-62, 2006.

LIMA, R. K. Polícia e exclusão na cultura judiciária. Tempo Social, São Paulo, v. 9, n. 1, p. 169-183, 1997.

Entre as leis e as normas: éticas corporativas e práticas profissionais na segurança pública e na Justiça Criminal. Dilemas, Rio de Janeiro, v. 6, n. 4, p. 549-580, 2013.

LIMA, R. K.; MOUZINHO, G. M. P. Produção e reproduçáo da tradição inquisitorial no Brasil: entre delaçóes e confissôes premiadas. Dilemas, Rio de Janeiro, v. 9, n. 3, p. 505-529, 2016.

LINS, R.; FIGUEIREDO FILHO, D.; SILVA, L. A redução da maioridade penal diminui a violência? evidências de um estudo comparado. Opiniāo Pública, Campinas, v. 22, n. 1, p. 118-139, 2016.

LOPES, R. E. et al. Juventude pobre, violência e cidadania. Saúde e Sociedade, São Paulo, v. 17, n. 3, p. 63-76, 2008.

LOPES JUNIOR, E. As redes sociais do crime organizado: a perspectiva da nova sociologia econômica. Revista Brasileira de Ciências Sociais, São Paulo, v. 24, n. 69, p. 53-68, 2009.

LORETTI, P. Para que serve uma UOP? algumas consideraçôes sobre a política de ordem pública no Rio de Janeiro. Dilemas, Rio de Janeiro, v. 8, n. 3, p. 501-528, 2015.

LOWENKRON, L. O monstro contemporâneo: notas sobre a construçấo da pedofilia como "causa política" e "caso de polícia”. Cadernos Pagu, Campinas, n. 41, p. 303-337, 2013.

MACE, E. As formas da violência urbana: uma comparação entre França e Brasil. Tempo Social, São Paulo, v. 11, n. 1, p. 177-188, 1999.

MACEDO, A. C. et al. Violência e desigualdade social: mortalidade por homicídios e condiçóes de vida em Salvador, Brasil. Revista de Saúde Pública, São Paulo, v. 35, n. 6, p. 515-522, 2001.

MACHADO, B. A.; PORTO, M. S. G. Homicídio na área metropolitana de Brasília: representaçóes sociais dos delegados de polícia, promotores de justiça e magistrados. Sociologias, Porto Alegre, v. 17, n. 40, p. 294-325, 2015.

. Violência e justiça criminal na área metropolitana de Brasília: dinâmicas organizacionais e representaçóes sociais. Tempo Social, São Paulo, v. 28, n. 3, p. 217-242, 2016.

MACHADO, C. "É muita mistura”: projetos religiosos, políticos, sociais, midiáticos, de saúde e segurança pública nas periferias do Rio de Janeiro. Religiäo \& Sociedade, Rio de Janeiro, v. 33, n. 2, p. 13-36, 2013. 
Pentecostalismo e o sofrimento do (ex-)bandido: testemunhos, mediaçôes, modos de subjetivação e projetos de cidadania nas periferias. Horizontes Antropológicos, Porto Alegre, v. 20, n. 42, p. 153-180, 2014.

MACHADO, E. P. Vítimas à deriva: processos sociais de vitimização de bancários por assaltos e sequestros. Caderno CRH, Salvador, v. 19, n. 47, p. 215-232, 2006.

MACHADO, E. P.; NORONHA, C. V. A polícia dos pobres: violência policial em classes populares urbanas. Sociologias, Porto Alegre, n. 7, p. 188-221, 2002.

MACHADO, L. Z. Masculinidade, sexualidade e estupro: as construções da virilidade. Cadernos Pagu, Campinas, n. 11, p. 231-273, 1998.

MACHADO DA SILVA, L. A. M. Sociabilidade violenta: por uma interpretação da criminalidade contemporânea no Brasil urbano. Sociedade e Estado, Brasília, DF, v. 19, n. 1, p. 53-84, 2004.

. "Violência urbana", segurança pública e favelas: o caso do Rio de Janeiro atual. Caderno CRH, Salvador, v. 23, n. 59, p. 283-300, 2010.

Polícia e violência urbana em uma cidade brasileira. Etnográfica, Lisboa, v. 15, p. 67-82, 2011.

A experiência das UPPs: uma tomada de posição. Dilemas, Rio de Janeiro, v. 8, n. 1, p. 7-24, 2015.

MACHADO DA SILVA, L. A. M.; LEITE, M. P. Violência, crime e polícia: o que os favelados dizem quando falam desses temas? Sociedade e Estado, Brasília, DF, v. 22, n. 3, p. 545-591, 2007.

MACIEL, L. R. Um lugar para aprisionar a loucura criminosa. História, Ciências, Saúde, Rio de Janeiro, v. 6, n. 2, p. 445-452, 1999.

MAGALHÃES, N. Significados de violência em abordagens da mensagem televisiva. Sociologias, Porto Alegre, n. 21, p. 318-343, 2009.

MALVASI, P. A. Entre a frieza, o cálculo e a "vida loka": violência e sofrimento no trajeto de um adolescente em cumprimento de medida socioeducativa. Saúde e Sociedade, São Paulo, v. 20, n. 1, p. 156-170, 2011 a.

Suspeito empreendedor de si: trajeto e sofrimento de um adolescente durante intervençấo socioeducativa. Etnográfica, Lisboa, v. 15, n. 3, p. 502-521, 2011 b.

MANSUR, T. S.; MACHADO, L. A. D. Problematizando a noçăo de "vítima" de violência. Psicologia \& Sociedade, Porto Alegre, v. 26, p. 183-192, 2014.

MARQUES, A. "Liderança”, "proceder" e "igualdade”: uma etnografia das relaçóes políticas no Primeiro Comando da Capital. Etnográfica, Lisboa, v. 14, n. 1, p. 311-335, 2010.

Do ponto de vista do "crime": notas de um trabalho de campo com "ladrōes". Horizontes Antropológicos, Porto Alegre, v. 22, n. 45, p. 335-367, 2016. 
MARQUES, A. C. D. R. Justiças e ajustes sociais. Civitas, Porto Alegre, v. 1, n. 2, p. 125-142, 2001.

MARQUES JUNIOR, G. A frustração profissional e a lei. Tempo Social, São Paulo, v. 22, n. 1, p. 127-147, 2010.

MARQUETTI, F. C.; ADORNO, R. C. F. Discursos e imagens da violência. Saúde e Sociedade, São Paulo, v. 23, n. 3, p. 749-763, 2014.

MARTINS, E. L. C. et al. O contraditório direito à saúde de pessoas em privação de liberdade: o caso de uma unidade prisional de Minas Gerais. Saúde e Sociedade, São Paulo, v. 23, n. 4, p. 1222-1234, 2014.

MARTINS, F. Sistema inquisitorial e a influência na formação da criminologia positivista no Brasil. Cadernos de Pesquisa, São Luís, v. 20, n. 3, p. 46-56, 2013.

MARTINS, S. H. Z. Produção e criminalidade: a construção de uma lógica. Revista de História, São Paulo, n. 132, p. 119-130, 1995.

MATTOS, C. S. "Parado na esquina": performances masculinas e identificaçôes entre "bondes" juvenis na Nova Holanda. Dilemas, Rio de Janeiro, v. 7, n. 4, p. 643-663, 2014.

. Uma etnografia da expansão do mundo do crime no Rio de Janeiro. Revista Brasileira de Ciências Sociais, São Paulo, v. 31, n. 91, p. e319110, 2016.

MEDEIROS, M. A. Aspectos institucionais da unificação das polícias no Brasil. Dados, Rio de Janeiro, v. 47, n. 2, p. 271-296, 2004.

MEIRELLES, Z. V.; MINAYO GOMEZ, C. Rompendo com a criminalidade: saída de jovens do tráfico de drogas em favelas na cidade do Rio de Janeiro. Ciência \& Saúde Coletiva, Rio de Janeiro, v. 14, n. 5, p. 1797-1805, 2009.

MELLO, K. S. S. Sofrimento e ressentimento: dimensōes da descentralização de políticas públicas de segurança no município de Niterói. Revista de Antropologia, São Paulo, v. 53, n. 2, p. 645-687, 2012.

MELO, J. L. B. O "velho" e o "novo" da violência rural na fronteira Brasil-Uruguai. Sociedade e Estado, Brasília, DF, v. 19, n. 1, p. 121-150, 2004.

MELO, M. C. B.; BARROS, É. N.; ALMEIDA, A. M. L. A representação da violência em adolescentes de escolas da rede pública de ensino do município do Jaboatão dos Guararapes. Ciência \& Saúde Coletiva, Rio de Janeiro, v. 16, n. 10, p. 4211-4221, 2011.

MELO, P. B. Mídia, consumo e crime na juventude: a construção de um traçado teórico. Caderno CRH, Salvador, v. 27, n. 70 , p. 151-164, 2014.

MELLO NETO, D. M. "Esquadrão da morte": uma outra categoria da acumulação social da violência no Rio de Janeiro. Dilemas, Rio de Janeiro, v. 10, n. 1, p. 132-162, 2017. 
MENDES, J. M. A dignidade das pertenças e os limites do neoliberalismo: catástrofes, capitalismo, Estado e vítimas. Sociologias, Porto Alegre, v. 18, n. 43, p. 58-86, 2016.

MENDONÇA FILHO, F. P. Velhos usuários e jovens traficantes? um estudo de caso sobre a atualização da nova Lei de Drogas na cidade do Rio de Janeiro. Dilemas, Rio de Janeiro, v. 6, n. 1, p. 11-37, 2013.

MENEGHEL, S. N.; HIRAKATA, V. N. Femicídios: homicídios femininos no Brasil. Revista de Saúde Pública, São Paulo, v. 45, n. 3, p. 564-574, 2011.

MENEZES, P. Tropa de elite: perigosas ambiguidades. Revista Brasileira de Ciências Sociais, Săo Paulo, v. 28, n. 81, p. 63-75, 2013.

MENEZES, P. R. M. et al. Enfrentamento da violência contra a mulher: articulação intersetorial e atenção integral. Saúde e Sociedade, São Paulo, v. 23, n. 3, p. 778-786, 2014.

MIAGUSKO, E. Esperando a UPP: circulação, violência e mercado político na Baixada Fluminense. Revista Brasileira de Ciências Sociais, São Paulo, v. 31, n. 91, p. e319101, 2016.

MINAHIM, M. A.; SPOSATO, K. B. A internação de adolescentes pela lente dos tribunais. Revista Direito GV, São Paulo, v. 7, n. 1, p. 277-298, 2011.

MINHOTO, L. D. As prisões do mercado. Lua Nova, São Paulo, n. 55-56, p. 133-154, 2002.

MIRANDA, A. E.; MERCON-DE-VARGAS, P. R.; VIANA, M. C. Saúde sexual e reprodutiva em penitenciária feminina, Espírito Santo, Brasil. Revista de Saúde Pública, São Paulo, v. 38, n. 2, p. 255-260, 2004.

MIRANDA, S. L. A construção de sentidos no método de execução penal Apac. Psicologia \& Sociedade, Belo Horizonte, v. 27, n. 3, p. 660-667, 2015.

MISSE, M. Sobre a acumulação social da violência no Rio de Janeiro. Civitas, Porto Alegre, v. 8, n. 3 p. 371-385, 2008.

. Crime, sujeito e sujeição criminal: aspectos de uma contribuição analítica sobre a categoria "bandido". Lua Nova, São Paulo, n. 79, p. 15-38, 2010a.

. O inquérito policial no Brasil: resultados gerais de uma pesquisa. Dilemas, Rio de Janeiro, v. 3, n. 7, p. 35-50, 2010 b.

O papel do inquérito policial no processo de incriminação no Brasil: algumas reflexôes a partir de uma pesquisa. Sociedade e Estado, Brasília, DF, v. 26, n. 1, p. 15-27, 2011.

Chandler no cinema noir: algumas reflexōes sobre "a simples arte de matar". Sociologias, Porto Alegre, v. 15, n. 34, p. 140-154, 2013.

MISSE, M.; GRILLO, C. C.; NERI, N. E. Letalidade policial e indiferença legal: a apuração judiciária dos "autos de resistência” no Rio de Janeiro (2001-2011). Dilemas, Rio de Janeiro, n. 1, p. 43-71, 2015. Edição especial. 
MITJAVILA, M. R. Medicalização, risco e controle social. Tempo Social, São Paulo, v. 27, n. 1, p. 117-137, 2015.

MITJAVILA, M. R.; MATHES, P. G. Doença mental e periculosidade criminal na psiquiatria contemporânea: estratégias discursivas e modelos etiológicos. Physis, Rio de Janeiro, v. 22, n. 4, p. 1377-1395, 2012.

Labirintos da medicalização do crime. Saúde e Sociedade, São Paulo, v. 25, n. 4, p. 847-856, 2016.

MONSMA, K.; TRUZZI, O.; CONCEIÇĀO, S. Solidariedade étnica, poder local e banditismo: uma quadrilha calabresa no oeste paulista, 1895-1898. Revista Brasileira de Ciências Sociais, São Paulo, v. 18, n. 53, p. 71-96, 2003.

MONTE, F. F. C. et al. Adolescentes autores de atos infracionais: psicologia moral e legislação. Psicologia \& Sociedade, Belo Horizonte, v. 23, n. 1, p. 125-134, 2011.

MONTEIRO, F. M. A seletividade do sistema prisional brasileiro e o perfil da populaçáo carcerária: um debate oportuno. Civitas, Porto Alegre, v. 13, n. 1, p. 93-117, 2013.

MOORE, H. L. Fantasias de poder e fantasias de identidade: gênero, raça e violência. Cadernos Pagu, Campinas, n. 14 , p. 13-44, 2000.

MORAES, C. S V. A normatizaçẫo da pobreza: crianças abandonadas e crianças infratoras. Revista Brasileira de Educação, Rio de Janeiro, n. 15, p. 70-96, 2000.

MOREIRA, A. P. G.; GUZZO, R. S. L. Violência e prevenção na escola: as possibilidades da psicologia da libertaçẫo. Psicologia \& Sociedade, Belo Horizonte, v. 29, p. e141683, 2017.

MOREIRA, D. P. et al. Exposição à violência entre adolescentes de uma comunidade de baixa renda no Nordeste do Brasil. Ciência \& Saúde Coletiva, Rio de Janeiro, v. 18, n. 5, p. 1273-1282, 2013.

MOREIRA, L. E.; TONELI, M. J. F. Paternidade, família e criminalidade: uma arqueologia entre o direito e a psicologia. Psicologia \& Sociedade, Belo Horizonte, v. 26, p. 36-46, 2014. Edição especial.

MOURÃO, A. N. M. Controle social informal e a responsabilização de jovens infratores. Caderno CRH, Salvador, v. 27, n. 71, p. 393-413, 2014.

MULLER, L. H. Bancos na favela: relaçôes entre agências bancárias e moradores de uma regiâo urbana alvo de políticas de pacificaçăo. Tempo Social, São Paulo, v. 29, n. 1, p. 89-107, 2017.

MUNIZ, B. B. Quem precisa de cultura? o capital existencial do funk e a conveniência da cultura. Sociologia \& Antropologia, Rio de Janeiro, v. 6, n. 2, p. 447-467, 2016.

MUNIZ, J. O. et al. Resistências e dificuldades de um programa de policiamento comunitário. Tempo Social, São Paulo, v. 9, n. 1, p. 197-213, 1997. 
MUNIZ, J. O.; SILVA, W. F. Mandato policial na prática: tomando decisōes nas ruas de João Pessoa. Caderno CRH, Salvador, v. 23, n. 60, p. 449-473, 2010.

NADANOVSKY, P. O aumento no encarceramento e a redução nos homicídios em São Paulo, Brasil, entre 1996 e 2005. Cadernos de Saúde Pública, Rio de Janeiro, v. 25, n. 8, p. 1859-1864, 2009.

NARDI, F. L.; HAUCK FILHO, N.; DELL'AGLIO, D. D. Preditores do comportamento antissocial em adolescentes. Psicologia: Teoria e Pesquisa, v. 32, n. 1, p. 63-70, 2016.

NEVES, E. B.; MELLO, M. G. S. O risco da profissão militar na cidade do Rio de Janeiro em "tempo de paz": a percepção da tropa. Ciência \& Saúde Coletiva, Rio de Janeiro, v. 14, n. 5, p. 1699-1707, 2009.

NEVES, P. S. C. Qual polícia para qual sociedade? o policiamento comunitário em Sergipe. Caderno CRH, Salvador, v. 18, n. 45 , p. $447-459,2005$.

NOBRE, M. T.; BARREIRA, C. Controle social e mediação de conflitos: as delegacias da mulher e a violência doméstica. Sociologias, Porto Alegre, n. 20, p. 138-163, 2008.

NÓBREGA JÚNIOR, J. M. A dinâmica dos homicídios no Nordeste e em Pernambuco. Dilemas, Rio de Janeiro, v. 3, n. 10, p. 51-74, 2010.

NOGUCHI, N. F. C.; DE LA TAILLE, Y. Universo moral de jovens internos da Febem. Cadernos de Pesquisa, São Paulo, v. 38, n. 133, p. 11-40, 2008.

NORTE, C. E. As vítimas da violência: entre discursos científicos e biopolíticas do contemporâneo. Psicologia \& Sociedade, Belo Horizonte, v. 27, n. 1, p. 169-178, 2015.

NOTO, A. R.; GALDUROZ, J. C. F. O uso de drogas psicotrópicas e a prevençấo no Brasil. Ciência \& Saúde Coletiva, Rio de Janeiro, v. 4, n. 1, p. 145-151, 1999.

NUNES, B. F. Distrito Federal e Brasília: dinâmica urbana, violência e heterogeneidade social. Cadernos Metrópole, São Paulo, n. 17, p. 35-57, 2007.

NUNES, E. L. G.; ANDRADE, A. G. Adolescentes em situação de rua: prostituição, drogas e HIV/AIDS em Santo André, Brasil. Psicologia \& Sociedade, Belo Horizonte, v. 21, n. 1, p. 45-54, 2009.

NUNES, M. Idiomas culturais como estratégias populares para enfrentar a violência urbana. Ciência \& Saúde Coletiva, Rio de Janeiro, v. 10, n. 2, p. 409-418, 2005.

OLIVEIRA, A. As peças e os mecanismos do crime organizado em sua atividade tráfico de drogas. Dados, Rio de Janeiro, v. 50, n. 4, p. 699-720, 2007.

A dinâmica da criminalidade organizada no Brasil a partir das operaçóes da Polícia Federal. Dilemas, Rio de Janeiro, v. 5, n. 3, p. 423-446, 2012. 
OLIVEIRA, A. S. A violência e a criminalidade como entraves à democratização da sociedade brasileira. Caderno CRH, Salvador, n. 38, p. 239-265, 2003.

O policiamento e a democracia. Organizaçôes \& Sociedade, Salvador, v. 12, n. 33, p. 129-148, 2005 a.

Uma polícia militar em uma sociedade democrática. Caderno CRH, Salvador, v. 18, n. 44, p. 281-298, 2005 b.

Crime, controle do crime e governança democrática. Dilemas, Rio de Janeiro, v. 2, n. 5-6, p. 49-78, 2010.

OLIVEIRA, D. C. C.; RUSSO, J. A. Abuso sexual infantil em laudos psicológicos: as "duas psicologias”. Physis, Rio de Janeiro, v. 27, n. 3, p. 579-604, 2017.

OLIVEIRA, E. C. Apontamentos para uma sociologia da valentia. Sociologias, Porto Alegre, v. 18, n. 43, p. 336-362, 2016.

OLIVEIRA, F. L.; SILVA, V. F. Processos judiciais como fonte de dados: poder e interpretação. Sociologias, Porto Alegre, n. 13 , p. 244-259, 2005.

OLIVEIRA, M. P. P. Sobre armadilhas e cascas de banana: uma análise crítica da administração de justiça em temas associados aos direitos humanos. Cadernos Pagu, Campinas, n. 31, p. 125-149, 2008.

OLIVEIRA, W. F. Violência e saúde coletiva: contribuiçóes teóricas das ciências sociais à discussão sobre o desvio. Saúde e Sociedade, São Paulo, v. 17, n. 3, p. 42-53, 2008.

OLIVEIRA JÚNIOR, H. R. Reflexôes sobre o estudo da proliferação de condomínios fechados: críticas e sugestôes. Cadernos Metrópole, São Paulo, n. 20, p. 221-239, 2008.

OSHIKATA, C. T. Características das mulheres violentadas sexualmente e da adesão ao seguimento ambulatorial: tendências observadas ao longo dos anos em um serviço de referência em Campinas, São Paulo, Brasil. Cadernos de Saúde Pública, Rio de Janeiro, v. 27, n. 4, p. 701-713, 2011.

PACHECO, J. T. B.; HUTZ, C. S. Variáveis familiares preditoras do comportamento anti-social em adolescentes autores de atos infracionais. Psicologia: Teoria e Pesquisa, Brasília, DF, v. 25, n. 2, p. 213-219, 2009.

PACHECO, R. A. S.; PRADO, R. C. O.; KADWEU, E. V. População carcerária indígena e o direito à diferença: o caso do município de Dourados, MS. Revista Direito GV, São Paulo, v. 7, n. 2, p. 469-500, 2011.

PAES-MACHADO, E. Assaltantes a bordo: violência, insegurança e saúde no trabalho em transporte coletivo de Salvador, Bahia, Brasil. Cadernos de Saúde Pública, Rio de Janeiro, v. 18, n. 5, p. 1215-1227, 2002.

PAES-MACHADO, E.; RICCIO-OLIVEIRA, M. A. O jogo de esconde-esconde: trabalho perigoso e ação social defensiva entre motoboys de Salvador. Revista Brasileira de Ciências Sociais, São Paulo, v. 24, n. 70, p. 91-106, 2009.

PAES-MACHADO, E.; VIODRES-INOUE, S. O lado sombrio da estrada: vitimização, gestão coercitiva e percepção de medo nos roubos a ônibus interurbanos. Revista Brasileira de Ciências Sociais, São Paulo, v. 30, n. 89, p. 9-30, 2015. 
PAIVA, L. F. À espera de respostas: reflexões sobre o trabalho da Justiça Criminal. Dilemas, Rio de Janeiro, v. 2, n. 4, p. 49-82, 2009.

PAIXÃO, A. C. W.; DESLANDES, S. F. Análise das políticas públicas de enfrentamento da violência sexual infantojuvenil. Saúde e Sociedade, São Paulo, v. 19, n. 1, p. 114-126, 2010.

PAIXĀO, A. L.; BEATO FILHO, C. C. Crimes, vítimas e policiais. Tempo Social, São Paulo, v. 9, n. 1, p. 233-248, 1997.

PALAZZO, L. S. et al. Violência física e fatores associados: estudo de base populacional no sul do Brasil. Revista de Saúde Pública, São Paulo, v. 42, n. 4, p. 622-629, 2008.

PASINATO, W. Lei Maria da Penha: novas abordagens sobre velhas propostas: onde avançamos? Civitas, Porto Alegre, v. 10, n. 2, p. 216-232, 2010.

. "Femicídios" e as mortes de mulheres no Brasil. Cadernos Pagu, Campinas, n. 37, p. 219-246, 2011.

PASTANA, D. R. Estado punitivo brasileiro: a indeterminação entre democracia e autoritarismo. Civitas, Porto Alegre, v. 13, n. 1, p. $27-47,2013$.

PAULA, L. Da "questão do menor" à garantia de direitos: discursos e práticas sobre o envolvimento de adolescentes com a criminalidade urbana. Civitas, Porto Alegre, v. 15, n. 1, p. 27-43, 2015.

PAZINATO, E.; KERBER, A.; DAL SANTO, R. Observatório de Segurança Pública de Canoas: contribuições à gestâo pública municipal da segurança. Civitas, Porto Alegre, v. 13, n. 1, p. 77-92, 2013.

PENNA PIRES, Á. Alguns obstáculos a uma mutação "humanista" do direito penal. Sociologias, Porto Alegre, n. 1, p. 64-95, 1999.

PENNA, P. D. M.; BELO, F. R. R. Crítica à alteraçấo da Lei Maria da Penha: tutela e responsabilidade. Psicologia: Teoria e Pesquisa, Brasília, DF, v. 32, n. 3, p. e323224, 2016.

PEREIRA, P. C.; SANTOS, A. B.; WILLIAMS, L. C. A. Desempenho escolar da criança vitimizada encaminhada ao fórum judicial. Psicologia: Teoria e Pesquisa, Brasília, DF, v. 25, n. 1, p. 19-28, 2009.

PERES, C. A. et al. Prevençấo da aids com adolescentes encarcerados em São Paulo, SP. Revista de Saúde Pública, São Paulo, v. 36, n. 4, p. 76-81, 2002. Suplemento 1.

PERES, M. F. T. A doença mental no direito penal brasileiro: inimputabilidade, irresponsabilidade, periculosidade e medida de segurança. História, Ciências, Saúde, Rio de Janeiro, v. 9, n. 2. p. 335-355, 2002.

PERES, M. F. T.; SANTOS, P. C. Mortalidade por homicídios no Brasil na década de 90: o papel das armas de fogo. Revista de Saúde Pública, São Paulo, v. 39, n. 1, p. 58-66, 2005. 
PETRY, H.; NASCIMENTO, D. M. “Tá com dó? leva pra casa!": análise dos discursos favoráveis à redução da maioridade penal em rede social. Psicologia: Ciência e Profissão, Brasília, DF, v. 36, n. 2, p. 426-438, 2016.

PICANÇO, F. S.; LOPES, N. O tráfico de drogas em formas: notas de pesquisa sobre o Rio de Janeiro. Análise Social, Lisboa, n. 218, p. 96-120, 2016.

PIMENTA, M. M. Masculinidades e sociabilidades: compreendendo o envolvimento de jovens com violência e criminalidade. Dilemas, Rio de Janeiro, v. 7, n. 3, p. 701-730, 2014.

Relaçôes de poder e controle social em áreas de grande exposição à violência. Civitas, Porto Alegre, v. 15, n. 1, p. 84-104, 2015.

PINHEIRO, A. S. A polícia corrupta e violenta: os dilemas civilizatórios nas práticas policiais. Sociedade e Estado, Brasília, DF, v. 28, n. 2, p. 323-349, 2013.

PINHEIRO, P. A violência do Rio às portas da emergência. Cadernos de Saúde Pública, Rio de Janeiro, v. 10, p. S223-S225, 1994. Suplemento 1.

PINHEIRO, P. S. Violência, crime e sistemas policiais em países de novas democracias. Tempo Social, São Paulo, v. 9, n. 1, p. 43-52, 1997.

PINO, A. Violência, educação e sociedade: um olhar sobre o Brasil contemporâneo. Educação \& Sociedade, Campinas, v. 28, n. 100, p. $763-785,2017$.

PIRES, A. P.; CAUCHIE, J.-F. Um caso de inovaçấo "acidental” em matéria de penas: a lei brasileira de drogas. Revista Direito GV, São Paulo, v. 7, n. 1, p. 299-330, 2011.

PISCITELLI, A. Entre as "máfias" e a "ajuda”: a construção de conhecimento sobre tráfico de pessoas. Cadernos Pagu, Campinas, n. 31, p. 29-63, 2008.

Economias sexuais, amor e tráfico de pessoas: novas questóes conceituais. Cadernos Pagu, Campinas, n. 47, p. e16475, 2016.

. "\#Queroviajarsozinhasemmedo": novos registros das articulaçôes entre gênero, sexualidade e violência no Brasil. Cadernos Pagu, Campinas, n. 50, p. e175008, 2017.

PONCIONI, P. O modelo policial profissional e a formação profissional do futuro policial nas academias de polícia do estado do Rio de Janeiro. Sociedade e Estado, Brasília, DF, v. 20, n. 3, p. 585-610, 2005.

PORTELLA, A. P. Análise configuracional de homicídios: velhas e novas situaçóes de violência letal contra as mulheres em Recife. Dilemas, Rio de Janeiro, v. 4, n. 3, p. 403-439, 2011.

PORTELLA, A. P.; RATTON, J. L. A teoria social feminista e os homicídios: o desafio de pensar a violência letal contra as mulheres. Contemporânea, São Carlos, v. 5, n. 1, p. 93-118, 2015. 
PORTO, M. S. G. A violência entre a inclusão e a exclusão social. Tempo Social, São Paulo, v. 12, n. 1, p. 187-200, 2000.

Violência e meios de comunicação de massa na sociedade contemporânea. Sociologias, Porto Alegre, n. 8, p. 152-171, 2002.

Crenças, valores e representaçōes sociais da violência. Sociologias, Porto Alegre, n. 16, p. 250-273, 2006.

Brasília, uma cidade como as outras? representaçóes sociais e práticas de violência. Sociedade e Estado, Brasília, DF, v. 24, n. 3, p. 797-826, 2009 a.

Mídia, segurança pública e representaçóes sociais. Tempo Social, São Paulo, v. 21, n. 2, p. 211-233, 2009b.

Pensando segurança pública no Brasil: desafios para a pesquisa. Revista Brasileira de Sociologia, São Cristóvão, v. 1, n. 2, p. 275-297, 2014.

A violência, entre práticas e representaçóes sociais: uma trajetória de pesquisa. Sociedade e Estado, Brasília, DF, v. 30, n. 1, p. 19-37, 2015.

POSSAS, M. T. Produção de leis criminais e racionalidade penal moderna: uma análise da distinção "conservador" x "progressista" no caso da criação da lei contra a tortura no Brasil. Dilemas, Rio de Janeiro, v. 8, n. 3, p. 473-499, 2015.

POSSAS, M. T.; ROCHA, T. T. "A onça comeu o suspeito": reflexóes sobre o rule of law no Acre entre os anos 1980 e 2000. Lua Nova, São Paulo, n. 91, p. 229-268, 2014.

PRIULI, R. M. A.; MORAES, M. S. Adolescentes em conflito com a lei. Ciência \& Saúde Coletiva, Rio de Janeiro, v. 12 , n. 5 , p. $1185-1192,2007$.

RAFAEL, A. As armas do crime: reflexôes sobre o tráfico de drogas no Rio de Janeiro. Civitas, Porto Alegre, v. 1, n. 2, p. 165-180, 2001.

RAMOS, J. S. Resenhas e críticas bibliográficas: os muitos sentidos da identificação criminal. Physis, Rio de Janeiro, v. 13, n. 2, p. 149-160, 2003.

RAMOS, S. Respostas brasileiras à violência e novas mediaçóes: o caso do grupo cultural AfroReggae e a experiência do projeto Juventude e Polícia. Ciência \& Saúde Coletiva, Rio de Janeiro, v. 11, p. 1303-1311, 2006. Suplemento 1.

RATTON, J. L.; GALVÃO, C. Para além da maldade, da loucura e da vitimizaçáo. Civitas, Porto Alegre, v. 16, n. 1, p. 26-41, 2016.

RATTON, J. L.; TORRES, V.; BASTOS, C. Inquérito policial, sistema de justiça criminal e políticas públicas de segurança: dilemas e limites da governança. Sociedade e Estado, Brasília, DF, v. 26, n. 1, p. 29-58, 2011.

RAUTER, C. Clínica e estratégias de resistência: perspectivas para o trabalho do psicólogo em prisōes. Psicologia \& Sociedade, Belo Horizonte, v. 19, n. 2, p. 42-47, 2017. 
REBELO, F; CAPONI, S. O gabinete do doutor Edelvito Campelo D’Araújo: a penitenciária Pedra Grande como espaço de construção de um saber (1933-1945). História, Ciências, Saúde, Rio de Janeiro, v. 14, n. 4, p. 1217-1238, 2017.

RÊGO, X.; FERNANDES, L. As falas do medo: convergências entre as cidades do Porto e Rio de Janeiro. Revista Brasileira de Ciências Sociais, São Paulo, v. 27, n. 78, p. 51-65, 2012.

RIBEIRO, E. Vitimização letal e desigualdade no Brasil: evidências em nível municipal. Civitas, Porto Alegre, v. 16, n. 2, p. 285-305, 2016.

RIBEIRO, F. M. L.; MINAYO, M. C. S. O papel da religiaão na promoção da saúde, na prevençấo da violência e na reabilitação de pessoas envolvidas com a criminalidade. Ciência \& Saúde Coletiva, Rio de Janeiro, v. 19, n. 6, p. 1773-1789, 2014.

RIBEIRO, G. L. A globalização popular e o sistema mundial não hegemônico. Revista Brasileira de Ciências Sociais, São Paulo, v. 25, n. 74, p. 21-38, 2017.

RIBEIRO, L. M. L. A produção decisória do sistema de justiça criminal para o crime de homicídio: análise dos dados do estado de São Paulo entre 1991 e 1998. Dados, Rio de Janeiro, v. 53, n. 1, p. 159-194, 2010a.

O tempo da justiça criminal. Porto Alegre: Civitas, $2010 \mathrm{~b}$.

O nascimento da polícia moderna: uma análise dos programas de policiamento comunitário implementados na cidade do Rio de Janeiro (1983-2012). Análise Social, Lisboa, n. 211, p. 272-309, 2014.

RIBEIRO, L. M. L.; DUARTE T. O tempo dos Tribunais do Júri no Rio de Janeiro: os padróes de seleção e filtragem para homicídios dolosos julgados entre 2000 e 2007. Dilemas, Rio de Janeiro, v. 2, n. 3, p. 11-37, 2009.

RIBEIRO, L. M. L.; MACHADO, I. S. Repressão, autonomia e responsividade: o direito que se exerce nas delegacias de polícia no Brasil. Sociedade e Estado, Brasília, DF, v. 29, n. 1, p. 153-180, 2014.

RIBEIRO, L. M. L.; MACHADO, I. S.; SILVA, K. A. A reforma processual penal de 2008 e a efetivação dos direitos humanos do acusado. Revista Direito GV, São Paulo, v. 8, n. 2, p. 677-702, 2012a.

. Tempo na ou da justiça criminal brasileira: uma discussão metodológica. Opinião Pública, Campinas, v. 18, n. 2, p. 355-382, 2012 b.

RIBEIRO, L. M. L.; ROCHA, R. L. S.; COUTO, V. A. Nas malhas da justiça: uma análise dos dados oficiais de indiciados por drogas em Belo Horizonte (2008-2015). Opiniāo Pública, Campinas, v. 23, n. 2, p. 397-428, 2017.

RIBEIRO, L. M. L.; SOUSA, A. S. Encruzilhadas da participação popular na modernização das políticas públicas de segurança. Civitas, Porto Alegre, v. 11, n. 1, p. 115-134, 2011.

RIFIOTIS, T. As delegacias especiais de proteção à mulher no Brasil e a “judiciarização" dos conflitos conjugais. Sociedade e Estado, Brasília, DF, v. 19, n. 1, p. 85-119, 2004. 
RIFIOTIS, T.; VENTURA, A. B.; CARDOSO, G. R. Reflexôes críticas sobre a metodologia do estudo do fluxo de justiça criminal em caso de homicídios dolosos. Revista de Antropologia, São Paulo, v. 53, n. 2, p. 689-714, 2012.

ROCHA, A. P. Policiamento democrático no Brasil: enquadramentos teóricos e desilusões empíricas: um estudo das polícias do Distrito Federal. Civitas, Porto Alegre, v. 13, n. 1, p. 56-76, 2013.

ROCHA, A. F. O. Crime, violência e controle social como produtos culturais: novas perspectivas para o debate. Dilemas, Rio de Janeiro, v. 10, n. 1, p. 48-62, 2017.

ROCHA, L. M. “O morro está na calmaria”: mídia impressa e o repertório da paz no contexto da pacificação. Dilemas, Rio de Janeiro, v. 8, n. 1, p. 25-40, 2015.

ROCHA, R. L. S. A guerra como forma de relação: uma análise das rivalidades violentas entre gangues em um aglomerado de Belo Horizonte. Dilemas, Rio de Janeiro, v. 8, n. 2, p. 277-301, 2015.

ROCHA, R. M. G.; PEREIRA, D. L.; DIAS, T. M. O contexto do uso de drogas entre travestis profissionais do sexo. Saúde e Sociedade, São Paulo, v. 22, n. 2, p. 554-565, 2013.

RODRIGUES, D. R. S. R.; CONCEIÇÃO, M. I. G.; IUNES, A. L. S. Representaçôes sociais do crack na mídia. Psicologia: Teoria e Pesquisa, Brasília, DF, v. 31, n. 1, p. 115-123, 2015.

RODRIGUES, H. Vidas em fuga: juventude e justiça criminal. Revista Brasileira de Ciências Sociais, São Paulo, v. 32, n. 93, p. e329313, 2017.

RODRIGUES, M. T. O sistema de justiça criminal e a prostituição no Brasil contemporâneo: administração de conflitos, discriminação e exclusão. Sociedade e Estado, Brasília, DF, v. 19, n. 1, p. 151-172, 2004.

ROJO, R. E.; AZEVEDO, R. G. Sociedade, direito, justiça: relaçôes conflituosas, relaçóes harmoniosas? Sociologias, Porto Alegre, n. 13, p. 16-34, 2005.

ROLIM, R. C. Justiça criminal e condiçấo feminina na capital da república em meados do século XX. Sociedade e Estado, Brasília, DF, v. 22, n. 1, p. 97-133, 2007.

ROQUE, E. M. S. T. et al. Sistemas de justiça e a vitimização secundária de crianças e ou adolescentes acometidas de violência sexual intrafamiliar. Saúde e Sociedade, São Paulo, v. 23, n. 3, p. 801-813, 2014.

ROSA, A. R.; BRITO, M. J. Ensaio sobre violência simbólica nas organizaçôes. Organizaçôes \& Sociedade, Salvador, v. 16, n. 51, p. 629-646, 2009.

ROSA, E. M. et al. Violência urbana, insegurança e medo: da necessidade de estratégias coletivas. Psicologia: Ciência e Profissão, Brasília, DF, v. 32, n. 4, p. 826-839, 2017.

RUDNICKI, D. O ingresso de bacharéis em direito na polícia militar gaúcha. Sociologias, Porto Alegre, n. 20, p. $108-137,2008$. 
RUMIN, C. R. Sofrimento na vigilância prisional: o trabalho e a atençẫo em saúde mental. Psicologia: Ciência e Profissão, Brasília, DF, v. 26, n. 4, p. 570-581, 2006.

RUOTTI, C. et al. Graves violaçōes de direitos humanos e desigualdade no município de São Paulo. Revista de Saúde Pública, São Paulo, v. 43, n. 3, p. 533-540, 2009.

. A vulnerabilidade dos jovens à morte violenta: um estudo de caso no contexto dos "Crimes de Maio". Saúde e Sociedade, São Paulo, v. 23, n. 3, p. 733-748, 2014.

SAFFIOTI, H. I. B. Contribuiçōes feministas para o estudo da violência de gênero. Cadernos Pagu, Campinas, n. 16, p. 115-136, 2001.

SALLA, F. As rebeliôes nas prisôes: novos significados a partir da experiência brasileira. Sociologias, Porto Alegre, n. 16, p. 274-307, 2006.

SAllA, F.; ALVAREZ, M. C. Paulo Egídio e a sociologia criminal em São Paulo. Tempo Social, São Paulo, v. 12, n. 1, p. 101-122, 2000.

SALLA, F; GAUTO, M.; ALVAREZ, M. C. A contribuição de David Garland: a sociologia da punição. Tempo Social, São Paulo, v. 18, n. 1, p. 329-350, 2006.

SANCHES, S.; DUARTE, S. J. H.; PONTES, E. R. J. C. Caracterização das vítimas de ferimentos por arma de fogo, atendidas pelo Serviço de Atendimento Móvel de Urgência em Campo Grande-MS. Saúde e Sociedade, São Paulo, v. 18, n. 1, p. 95-102, 2009.

SANT'ANNA, A.; AERTS, D.; LOPES, M. J. Homicídios entre adolescentes no sul do Brasil: situaçôes de vulnerabilidade segundo seus familiares. Cadernos de Saúde Pública, Rio de Janeiro, v. 21, n. 1, p. 120-129, 2005.

SANTELLI, I. H. S. Da sociologia do desvio à criminologia crítica: os indígenas de Mato Grosso do Sul como outsiders. Ciências Sociais Unisinos, São Leopoldo, v. 50, n. 1, p. 65-76, 2014.

SANTOS, A. M. V. Pais encarcerados: filhos invisíveis. Psicologia: Ciência e Profissão, Brasília, DF, v. 26, n. 4, p. 594-603, 2006.

SANTOS, H. Mulheres como autoras de violência: evidências e agenda de pesquisa. Civitas, Porto Alegre, v. 16, n. 1, p. 42-58, 2016.

SANTOS, H. B.; NARDI, H. C. Masculinidades entre matar e morrer: o que a saúde tem a ver com isso? Physis, Rio de Janeiro, v. 24, n. 3, p. 931-949, 2014.

SANTOS, J. V. T. A arma e a flor: formação da organização policial, consenso e violência. Tempo Social, São Paulo, v. 9 , n. 1, p. 155-167, 1997.

.Violências, América Latina: a disseminação de formas de violência e os estudos sobre conflitualidades. Sociologias, Porto Alegre, n. 8, p. 16-32, 2002. 
SANTOS, J. V. T.; TEIXEIRA, A. N. Figuraçôes da violência: uma apresentaçâo enigmática. Sociologias, Porto Alegre, v. 15 , n. 34 , p. $14-25,2013$.

SANTOS, M. F. S.; ALESSIO, R. L. S. SILVA, J. M. M. N. Os adolescentes e a violência na imprensa. Psicologia: Teoria e Pesquisa, Brasília, DF, v. 25, n. 3, p. 447-452, 2009.

SANTOS, M. S. A invisibilidade da pena: Dois Rios como imagem do paraíso. Tempo Social, São Paulo, v. 28, n. 2, p. 261-283, 2016.

SANTOS, S. D. M. Da redução da idade penal à equação do tempo: notas críticas contra as propostas que rechaçam princípios constitucionais. Educação \& Sociedade, Campinas, v. 36, n. 133, p. 909-926, 2015.

SANTOS, S. M.; SILVEIRA, A. M. Os desafios de um projeto de prevenção à violência e à criminalidade: o Mulheres da Paz em Santa Luzia/MG. Estudos Feministas, Florianópolis, v. 23, n. 1, p. 99-118, 2015.

SAPORI, L. F. Mercado do crack e violência urbana na cidade de Belo Horizonte. Dilemas, Rio de Janeiro, v. 5, n. 1, p. 37-66, 2012.

SAPORI, L. F.; SANTOS, R. F.; MAAS, L. W. D. Fatores sociais determinantes da reincidência criminal no Brasil: o caso de Minas Gerais. Revista Brasileira de Ciências Sociais, São Paulo, v. 32, n. 94, p. 1-18, 2017.

SARTI. C. A vítima como figura contemporânea. Caderno CRH, Salvador, v. 24, n. 61, p. 51-61, 2011.

SCHABBACH, L. M. Sistema penitenciário do Rio Grande do Sul: reincidência e reincidentes prisionais. Sociologias, Porto Alegre, n. 1, p. 224-243, 1999.

. Exclusão, ilegalidades e organizaçốes criminosas no Brasil. Sociologias, Porto Alegre, n. 20, p. 48-71, 2008.

O crime organizado em perspectiva mundial. Sociologias, Porto Alegre, v. 15, n. 34, p. 278-293, 2013.

SCHAEFER, L. S.; ROSSETTO, S.; KRISTENSEN, C. H. Perícia psicológica no abuso sexual de crianças e adolescentes. Psicologia: Teoria e Pesquisa, Brasília, DF, v. 28, n. 2, p. 227-234, 2012.

SCHRITZMEYER, A. L. P. Etnografia dissonante dos tribunais do júri. Tempo Social, São Paulo, v. 19, n. 2, p. 111-129, 2007.

SCISLESKI, A. C. C. et al. Medida socioeducativa de internação: dos corpos dóceis às vidas nuas. Psicologia: Ciência e Profissão, Brasília, DF, v. 34, n. 3, p. 660-675, 2014.

SEBASTIĀO, J. Violência na escola, processos de socialização e formas de regulação. Sociologia, Problemas e Práticas, Lisboa, n. 71, p. 23-37, 2013.

SENTO-SÉ, J. T. Prevenção ao crime e teoria social. Lua Nova, São Paulo, n. 83, p. 9-40, 2011. 
SENTO-SÉ, J. T.; COELHO, M. C. Sobre errâncias, imprecisões e ambivalências: notas sobre as trajetórias de jovens cariocas e sua relaçẫo com o mundo do crime. Horizontes Antropológicos, Porto Alegre, v. 20, n. 42, p. 327-357, 2014.

SEQUEIRA, V. C. Uma vida que não vale nada: prisão e abandono político-social. Psicologia: Ciência e Profissão, Brasília, DF, v. 26, n. 4, p. 660-671, 2006.

Pedro e o lobo: o criminoso perverso e a perversão social. Psicologia: Teoria e Pesquisa, Brasília, DF, v. 25, n. 2, p. 221-228, 2009.

SERPA, M. G. Perspectivas sobre papéis de gênero masculino e feminino: um relato de experiência com mães de meninas vitimizadas. Psicologia \& Sociedade, Belo Horizonte, v. 22, n. 1, p. 14-22, 2010.

SERRA. O. Consideraçóes sobre a violência fria. Caderno CRH, Salvador, v. 29, n. 76, p. 119-131, 2016.

SILVA JUNIOR, G. B. et al. Identificação e notificação de maus-tratos em crianças e adolescentes por médicos de família no Ceará. Trabalho, Educação e Saúde, Rio de Janeiro, v. 15, n. 2, p. 469-484, 2017.

SILVA, B. F. A.; BEATO FILHO, C. C. Ecologia social do medo: avaliando a associaçáo entre contexto de bairro e medo de crime. Revista Brasileira de Estudos de População, Rio de Janeiro, v. 30, p. S155-S170, 2013. Suplemento 1.

SILVA, C. J. P. et al. A violência urbana contra crianças e adolescentes em Belo Horizonte: uma história contada através dos traumas maxilofaciais. Physis, Rio de Janeiro, v. 21, n. 3, p. 1103-1120, 2011.

SILVA, G. F.; BEATO, C. Confiança na polícia em Minas Gerais: o efeito da percepção de eficiência e do contato individual. Opinião Pública, Campinas, v. 19, n. 1, p. 118-153, 2013.

SILVA, J. Representação e ação dos operadores do sistema penal no Rio de Janeiro. Tempo Social, São Paulo, v. 9, n. 1, p. 95-114, 1997.

SILVA, J. L. et al. Associaçōes entre bullying escolar e conduta infracional: revisão sistemática de estudos longitudinais. Psicologia: Teoria e Pesquisa, Brasília, DF, v. 32, n. 1, p. 81-90, 2016.

SILVA, J. P. Poder e direito em Foucault: relendo Vigiar e punir 40 anos depois. Lua Nova, São Paulo, n. 97, p. 139-171, 2016.

SILVA, K. A. O papel dos tipos de homicídios dolosos na construçấo social da incriminaçăo dos sujeitos pelos promotores de justiça: Belo Horizonte, processos com andamento entre 2007 e 2009. Dilemas, Rio de Janeiro, v. 3, n. 8, p. 101-123, 2010.

SILVA, L. S. Anos potenciais de vida perdidos por mulheres vítimas de homicídio na cidade do Recife, Pernambuco, Brasil. Cadernos de Saúde Pública, Rio de Janeiro, v. 27, n. 9, p. 1721-1730, 2011.

SILVA, M. B.; VIEIRA, S. B. O processo de trabalho do militar estadual e a saúde mental. Saúde e Sociedade, São Paulo, v. 17, n. 4, p. 161-170, 2008. 
SILVA, R.; MOREIRA, F. A.; OLIVEIRA, C. B. F. Ciências, trabalho e educação no sistema penitenciário brasileiro. Cadernos Cedes, Campinas, v. 36, n. 98, p. 9-24, 2016.

SILVA, R. A. Direitos humanos e polícia. Civitas, Porto Alegre, v. 8, n. 3, p. 454-465, 2008.

SILVA, W. V.; HUNING, S. M. Dispositivo das drogas e governo da vida. Psicologia \& Sociedade, Belo Horizonte, v. 29, p. 1-11, 2017.

SILVEIRA, A. M. A prevenção de homicídios: a experiência do programa Fica Vivo no Morro das Pedras. Educação \& Realidade, Porto Alegre, v. 33, p. 163-173, 2008.

SILVEIRA, A. M. et al. Impacto do programa Fica Vivo na redução dos homicídios em comunidade de Belo Horizonte. Revista de Saúde Pública, São Paulo, v. 44, n. 3, p. 496-502, 2010.

SIMIÃO, D. S.; OLIVEIRA, L. R. C. Judicialização e estratégias de controle da violência doméstica: a suspensão condicional do processo no Distrito Federal entre 2010 e 2011. Sociedade e Estado, Brasília, DF, v. 31, n. 3, p. 845-874, 2016.

SINHORETTO, J. Corpos do poder: operadores jurídicos na periferia de São Paulo. Sociologias, Porto Alegre, n. 13, p. 136-161, 2005.

. Reforma da justiça: estudo de caso. Tempo Social, São Paulo, v. 19, n. 2, p. 157-177, 2007.

. Controle social estatal e organização do crime em São Paulo. Dilemas, Rio de Janeiro, v. 7, n. 1, p. 167-196, 2014.

SINHORETTO, J.; LIMA, R. S. Narrativa autoritária e pressōes democráticas na segurança pública e no controle do crime. Contemporânea, São Carlos, v. 5, n. 1, p. 119-141, 2015.

SINHORETTO, J.; SILVESTRE, G.; MELO, F. A. L. O encarceramento em massa em São Paulo. Tempo Social, São Paulo, v. 25, n. 1, p. 83-106, 2013.

SOARES, B. M. A "conflitualidade" conjugal e o paradigma da violência contra a mulher. Dilemas, Rio de Janeiro, v. 5, n. 2, p. 191-210, 2012.

SOARES, G. A. D. Matar e, depois, morrer. Opinião Pública, Campinas, v. 8, n. 2, p. 275-303, 2002.

SOARES, G. A. D.; MIRANDA, D. Gênero e trauma. Sociedade e Estado, Brasília, DF, v. 20, n. 1, p. 135-162, 2005a. . As co-variatas políticas das mortes violentas. Opiniāo Pública, Campinas, v. 11, n. 1, p. 192-212, 2005b.

SOARES FILHO, M. M. Direito à saúde mental no sistema prisional: reflexōes sobre o processo de desinstitucionalização dos HCTP. Ciência \& Saúde Coletiva, Rio de Janeiro, v. 21, n. 7, p. 2101-2110, 2016.

SOARES FILHO, M. M.; BUENO, P. M. M. G. Demografia, vulnerabilidades e direito à saúde da população prisional brasileira. Ciência \& Saúde Coletiva, Rio de Janeiro, v. 21, n. 7, p. 1999-2010, 2016. 
SORJ, B.; GOMES, C. O gênero da "nova cidadania": o programa Mulheres da Paz. Sociologia \& Antropologia, Rio de Janeiro, v. 1, n. 2, p. 147-164, 2011.

SOUZA, A. P. L.; LAUDA, B. V.; KOLLER, S. H. Opiniōes e vivências de adolescentes acerca dos direitos ao respeito e privacidade e à proteçấo contra a violência física no âmbito familiar. Psicologia \& Sociedade, Belo Horizonte, v. 26, n. 2, p. 397-409, 2014.

SOUZA, E. R.; LIMA, M. L. C. Panorama da violência urbana no Brasil e suas capitais. Ciência \& Saúde Coletiva, Rio de Janeiro, v. 11, p. 1211-1222, 2006. Suplemento 1.

SOUZA, F. M. et al. A violência urbana e suas consequências em um centro de atenção psicossocial na zona norte do município do Rio de Janeiro. Saúde e Sociedade, São Paulo, v. 20, n. 2, p. 363-376, 2011.

SOUZA, G. A. D.; AZEVEDO, R. G. Alternativas penais no Brasil após 1984 e seus efeitos: uma análise a partir de discursos sobre crime e punição. Contemporânea, São Carlos, v. 5, n. 1, p. 69-92, 2015.

SOUZA, L. A. F. Ordem social, polícia civil e justiça criminal na cidade de São Paulo (1889-1930). Revista de História, São Paulo, n. 162, p. 179-204, 2010.

. Dispositivo militarizado da segurança pública: tendências recentes e problemas no Brasil. Sociedade e Estado, Brasília, DF, v. 30, n. 1, p. 207-223, 2015.

SOUZA, R. T. Três teses sobre a violência: violência e alteridade no contexto contemporâneo: algumas consideraçóes filosóficas. Civitas, Porto Alegre, v. 1, n. 2, p. 7-10, 2001.

SOUZA, T. O.; SOUZA, E. R.; PINTO, L. W. Evolução da mortalidade por homicídio no estado da Bahia, Brasil, no período de 1996 a 2010. Ciência \& Saúde Coletiva, Rio de Janeiro, v. 19, n. 6, p. 1889-1900, 2014.

SPAGNOL, A. S. Jovens delinqüentes paulistanos. Tempo Social, São Paulo, v. 17, n. 2, p. 275-299, 2005.

SPESNY, S. L. A polícia e o crime organizado: o delicado balanço de administrar a vida e a morte no Brasil. Dilemas, Rio de Janeiro, v. 9, n. 2, p. 393-398, 2016.

SPOSATO, K. B.; MATOS, E. L. O. A pedagogia do medo e algumas notas sobre as propostas de rebaixamento da idade penal no Brasil. Dilemas, Rio de Janeiro, n. 1, p. 189-203 2015. Edição especial.

SUDÁRIO, S.; ALMEIDA, P. C.; JORGE, M. S. B. Mulheres vítimas de estupro: contexto e enfrentamento dessa realidade. Psicologia \& Sociedade, Belo Horizonte, v. 17, n. 3, p. 80-86, 2005.

SZWARCWALD, C. L. et al. Desigualdade de renda e situação de saúde: o caso do Rio de Janeiro. Cadernos de Saúde Pública, Rio de Janeiro, v. 15, n. 1, p. 15-28, 1999.

TAKEITI, B. A. A produção de conhecimento sobre juventude(s), vulnerabilidades e violências: uma análise da pós-graduação brasileira nas áreas de psicologia e saúde (1998-2008). Saúde e Sociedade, São Paulo, v. 24, n. 3, p. 945-963, 2015. 
TAVARES, G. M. et al. Análise do clamor por punição e redução da idade penal. Psicologia \& Sociedade, Belo Horizonte, v. 29, p. 1-10, 2017.

TAVARES, G. M.; MENANDRO, P. R. M. Atestado de exclusão com firma reconhecida: o sofrimento do presidiário brasileiro. Psicologia: Ciência e Profissão, Brasília, DF, v. 24, n. 2, p. 86-99, 2004.

TAVARES, R. et al. Homicídios e vulnerabilidade social. Ciência \& Saúde Coletiva, Rio de Janeiro, v. 21, n. 3, p. 923-934, 2016.

TEIXEIRA, C. P. De "coraçôes de pedra" a "coraçôes de carne": algumas consideraçôes sobre a conversão de "bandidos" a igrejas evangélicas pentecostais. Dados, Rio de Janeiro, v. 54, n. 3, p. 449-478, 2011.

O testemunho e a produção de valor moral: observaçôes etnográficas sobre um centro de recuperaçãa evangélico. Religiäo \& Sociedade, Rio de Janeiro, v. 36, n. 2, p. 107-134, 2016.

TEIXEIRA, M. C. S.; PORTO, M. R. S. Violência, insegurança e imaginário do medo. Cadernos Cedes, Campinas, v. 19 , n. 47 , p. 51-66, 1998.

TEIXEIRA-FILHO, F. S. et al. Tipos e consequências da violência sexual sofrida por estudantes do interior paulista na infância e/ou adolescência. Psicologia \& Sociedade, Belo Horizonte, v. 25, n. 1, p. 90-102, 2013.

TELLES, V. S. Prospectando a cidade a partir de suas margens: notas inconclusas sobre uma experiência etnográfica. Contemporânea, São Carlos, v. 3, n. 2, p. 359-373, 2013.

TELLES, V. S.; HIRATA, D. V. Ilegalismos e jogos de poder em São Paulo. Tempo Social, São Paulo, v. 22, n. 2, p. 39-59, 2010.

TOLEDO, L.; GONGORA, A.; BASTOS, F. I. P. M. À margem: uso de crack, desvio, criminalização e exclusão social: uma revisão narrativa. Ciência \& Saúde Coletiva, Rio de Janeiro, v. 22, n. 1, p. 31-42, 2017.

TOMASI, L. O.; MACEDO, M. M. K. Adolescência em conflito com a lei: a intensidade da história de vida em ato. Psicologia: Teoria e Pesquisa, Brasília, DF, v. 31, n. 1, p. 53-63, 2015.

UNITED NATIONS OFFICE ON DRUGS AND CRIME. Global study on homicide 2013: trends, contexts, data. Vienna: United Nations Office on Drugs and Crime, 2013.

VARGAS, E. V. Uso de drogas: a alter-ação como evento. Revista de Antropologia, São Paulo, v. 49, n. 2, p. 581-623, 2006.

VARGAS, J. D. Familiares ou desconhecidos? a relação entre os protagonistas do estupro no fluxo do Sistema de Justiça Criminal. Revista Brasileira de Ciências Sociais, São Paulo, v. 14, n. 40, p. 63-82, 1999a.

Indivíduos sob suspeita: a cor dos acusados de estupro no fluxo do sistema de justiça criminal. Dados, Rio de Janeiro, v. 42, n. 4, p. 729-760, 1999 b. 
Análise comparada do fluxo do sistema de justiça para o crime de estupro. Dados, Rio de Janeiro, v. 50, n. 4, p. 671-697, 2007.

O programa Liberdade Assistida em Belo Horizonte. Educação \& Realidade, Porto Alegre, v. 33, n. 2, p. $147-162,2008$.

Em busca da "verdade real": tortura e confissão no Brasil ontem e hoje. Sociologia \& Antropologia, Rio de Janeiro, v. 2, n. 3, p. 237-265, 2012.

VARGAS, J. D.; RODRIGUES, J. N. L. Controle e cerimônia: o inquérito policial em um sistema de justiça criminal frouxamente ajustado. Sociedade e Estado, Brasília, DF, v. 26, n. 1, p. 77-96, 2011.

VARGAS, J. H. C. Apartheid brasileiro: raça e segregação residencial no Rio de Janeiro. Revista de Antropologia, São Paulo, v. 48, n. 1, p. 75-131, 2005.

VASCONCELLOS, F. B. A família, a violência e a justiça: conflitos violentos familiares, Lei Maria da Penha e concepções jurídicas no Tribunal de Justiça do Rio Grande do Sul. Civitas, Porto Alegre, v. 13, n. 1, p. 136-153, 2013.

VASCONCELOS, F. T. R. As ciências sociais e a violência urbana no Rio de Janeiro. Dilemas, Rio de Janeiro, v. 6, n. 1, p. $127-165,2013$.

As ciências sociais brasileiras e a formação do "campo da segurança pública". Revista Brasileira de Sociologia, São Cristóvấo, v. 5, n. 9, p. 33-58, 2017.

VELHO, G. Individualismo, anonimato e violência na metrópole. Horizontes Antropológicos, Porto Alegre, v. 6, n. 13, p. $15-29,2000$.

VENSON, A. M. Tráfico internacional de pessoas para exploração sexual? uma análise de processos-crime (1995-2012). Estudos Feministas, Florianópolis, v. 25, n. 2, p. 571-591, 2017.

VENTURI, G. Consumo de drogas, opiniấo pública e moralidade: motivaçôes e argumentos baseados em uso. Tempo Social, São Paulo, v. 29, n. 2, p. 159-186, 2017.

VERGNE, C. M. et al. A palavra é... genocídio: a continuidade de práticas racistas no Brasil. Psicologia \& Sociedade, Belo Horizonte, v. 27, n. 3, p. 516-528, 2015.

VERÍSSIMO, M. A nova lei de drogas e seus dilemas: apontamentos para o estudo das formas de desigualdade presentes nos interstícios do ordenamento jurídico-penal brasileiro. Civitas, Porto Alegre, v. 10, n. 2, p. 330-344, 2010.

VIANNA, A. A guerra das mães: dor e política em situaçốes de violência institucional. Cadernos Pagu, Campinas, n. 37, p. 79-116, 2011.

VICENTIN, M. C. G. Corpos em rebelião e o sofrimento-resistência: adolescentes em conflito com a lei. Tempo Social, São Paulo, v. 23, n. 1, p. 97-113, 2011. 
VIEIRA NETTO, M. F.; DESLANDES, S. F. As Estratégias da Saúde da Família no enfrentamento das violências envolvendo adolescentes. Ciência \& Saúde Coletiva, Rio de Janeiro, v. 21, n. 5, p. 1583-1596, 2016.

VILLELA, L. C. M. et al. Tendência da mortalidade por homicídios em Belo Horizonte e regiáo metropolitana: 1980-2005. Revista de Saúde Pública, São Paulo, v. 44, n. 3, p. 486-495, 2010.

WERNECK, A. Uma sociologia da compreensão a partir do par crítica e jocosidade. Civitas, Porto Alegre, v. 16, n. 3 , p. 482-503, 2016.

WIEVIORKA, M. O novo paradigma da violência. Tempo Social, São Paulo, v. 9, n. 1, p. 5-41, 1997.

WILSON, J. O crime pelo rádio. Lua Nova, São Paulo, n. 3, p. 80-84, 1984.

ZALUAR, A. Exclusão e políticas públicas: dilemas teóricos e alternativas políticas. Revista Brasileira de Ciências Sociais, São Paulo, v. 12, n. 35, p. 1-20, 1997.

Oito temas para debate: violência e segurança pública. Sociologia, Problemas e Práticas, Lisboa, n. 38, p. 19-24, 2002.

. Agressão física e gênero na cidade do Rio de Janeiro. Revista Brasileira de Ciências Sociais, São Paulo, v. 24, n. 71, p. 9-24, 2009a.

. Pesquisando no perigo: etnografias voluntárias e náo acidentais. Mana, Rio de Janeiro, v. 15, n. 2, p. 557-584, 2009b.

. A abordagem ecológica e os paradoxos da cidade. Revista de Antropologia, São Paulo, v. 53, n. 2, p. 611-644, 2012a.

Juventude violenta: processos, retrocessos e novos percursos. Dados, Rio de Janeiro, v. 55, n. 2, p. 327-365, 2012 b.

ZALUAR, A.; BARCELLOS, C. Mortes prematuras e conflito armado pelo domínio das favelas no Rio de Janeiro. Revista Brasileira de Ciências Sociais, São Paulo, v. 28, n. 81, p. 17-31, 2013.

ZALUAR, A.; NORONHA, J. C.; ALBUQUERQUE, C. Violência: pobreza ou fraqueza institucional? Cadernos de Saúde Pública, Rio de Janeiro, v. 10, p. 213-217, 1994. Suplemento 1.

ZALUAR, A.; RIBEIRO, A. P. A. Teoria da eficácia coletiva e violência: o paradoxo do subúrbio carioca. Novos Estudos Cebrap, São Paulo, n. 84, p. 175-196, 2009.

ZANETIC, A. et al. Legitimidade da polícia: segurança pública para além da dissuasão. Civitas, Porto Alegre, v. 16, n. 4, p. e148-e173, 2016.

ZAVERUCHA, J. O pacto pela vida, os tomadores de decisão e a redução da violência homicida em Pernambuco. Dilemas, Rio de Janeiro, v. 8, n. 2, p. 235-252, 2015. 
ZILLI, L. F. O "mundo do crime" e a "lei da favela": aspectos simbólicos da violência de gangues na regiāo metropolitana de Belo Horizonte. Etnográfica, Lisboa, v. 19, n. 3, p. 463-487, 2015.

ZILLI, L. F.; BEATO, C. Gangues juvenis, grupos armados e estruturação de atividades criminosas na Regiāo Metropolitana de Belo Horizonte. Dilemas, Rio de Janeiro, n. 1, p. 73-110, 2015. Edição especial.

ZILLI, L. F.; VARGAS, J. D. O trabalho da polícia investigativa face aos homicídios de jovens em Belo Horizonte. Ciência \& Saúde Coletiva, Rio de Janeiro, v. 18, n. 3, p. 621-632, 2013.

ZUQUETE, J. G. P. E. S.; NORONHA, C. V. "Foi normal, não foi forçado!" versus "fui abusada sexualmente": interpretação dos discursos de agressores sexuais, das suas vítimas e de testemunhas. Physis, Rio de Janeiro, v. 22, n. 4, p. 1357-1376, 2012.

\section{Resumo}

\section{O calcanhar de Aquiles dos estudos sobre crime, violência e dinâmica criminal}

Dois sâo os objetivos deste trabalho: mapear a produção indexada pelos termos "crime", "criminal", "criminalidade" e "violência" nas revistas mais importantes da área da sociologia (aquelas indexadas como A1 e A2 no Qualis da Fundação Capes) e entender quais são os métodos de pesquisa mobilizados nessas análises. De maneira geral, os estudos sobre crime, violência e dinâmica criminal vivenciaram uma crescente incorporação de técnicas de pesquisa qualitativa, com destaque para o uso de etnografias, entrevistas semiestruturadas e observação participante em contextos de violência urbana, tais como favelas nas grandes cidades e prisōes superlotadas. O escrutínio de dados oficiais ou de bancos de dados construídos a partir de surveys está longe de ser o principal substrato empírico para a compreensão das dinâmicas de criminalidade, ficando à frente apenas dos trabalhos que conjugam técnicas quantitativas e qualitativas de pesquisa social. O balanço da literatura indica que o calcanhar de Aquiles da área reside na dificuldade em incorporar metodologias que permitam ir além da descrição do local, de forma a avançar rumo a uma produçấo mais abrangente do contexto nacional.

Palavras-chave: Metodologia, Estudos Quantitativos, Estudos Qualitativos, Métodos Mistos, Criminologia, Estudos Sobre Criminalidade Brasileira.

\section{Abstract}

\section{The Achilles Heel of studies on crime, violence and criminal dynamics}

This study has two objectives: to map the production indexed by the keywords "crime," "criminal," "criminality" and "violence" in the most important journals of sociology (those indexed as A1 and A2 in the Capes Foundation Qualis) and to understand which are the research methods mobilized in these analyses. In general, studies on crime, violence and criminal dynamics have experienced an increasing incorporation of qualitative research techniques, with emphasis on the use of ethnographies, semi-structured interviews and participant observation of contexts of urban violence, such as favelas in large cities and overcrowded prisons. The scrutiny of official data or databases constructed from surveys is far from being the main empirical substrate for the understanding of crime dynamics, being ahead of the studies that combine quantitative and qualitative techniques of social research. The balance of the literature indicates that the area's Achilles heel lies in the difficulty of incorporating methodologies that go beyond the description of the place, in order to move towards a more comprehensive production of the national context.

Keywords: Methodology; Quantitative Studies; Qualitative Studies; Mixed-Methods; Criminology; Brazilian Crime Studies. 


\section{Résumé}

Le talon d'Achille des études sur le crime, la violence et la dynamique criminelle

Il y a deux objectifs : cartographier la production indexée par les mots " crime ", " criminel ", " criminalité » et " violence " dans les revues les plus importantes du champ de la sociologie (ceux indexés à A1 et A2 dans le Qualis de la Fondation CAPES) et comprendre les méthodes de recherche mobilisées dans ces analyses. En général, les études sur le crime, la violence et la dynamique criminelle ont connu une intégration technique croissante de la recherche qualitative, en mettant l'accent sur l'utilisation des ethnographies, des entretiens semi-directif et l'observation participante des contextes de violence urbaine, comme les favelas dans les grandes villes et les prisons surpeuplées. L'examen des données officielles ou des bases de données construites à partir des enquêtes est loin d'être le principal substrat empirique pour comprendre les dynamiques de la criminalité, étant devant seulement des travaux qui combinent des techniques quantitatives et qualitatives de recherche sociale. La littérature indique que le talon d'Achille de ces études est la difficulté à intégrer les méthodes qui permettent d'aller au-delà de la description du terrain, afin de se diriger vers une production plus complète du contexte national.

Mots-clés: Méthodologie; Études Quantitatives; Études Qualitatives; Méthodes Mixtes; Criminologie; Études sur Criminalité Brésilienne. 